Historic, Archive Document

Do not assume content reflects current scientific knowledge, policies, or practices. 


\section{INDEX and GERMINATION TABLE}

WHEN sowing divide the packages and sow at different ti:nes. Note the time, and give good care until the plants have had time to ap-

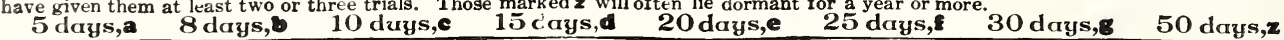

Ab-ro-ni-a

A'-brus

e, 5 Budd-lei'-a

a, 32 Dat-u -ra

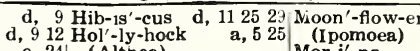

c, 21 Rud beck' i a e,

d, 26 Sal pig los' sis

c, 26 Mor-i'-na Morning Glory

c, 20 Sal' vi a

d, 8 Perennial

a, 1025 Hon'-es-ty

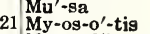

b, 1326 San vi ta'li a

d, 16

Ab-sin'-thi-um
Ac-anth'-us

Ach-ill-e'-a

Ach-i-me'-nes
Ac-on-i -tum

e, 22 Caj-oph'-or-a

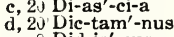

z, 25 Hum-u'-lus

d, 13 Cal-an-dri'-ni-a

8 Did-is'-cus
828 Dig-it-a'-lis

d, 9 Hun-nem-an'-ni-

Ac-roc-li'-ni-um b, 19 Cal-en'-du-la

Ad-lu' $\mathbf{u}^{\prime}$ mi-a

f, 22 Cal'-la

Ad-o'-nis
A-ven'-a

, 5, 22 Cal-lic-ar'-pa

\begin{tabular}{l|l} 
c, 8 & Dim-orph-oth \\
e, 29 & Dip'-sac-us
\end{tabular}

c, 24 Hy-per'-ic-um

Naeg-el'ia

b, Sapo na' ri a

25 Nas-tur'-ti-um b, 2131 Sax' i frag a

c, $\begin{array}{r}c, 16 \\ 1727\end{array}$

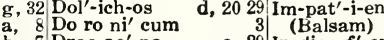

d, 2025 (Peren'l Candytuft) Nem-es'-i-a

Aeth-i-on-e'-ma e, 5 Cal-li-op'-sis

b, 7 Drac-ae'-na

e, 29 In-dig-of'-er-a

Ag-ap-anth'-us

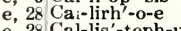

Ag-a'-ve

e, 28 Cal-lis'-teph-us

a, 6 Ec-bal'-li-um

e, 10 In-dig-la

29 Nem-oph'-i -la

a, 13 Sehiz anth'

Ag-e'-rat-um

a, $5 \mathrm{Cal}^{\prime}$-tha

f, 26 Ech-in-o-cys' Ech-ops $^{\prime}$-in-o

e, 21 1-pom-oe'-a
z, 21 I-pom-op'-sis

Ag-rost-em
Ag-ro'-stis

Ag-ro'-stis
Ak-e' - bi-a

Al-kek-eng'-i

Al-on-so'-a
A]-thae'-a

A]-thae'-a

Sax'-a-tile

Am-ber-bo'-a
Am-bros'-i-a

Am-mob -i-um

An-ag-al'-lis

An-chu'-sa

An-gel'-ic-a

An-gel-o'-nia

An'-ise

, 22 Cal-yc-anth'-us

f, $32 \mathrm{E}^{\prime}$-del-weiss

f, 32 E'-del-weiss

d, 25 l'-ris

31 Nic-an'-dra

e, 30 Scu tel la $\mathbf{a}^{\prime} \mathrm{ri} \mathrm{a}^{\prime}$

17
17

a,21 Nier-em-berg'-i-a 13 Sem per vi' vum

e, 25 Ni-gel'-la

e, 25 (Pseudo-acorus)

$\begin{array}{lll}\text { g, 32 Cam-pan'-u-la a, } 823 \text { Ep-i-lo'-bi-um } \\ \text { d, } 16 \text { Can'-na } & \text { d, } 8 \text { Er-e-mu'-rus }\end{array}$

d, 5 Can'-nab-is

d, 8 Er-e-mu'-rus

d, $25 \mid \begin{aligned} & \text { I'-sat-is } \\ & \text { Is }- \text { ol }-0^{\prime}-\text { mat }\end{aligned}$

25 is-ol-o'-ma

3 No-to-bas'-is

31 Nym-phae'-a

e, 29 Oen-oth-e'-ra

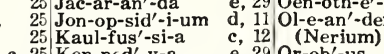

e, 29 Or-ob'-us

, 5, $22 \mathrm{Cap}^{\prime}$-si-cum d, 8 Er-ys'-i-mum

c, 22 Car'-di-nal Climber' 20 Er-yth-ri'-na

, 5 Ipomoéa

$\begin{array}{rll}\text { b, } 5 & \text { Car-di os p } \\ \text { a, } 19 & \mathrm{Car}^{\prime} \text {-du-us } \\ \text { c, } 5 & \mathrm{Ca}^{\prime}-\text { ri-ca }\end{array}$

$\begin{array}{ll}\text { c, } 2 \text { Ken'-il-worth Ivy c, } 12 \text { Ox'-al-is } \\ \text { c, } 10 \text { (Linaria) } & 36 \text { Ox-y-u'-ra }\end{array}$

$\begin{array}{lll}\text { c, } 25 & \text { Ken-ned'-y-a } & \text { e, } 29 \text { Or-ob'-us } \\ \text { c, } 2 & \text { Ken'-il-worth Ivy c, } 12 \mathrm{Ox}^{\prime}-\mathrm{al}-\mathrm{is} \\ \text { c, } 10 & \text { (Linaria) } & 36 \mathrm{Ox}-\mathrm{y}-\mathrm{u}^{\prime}-\mathrm{ra}\end{array}$

25 Pae-o'-ny

c, 5 Car-na'-tion

20 Eu-cal-yp'-tus

c, 29 Kniph-of'-i-a

d, 12 Palms

$32 \mathrm{Pan}^{\prime}-\mathrm{sy}$
$12 \mathrm{Pap}-\mathrm{a}^{\prime}-\mathrm{ver}$

, 2529 Ko-el-reu-te' ${\text { Kal-lem-an } t^{\prime}-\mathrm{i}-\mathrm{a}}^{-a}$

1029 Eu-phor'-bi-a

e, 10 Lan-ta'-na

g, 19 Cat-an-anch'-e

d, 3 Eu-toc'-a

d, 5 Cat-al'-pa

d, Fenz'-li-a

c, 10 Lap-a-ge'-ri-a

d, 30 (Poppy)

d, 12 as-sif-lo'-ra

b, 13 Sen' si tive

a, 27

$\begin{array}{lll}\text { An-ten-na'-ri-a } & \text { f, } 3 \text { Silene Armeria } \\ \text { Anth'-em-is } & \text { a, 5 22 Ce-lo'-si-a } & \text { c, E Foe-nic'-u-lum } \\ \text { For-get'-me-not }\end{array}$

Anth'-em-is

, 10 Lark'-spur

c, 13 Mimosa.

c, 13 Si le' ne

1326 Sin' ning i

d, 27

f, 30 Smi Sminia $^{\prime}$

13 Medeola

c, 3

c, 26 So lan' dra

d, 30

Anth-oum d, 18 Cent-autis

\begin{tabular}{ll|l} 
Anth-ox-anth'um d, 18 Cent-au-rid'-i-um c, 8 & Fra-ga'-ri-a \\
An-tig-o'-non e, 28 Cen-tran'-thus b, \& Fran-co'-a
\end{tabular}

b, \& \begin{tabular}{l|l} 
Fran-co' $-\mathbf{a}$ \\
d, 8 Frees'-i-a
\end{tabular}

Aq-uil-e'-gi-a

c, 5. Cen-tro-se'-m

b, 24 Fuch'-si-a

Ar-but'-us

a, 22 Ce-rin'-the

c, 8 Funk'-i-a

Are-to' -tis

g,.32 Chae-nos'-tom-a c, 8 Gail-lar'-di-

Ar-gem-o'-ne

d, 6 Cheir-anth'-us c, 82431 Gam-o-lep'-is

Ar-me'-ri-a

Ar-ne'-bi-a.

2832 Wallflower

As-cle'-pi-as

b, 6 Chrys-anth

a, 2: $\begin{aligned} & \text { Gar de' ni a } \\ & \text { Gar-do'-qui-a }\end{aligned}$

e, 1326 Lav-a' -ter-a

f, 2125 Pea, Sweet

a, 13 Sol i da' go

e, 1731

z, 26 Sper' gul a ri a

b, 3

c, 14 Stat' ic e

c, 26 Sten ac' tis

d, 1632 Ste $^{\prime}$ vi a

r, 30 Stach' ys

e, 32 Stocks

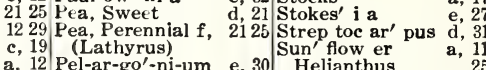

f, 1025 Lav'-en-de

e, 29 Lep-tos'-iph-on

12 Punt-ni-um

e, 30 Sun' flow er

a, 17

d, 27

ge 31

z, 29 Leu-canth'em-um 1225 Pet-u'-ni-a

d, $25 \mathrm{Li} \mathrm{a}^{\prime}$ tris $26 \mathrm{Phac}^{-\mathrm{el}^{\prime}-\mathrm{i}-\mathrm{a}}$

e, 10 Lig-ul-a'-ri-a

a, 25 Lil i-um

c, 10 Lim-nanth'-es

$\begin{aligned} 3 & \text { Lin-a'-ri-a } \\ \text { cin-um } & \\ \text { Lin um } & \end{aligned}$

, 25 Phas'-e-o-lus $^{\prime}$

1626 Suth $\in r$ land' $i$

a, 11

As-per'-u-la

g, .28 Cir'-si-um

d, 2* Gen-ti-an'a

c, 10 Lo-a'-sa

d, 12 Phlox Drum

1530 Sweet Wil'

c, 16 Dianthus Barbatus

d, 20 'Tac so' ni a

a, 31

b, 1226 Phy'-sal-is

, 15 Marigold

c 31

Chy-sos-teg'-i-a 25 'The' 1126 '

e, 25 Luf'-fa

e, 30 Lu-na'-ri-a

Aerennial

As-til'-be
At'-rip-lex

At'-rip-lex
Au-bri-e'-ti-a

b, 62 Cle $\mathrm{Cle}^{\prime}-\mathrm{mat}-\mathrm{is}$

d, 22 Clin-to'-ni-a

z, 24 Pelargoniu

11 (Honesty)

a, 99 Ger-be'-ra

c, 29 29 (Perennial)

e, 6 Cli-to'-ri-a

e, $20 \mathrm{Ge}^{\prime}$-um

b, 25 Lych'-nis

e, 22 Cob-ae'-a

d, $20 \mathrm{Gil}^{\prime}-\mathrm{i}-\mathrm{a}$

c, 3 (Perennial)

Aur-ic'-u-la

c, 18 Col'-e-us

c, 929 Glad-i'-o-lus

16 Lyth'-rum

Balm [Herb]

Bal'sam

Bap-tis'-i-a

Bar-to'-ni-a

Beg-o'-ni-a

$\mathrm{Bel}^{\prime}$-lis

b, 7 29 Com-me-li'-na

b, 8 Glau'-ci-um

d, 11 Mal-col'-mi-a

g, 30 Con-vol'-vul-us 92029 Glox-in'-i-a

c, 25 (Virginia Stock)

d, $29 \mathrm{Ma}^{\prime}$-lop-e

7 Cos-mid'-i-um

b, 924 God-.'-ti-a

d, 11 (Perennial)

f, $19 \mathrm{Cos}^{\prime}-\mathrm{mos}$

$\begin{array}{ll}\text { a, } 9 & \text { Gom-phre } \\ \text { a, } 8 \text { Gourds }\end{array}$

c, 19 Mar'-i-gold

d, 28 Cox'-comb

Ben-in-ca'-sa

a, 20 Crat-ae'-gus

Gram-man'-thes

21 (Climbing)

32 Gym'-noth-rix

3. Mam-mil-la'ri-a

g, $32 \mathrm{Cre}^{\prime}$-pis

a, 9 Gyp-soph'-il-a c, 1925 Man-de-vil'-le-a $_{\text {Car-den-ber'-gi-a }} 29$ Mar-tyn'-i-a

$\mathrm{Be}^{\prime}-\mathrm{ta}$, Beet

Big-no'-ni-a

Boc-co'-ni-a

Bol-to' - ni-a
Bon-a-nox'

Ipomoea

Bor- $\mathrm{a}^{\prime}-$ go

Bor'-e-cole

Brach-yc'-om
Bra'-he-a

Bri'-za

Brom'-us

Brow-al'-li-a

Bry-o-nop'-sis

c, 7 Crue-i-an-el'-la

z, 29 Cuc-ur'-bit-a

z, 23 Cuc-ur'-bit-a

c, 21 Cy'-clam-en

Cy-clan-the' -
Cy-don'-i-a

9 Kennedya

29 Mar-tyn'-i-a

d, 21 Pic'-o-tee

26 Pink

12 Pit-tos-por'-um

26 [Wahlenbergia]

c, 12 Pod-ol'-e-pis

d, 26 Poin-ci-an'-a

31 Pol-em-o'-ni-um

17 Pol-yg' - o-num

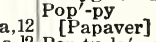

a,12 Por-tu-la'-ca

a, 13 Prim'-u-la

31 'tar'-mic-a

Pu-er-a'-ri-a

e, 12 Pyr eth' rum

a, 13 Ra nun' cu lus

21 Res $\mathrm{e}^{\prime}$ da

e, 26 [Mignonette]

,29 Mau-ran'-dy-a

, 25 Me-con-op'-sis

b, 29 He-dys'-ar-um

f, 29 Hel-en'-i-um

e. 20 He-li-anth'-em-um

, 25 Mel-i-anth'-us

25
11
25
Mign-on-ette'
(Reseda) a, 13 Rhod an' the

c, 7 Cyn-o-glos'-sum a, 9 Perennial $\quad 25$ (Reseda)

f, 31 Cy'-press vine $\quad$ a, 21 He-lich rys'-sum a, 19 Mi-mo'-sa

d, 18 Ipomoea quamoclit $\mathrm{He}^{\prime}-$ li-o-trope

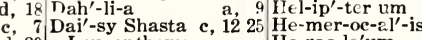

d, $29 \mathrm{Mi}^{\prime}-\mathrm{na}$

d, 19 Mi-ra-b'-i-lis

Mol-u cel'-la 


\section{The Best VEGETABLES for General Use}

Articho'se, French Green Globe, perennial; edible heads. 5c. |Kale, Dwf. Scotch, showy; hardy, for winter greens. 5 cts. Asparagus, Mary Washington, new rust-proof, best of all. 5c Bean, Early Mazagan Lnglish Bean, upright, Lima flavor.5c.

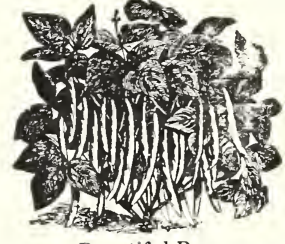

Bountiful Bean

Bean, Bountiful. Earliest, best snap bean, bears ncarly all season. Entirely stringless. Better than Stringless Green Pod. Finest flavored, most tender, surpassingly productive. Pkt.5cts. 1-2 lb. 20 cts.. 1 lb. 35 cts.

Improved Golden wax, best, most productive wax bean. Pkt. 5 cts., 1-2 lb. 20 cts., 1 lb. 35 cts.

ular climber; green pods 8 in. long, stringless when young, clustered, very productive. Pkt. 5cts., 1-2lb. 20 cts., 1lb. 35c. Striped Creaseback, flowers rich rad; pods 9in. long, green, round, full, productive; best corn-field. 5c. 1-2lb. 20c. 11b. 35c Lima bean, Fordhook Bush, 18 in., most grown of Limas; fine flavor $\approx$, very productive. 5cts. 1-2lb. $20 \mathrm{cts}$. 1lb. $35 \mathrm{cts}$.

Carpenteria, best vine Lima; tinest quality, productive. 5cts.

Beet, Early Wonder, ideal in form, color, flavor; early. oc. oz.10 Detroit Dark Red,Early, shapely,s weet,tender;excels. 5 c. oz10 irocoli, Michaelmas, like Cauliflower; easier grown, finer flavored, more tender than Cabbage. Pkt. 5cts.

Brussels Sprouts, Improved Half Dwarf; smaii, solid Cabbagelike heads upon an erecs stem; tender, delicious. $5 \mathrm{c}$.

Cabbage, Early Jersy Wakefield, earliest, solidest, best of earlies; sure to head. Pkt. 5cts. 1-2oz 20

Late Flat Dutch, unexcelled for full crop, sure to head, large, solid, ninest quality; amazingly productive, even in bad seasons,!keeps well. Pkt. 5cts. 1-2oz. 20cts. All Seasons, heads round, weighs $12 \mathrm{lbs}$. rich quality; sure to head. 5cts. $1-20 \mathrm{z} .20 \mathrm{c}$ Red vutch, deep red,fine for pickling. 5 cts. Perfection Drumhead Savoy, of easiest culte Flat Dutch crinkly heads, sweet, rivals Cauliflower. 5c., 1-2 oz. 20c. Cardoon, Large Smooth, best sort, fleshy. 5cts. 1-2oz. 15cts. Carrot, Danvers Improved, fine orange-red, 5c, oz. 20cts. Cauliflower, Snowball, early, sure to head, fine quality. 5c s. Danish Giant, a Dry Weather Cauliflower, easily grown as cabbage, large, solid white heads, a week later than Snowball, heads when othe $s$ fail, quality equal to Snowball.5c.

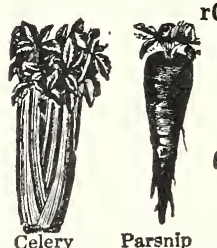
rCelery, Golden Self-blanching, early,' dis ease-resistant, handsome, rich-flavor. $d$, keeps well; a splendid celery. 5c. 1-2oz.20 Giant Pascal, Winter King,late,large, solid,thick, stringless, heart golden yellow, very fine. Pkt. 5c. 1-2 oz. 20c.

Collards, True Grorgia, stands out, use as needed, $5 \mathrm{c}, 1-2 \mathrm{oz} .10 \mathrm{c}$.

Georgia White, headslike Cabbage;never Parsnip winter-kills; leave headsin bea till needChives, onion-like; without bulbs; tops used. $5 \mathrm{c} .1-2 \mathrm{oz} .20 \mathrm{c}$. Chicory, Large-rooted, dry and use as coffee. 5c. 1-2 oz. 10c. Corn, Early Mayflower, earliest; bears 2 large ears. 5c.1-2lb 20 Golden Bantam, second early, sweet, prolific, 5c. 1-2 lb. 20c. Country Gentleman, next in order, sweetest, $5 c$ 1-2lb, 20cts.

Kendell's Early Giant, the best all-round Sweet

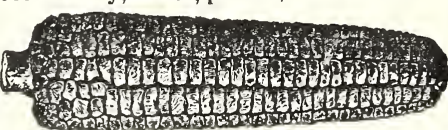

Kendell's Giant

Kohl Rabi, E. White Vienna, tender, prolinc; 5cts. 1-2 oz. 10 c. Leek, American Flag, easily grown, popular sort. 5c,1-2 oz 15 Lettuce, Curled Simpson, finest leaf Lettuce; rich, tender. 5cts, $1-2$ oz 10 cts. Big Boston,extra,sum'r or fall;5c 1/20z10 Iceberg, heads, finest quality; 5 cts.

Hot Weather, the best all-round Let= tuce. - Heads large, firm, well blanched,sweet, buttery, of finest flavor,stands hot weather best, and is also best for winter, enduring cold that would de- Hot Weather Lettuce stroy others. It's a "seek-no-farther".5ets, 1-2 oz 10cts. New York, huge heads, fine quality, easy grown; $5 c, 1-2$ oz10c Paris White Cos.,a delicious sort, none better; $5 c, 1 \cdot 20 z 20 c$ Muskmelon, Emerald Gem, early, sweet, fine; 5c 1.2 oz 10乞. Rocky Ford, most popular of all, sweet, rich; $5 \mathrm{c} 1-2 \mathrm{oz} 10 \mathrm{c}$. Market King, huge in size, fleshy, vely sveet; $5 \mathrm{c} 1-2$ oz $10 \mathrm{c}$ Water Melon, Kl€ckley Sweet, the sweetest, most suie, most prolific of all; get Kleckly for one melon: $5 c, 1-2$ oz 10 cts. Coles Early, earliest, very sweet and productive; $5 \mathrm{c}$, oz $10 \mathrm{c}$. Irish Gray, very large, sugary; best shipper; 5cts. oz 10cts.

Mustard, Giant Plume, huge, plumy, tueautiful; 5c. cz 10cts.

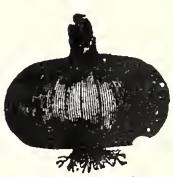

Ailga Craig Onion, Danvers Yellow Globe, fine, productive, sown early matures filst seascn; $5 c, 1 / 20 z 15$ Australian Brown, early, mild, fine; $5 c, 1 / 2$ oz 15 Southport Globe,large,mild,keeps; 5c,1-4oz15 Ailsa Craig, largest of Onions, glolular, fine grained,mild,sweet,best keer er. Start early and transplant, very productive, fine for exhibition, cultivate wall. 5cts, $1-2$ oz $10 \mathrm{cts}$. ' Whito Portugal, best, silver-skin, fine for plckles; $5 \mathrm{c}, 1 / 20 \mathrm{o} 10 \mathrm{c}$ Okra, Brunswick, ncw, very productive, pods long, tender, of excellent flavor, the best variety; 5cts, oz $10 \mathrm{cts}$.

White Velvet, distinct, large, tender; 5cts, oz. 10cts.

Parsnip, Hollow Crown, smooth, long, prolific; $5 \mathrm{c}, 1-2 \mathrm{oz} 10 \mathrm{c}$. Parsley,New Crested Gem, finest Parsley; see pg.16. 5c,1/20z 10c

Pea, Model Extra Early. yields an enormous crop 50 days after planting, pods enclosing eight big peas, tender, sweet; plants 18in. high,need no support,yields two or three crops, bears in summer when others fail; best extra early Pea; 5c, 1-2lb 30c. Laxtonian, medium early, unsuported vines 18in., a mass of huge pods bearing big,sweet luscious peas, none better, none more productive; a great Pea; 5cts. 1-2ih 25cts.

Cheiftain, new, best of all Peas for quantity and quality; 2ft., loaded with a wealth of giant pods swelied with huge sugary Peas, ripens after

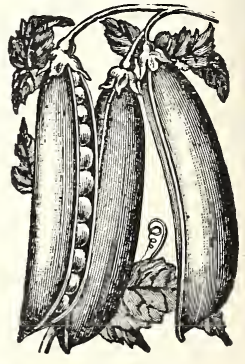

Laxtonlan

Laxtonian, finest for table, mark et or exhibition: 5c.1-2lb 25 Other Peas: Alaska, Little Marvel, Telephone, Potlach, Giant Melting Sugar, White Marrowfat; 5 cts. 1-2lb 25cts.

Pepper, Neapolitan, Red Chili, Chinese Giant; each 5cts.

Pumpkin, Conn. Field, large, productive, for stock; $5 \mathrm{c}$, oz 10c Large Cheese, fine quality to cook. keeps well; 5cts, oz 10cts Radish, We supply French Breakfast, Early Long Scarlet, Whita Icicle, Chinese Winter; 5 cts. pkt, 1-2 oz $10 \mathrm{cts}$.

Salsify, Giant L. Island, Veg. Oyster for soup; $5 \epsilon, 1-2 \mathrm{oz} 15 \mathrm{c}$. Spinach, King of Den mark, long, standing, best; $5 \mathrm{c}, 1-2 \mathrm{oz} 10 \mathrm{c}$ New Zealand, can be used all summer; Pkt 5c, 1-2 oz 10c.

Squash, Boston Marrow, Hubbard, Giant Summer Crookneck, Fordhook, Swiss Chard Lucullus; each, per pkt 5c, 1.20z 10c Tomato, Spark's Earliana. 3in, across, solid, tasty. prolific, smooth, disease-free, ripens evenly, no core; 5 c. 1.2 oz 20 Ponderosa, largest, solidest, best to slice: $5 \mathrm{cts}, 1-8 \mathrm{oz} 15 \mathrm{cts}$. Golden Queen, large, rich, golden yellow; 5cts, 1-8 oz 15cts. Turnip, Early White Milan, earliest, tender, fine: $5 c$, oz $10 \mathrm{c}$. Purple-top White Globe, large, best main crop; $5 \mathrm{cts}$, oz $10 \mathrm{c}$. American Purple-top Rutabaga, the best Swede; 5c, oz 10. Snowball, extra early, and best, also for late crop and winter greens; delicious, very productive; pkt 5 cts, oz 10 cts.

We offer the best select Vegetables, and our seeds are of the best quality. Fou will not err in giving us your order, You are sure of getting the best in both quality and vitality. 


\section{PARKS' CHOICE}

\section{Dependable Flower Seeds}

\section{Part I: Garden Flowers Blooming the First Season.}

\section{ANTIRRIINUM, Finest Giant Fragrant Kinds}

Complete Special Mixture of these superb Snapdragons, 5 cts.

\section{T} HINUMS or SNAPDRAGONS we offer will be a revelation to many of our friends. The flowers, disposed in big spikes, are of great size, and display the richest and most novel culors and variegations. The plants are glorious in either beds or pots, and are easily started. We highly recommend our Snapdragons.

Finest varieties of Giant-f1'vd Tall Jnapdragons Brilliant Rose, a rich color. Canary Bird, canary yellow. Cardinal, brilliant scarlet. Cattleya, rosy lilac.

Golden Queen, rich golden yellow. Gotelind, copper, rose throat. Maralla, copper-carmine.

Purple King, velvety dark purple Ruby, pure ruby color.

Snowflake, lorely pure white.

The Rose Improved, exceptionally large fls; salmon-rose with golden yellow center; very choice. All Giant-flowered Tall Sorts in our superb mixture, 5 cts. Finest varieties of Giant I'vid Semi-dw'G Snapdragons Albino, delicate shades, flushed. Bonnie Lass, rose, white throat. Matchless, bright buff, gold cent'r. Bright Rose, charming pure rose. Mauve Beauty, lovely rosy-mauve Carmine Queen, rich rose-carmine Pink and Terra-cotta Shades, a Golden Monarch, gelden yellow. new class of art shades. Madonna, fine, large-flw'd white; Scarlet King,large glowing scarlet good compact habit; exquisite. Tîe Bride, jure white, fine to cut. Fine Special Mixture of these Superb Semi-dwarf varieties, many of which have been given an Award of Merit by the Royal Hort. Society of England. Tom Thumb. These Snapdragons form little bushes 6 inches high literally smothered with bright bloom. Fine for either beds or pots. Colors: White, Rose, Orange, Striped. Vermilion, sep. or mixed

Benary's New Double, direct from Mr. Benary, including white, rose, yellow, variegated, etc. in mixture only.

Picturatum, a beautiful variegated class showing art shades and vivid colors in pleasing mixture.

ABRONIA umbellata, 1ft. Sand Verbena, beautiful, big, vivid rosy-pink umbels. Thrives in a sandy, sunny bed.

ADONIS æstivalis, Ift, deep red, flat petals, opening wide.

Autumnalis, 18 in. bushy; fls small, red, concave petals.

Ageratum. Ever-blooming annuals, fine for beds, edgings and pots; easily grown; like good soil and a sunny situation. The lovely blue and white clusters literally cover the plants throughout the season; very beautiful plants.

Conspicuum, 4ft. white clusters; Lasseauxii, 1ft. mauve; both fiae for cutting; both can be grown in pots in greenhouse. Little Dorritt, 6in. Azure blue; also White, both flne. Imperial Dwarf, 8in. Blue; also White, splendid bedders. Swanley Blue, 1ft. large, charming; also Blue Perfection. Little Blue Star, 4in. compact; numerous small blue fls. Mauve Beauty, 6in. compact, large mauve fls; splendid. Victoria, 6in. light blue with white center; beautiful. Mexicanum, 2ft. Blue; also White; fine for beds.

Blue Bell, new, the best true biue Ageratum; beautiful. Complete Special Mixture of the above Ageratums, 5 cts.

AMARANTHUS, very ornamental, easily grown plants for foliage and flowers. We have the finest kinds, separate or mixed. A mixture affords a great variety, and is a source of wonder and pleasure.

Abyssinicus, $5 \mathrm{ft}$. red, fine.

Amabilis, $3 \mathrm{ft}$. rose, gold, fiery red.

Bicolor ruber, $3 \mathrm{ft}$. rich scarlet.

Coleifolius, new, Firebrand.

Cruentus, Prince's Feather, red. Love Lies Bleeding, red, select. Melancholicus ruber, fine red. Monstrosus, $3 \mathrm{ft}$. dark blood red. Salicifolius, $2 \mathrm{ft}$. tops deep red.

Tricolor, Joseph's Coat, Improved. Aurora, 3ft. red, yellow, green with vivid carmine head.

Gigantea, 6ft. rich colors; fine.

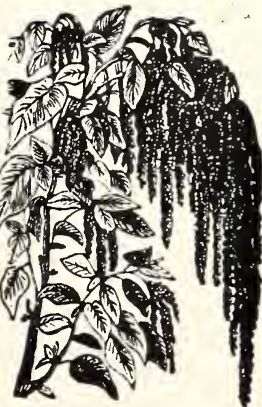

Love Lies Bleeding
Complete Special Mixture of Amaranthus, 5 cts.

Note. Our sceds of Love Lies Bleeding were saved from Special Stock, producing $\theta$ xtra long drooping red clusters.
ETHIONEMP Buxbaumii,6in, red,in racemes,pretty, profuse AGROSTEMMA coli-rosa Kermesina, $1 \mathrm{ft}$. grown in masses this is a showy and beautiful annual; known as Rose of Heaven; rich crimson; free-blooming.

Coli-rosa, Mixed; all the fine colors in superb mixture.

ALONSOA, $1 \mathrm{ft}$. to $2 \mathrm{ft}$. beautiful, free- and continuous-blooming plants for beds or pots; easily grown, and should be better known. We offer the following superb kinds:

Albiflora, white; Grandiflora, vermilion; Chamois: Linıfolia. scarlet; Linifolia gracilis, charming; Mutisi, rose with scarlet center; Myrtifolia, large scarlet; Warscewiczii compacta. brilliaut red, for pots. These sorts in Complete Mixture, $5 \mathrm{c}$. ALTHEA semperflorens, 6it. Annual Double Hollylock, blooming first season. Plain Double in splendid mixture, $5 \mathrm{c}$. Fringed Double in splendid mixture, $5 \mathrm{cts}$. Plain and Fringed Double Mixed, 5 c, Our seeds are of finest quality.

ALYSSUM, Sweet, 6in. everblooming annuals well adapted for beds or borders, blooming continuously throughout the season. Fine also for pots. Common White, 1-4 oz. $10 \mathrm{c}$. Little Gem, white; Lutescens, yellowish; Carpet of Snow white; Lilac Queen, lilac; Minimum, select white; Little Dorritt, white; Procumbens, creeping, white.

Note. Sweet Alyssum is one of our most beautiful and desirable annuals. You can hardly "keep house" without it. Don't fail to get a packet or two of our improved kinds. AMBERBOA muricatå rosea, 2ft. pink; fine for cutting. AMBROSIA mexicana, 2ft. pretty fragrant.fern-like foliage. ANAGALLIS, Pimpernel, $1 \mathrm{ft}$. charming dwarf annuals for pots, beds and édgings. We offer Scarlet, Flesh, and Blue, separate or in fine special mixture of all colors.

ANCHUSA Capensis, 2ft. azure blue fls in clusters, similar to For-get-me-not; showy in a bed or border; good to cut. Affinis, $4 \mathrm{ft}$. azure blue; attractive and handsome.

Sempervirens, $3 \mathrm{ft}$. light blue; very beautiful.

Barrelieri, $3 \mathrm{ft}$. dark blue; Dropmore, $4 \mathrm{ft}$. large, pure gentian-blue, fine for cutting. See page 22.

A NGELONIA grandiflora, 3ft. lilac, tigred throat, fragrant. ANTHEMIS Kelwayi, 2ft. splendid golden yellow; fine to cut. Kelwayi White, like the preceding but white flowers.

Nobilis, 13in. spreading, white; for beds and for cutting. Tinctoria, Golden Marguerite, $2 \mathrm{ft}$. fine for beds and cut'cing. 


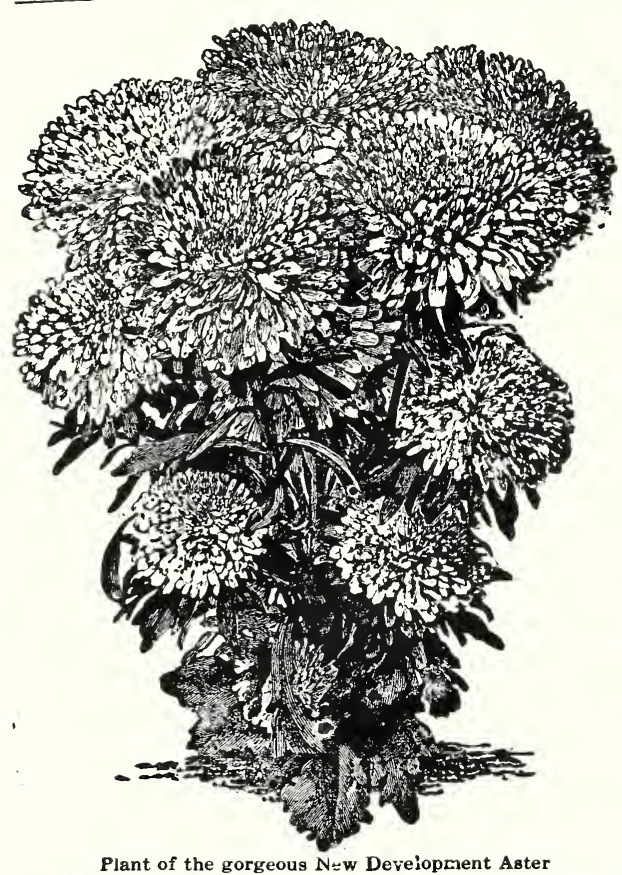

Plant of the gorgeous $\mathrm{N}=$ w Development Aster

Paeony-\&lowered Perfection, an incurved Aster,very large and full; one of the most bcautiful for either beds or eut flowers. Colors: White Red white edge, Old Rose, Deep Blue, White, Rose and white; sep. or mixed; also Hors, Sunfight velllow.

Comet Glant, superb class, the petals twisted giving the big double howers a fluffy globular form; splendid for beds and fine for cutting. Colors: Pure White, Rose, Azure Blue, Dark Blue, Light Blue, Cinnabar Red, Crimson, Jesrlet, Canary, Salmon-rose, White tinted rose, White tinted lilac, Flesh, Pink; separate
or mixed; also Triumph of Paris, white with large yellow center.

Ostrich Plume, a very floriferous aster. the flowers large and plumey with long petals, and produced on long stems; showy in beds and excellent to cut. Colora: Improved White, Crimson, Rose, Light Blue, Lilac, Csnnabar, Salmon-pink, Dark Scarlet, White changing to rose; separate or mixed.

New Mammoth Aster, seeds direct from German Specialists. We highly recommend this New German Aster, and believe it will afford amazing results to those who grow It. Our seeds will not only grow, but will yield among the largest, most double and most beautiful flowers of the Aster family. By all means, add this glorious aster to your list. Colors: Sulphur Yellow, Lilac, Salmon-rose, Rose, Crimson, White and Rose, Flesh; sep or mixt. W s. Here is the description from the German specialists who gr 3 our seeds: "This is considered the gral.dest Aster ever introduced. Piant tall-growing, branching, and bearing flowers of mammoth size, measuring up tu eig at in ches across, densely double, fine curle and feathery highly rese nbling a big Japanese Chrysanthemum, an which may be cut with stems nearly or quite two feet long, unequa as a cut flower for exh bition, and $\mathrm{V} r \mathrm{ry}$ ffective in beds or groups.
From this description 's this aster not worthy of a trial? 50 to 70 seeds From this description a this aster not worthy of a trial? 50 to
in a pa:k 3 . enou $\mathrm{sh}$ to yield plants for a fine bed, only $5 \mathrm{cts}$.

Eel way Giant Lranchi-18 Aster, seeds direct from Kelway or England. $3 C$ in. high, earing full-double flowers five inches \&ross; magnificent and a decided acquisition. Snowstorm, pure white; Splendens, charming pink; Sensation, light lilac Superb, pleasing purple; SparkIe, rich crimson; separate or all in splendid specias mixture.

Giant Crego, full double, huge, 1 ich colors, fluffy petals; mixed. GOLIATH, huge Comet fls; largest and finest exhibition aster.

Eclipse, new Englis' aster; fls curled and crested, fine d'ble; mixt ASTERS, Parks' Superb Double T HE DOUBLE ASTERS are very beautiful annuals for beds, borders and pots. The seeds germinate quickly and the plants thrive in any cin sunny border, aud bloom abundantly throughout the autumn onths, each flower lasting many days. In veds or borders, he plants make a gorgeous display, and if potted when in bud r bloom, they are admirable for room decoration. They are also opular as cuteflowers and well deserve their popularity.

To get the best results, these points should be observed: Get ehoice seed the fimest strains; transplant from the seed box early, giving each plant the il is rich me the small surplus buds and apply liquid fertilizer occasionally as the uds develop. Grown in ruts, the plants, ars prof table for marketing.

We offer seeds of the finest quality, saved by specialists, and they will yield the best results. Be sure to try them.

ifall Double Asters, 2 to 3 st.

AsTzR, New Development, the finest of all Double Asters, developed by Kelways of England, during many years of reful hybridizing and selection. Plants grow two feet high, saring on long stems huge full-double flowers 5 or more inchacross, the florets twisted giving a close resemblance to ne large Japanese Chrysanthemum. This new aster is wonderully effective in beds, and charming for room decoration wher ut. Our seeds are direct from Kelways, and cannot be excelled. Pride of the West, pure white. King of the West, lovely purple. Glory of the West, rich crimson. Beauty ef the West, shell pink. Delight of the West, fine rose. Maid of the West, lavender pink. Grace of the Viest, pale lavender. Queen of the West, azure blue.

uperb mixture of all varieties of New Development Asters, 5c.

Victorla Glant, bears enormous flowers of great fullness, the flat florets charmingly imbricated; one of the most showy and massive of Asters. We offer only the improved lange-flowered Victoria, glorious in beds and fine for cutting. Colors: White, White tinted Rose, Peach Blossom, Crimaon, Fiery Scarlet, Light Blue, Blue, Purplish Violet; separate or in fine special mixture, 5 cts.

American Branching. A superb class of late branching Asters, gorgeous in beds, being very floriferous, and unsurpassed for cutting, having very large double flowers on long stems. Colors: White, Crimson, Light Blue, Dark Blue, Rose, Scarlet, Shell Pink: also Azure Fairy, lovely large azure blue on lon rich ruby ardinal, fine brilliant scarlet; and Heart

Cocardeau or Crown, a very beautiful class, large, double, each flower showing a distinct white center. Colors; Rose, Dark Crimson, Light Blue, Deep Lilac, Dark Blue; separate or mixed.

Ünicum, long, narrow, curled petals; very large, fine double.

Ball's White, new, globular, snow-white fine petalled, large nd very beautiful; good to cut. This is the latest-fiowering of all.

Globe Quilled, Kelway's Perfect Model, the finest strain of Quilled Aster. There is nothing in existence approaching it. The flowers are all berfectly semi-globular, and up to exhibition standard. Certificated by Royal Horticultural Society; Prize and Gold Medal Paris Exposition. Our seeds are direct from Kelway. Mixed only.

Kelway's New Decoration Aster grows $3 \mathrm{ft}$. high, and the enormous double, rich-colored flowers are held on stems $2 \mathrm{ft}$. long; mixed Ke/way's New Giant Gargantuan, plants tall bearing super-giant flowers of the most attractive colors; finest mixed.

French Giant Single Aster, vigorous and very floriferous; plant with large and fine long-stemmed single flowers which, when cut, . SEMI-DWARF ASTERS, 18 in.

Extra Early Hohenzoliern, large, feathery fls; early, good; mixed. Rose.flowered Aster, large, double as a rose; fine colors nixed. Paeony-fl'wd Glote, fine habit, densely double, fine to cut; mixed. Twarf Comet, large fuffy flowers, free.blooming, splengid; mixed. Record Ray, large, double, robust, fine colors, beautiful.

Gecord Ray, large, double, robust, fine coiors, beautiful. Gomet Express, very early large flowers; an excellent early aster. Queen of the Market, one of the earliest and most popular of Asters; large, well-formed, very double, showing many rich colors; fine to cut; showy in beds. Colors: White, Crimson, Dark Blue, Light
Blue, Deep Lilac, Rose, Scarlet, Bright Rose, Deep Scarlet, Carmine. Dwarf Asters, 8 to Is in.

Triunrh. Paeony-f'wd, incurved iike a paeony, very profuse, mixt. DWARF GERMAN, sin. excellent for pots and beds. mixed colors. BOLTZ S Bouquet, 9in. extra double, very profuse, mixed colors.

DWARF QUEEN, 14in. early, fine for pots and beds; mixed colors. Chrysanthemum Dwarf, $1 \mathrm{ft}$. extremely showy and freeblooming; fls full-double, finely imbricated and of extraordinary size; splendid for beds and pots. Colors; White, Bright Rose, Fiery Scarlet, Blush, Light Blue, Dark Blue, Crimson, Yellow, Lilac tin

A NEMONE, St. Bridgid, Kelway's superb very beautifullARTEMISIA annua, 5ft. lovely fragrant foliage; fine.

Langport Strain; large fls, semi-double, rich colors, mixed.

$\downarrow$ ARCTOTIS breviscana, 6in. a splendid plant for beds.

Grandis, African Lilac Daisy, 2it. white and lilac.

Both kinds in fine mixture, 5 cts.

ARGEMONE, Double White, 2ft. new, largc-fl'wd, beautiful.

Grandiflora, fine new hvbrids, superb mixed colors.

Platyceras, $3 \mathrm{ft}$. prickly: fls large. poppy-like handsomc. ARNEBIA cornuta, 2ft. prettv golden ts spotted brown.
ASCLEPIAS curassavica, 2 ft. lovely scarlet and gold cluot ers; beautiful and truly cverblooming; adapted for beds or pots. One of the good things. This plant is easily grown.

ASPERULA azurea setosa, $1 \mathrm{ft}$. charming annual, blooming frecly and continuously; fls azure blue, fragrant, showy on the plants and excellent for bouquet-making.

ASTER. Perennial, 3ft. n̂ne large-fl'wd, mixed. See page 23

ITRIPLEX cupreata, $3 \mathrm{ft}$. red with dark violet stalks. 


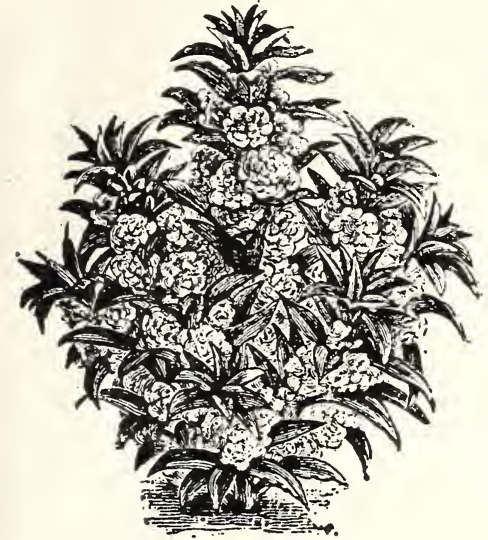

Balsams in full bloom

\section{-ALSAM, Double, Finest Improved}

\author{
Complete Special Mixtcre
}

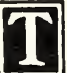

HE BALSAM is very desiralle as a garden annual. The seeas are sure to grow and, the plants bloom freely thoughout the summer and winter. They like a rich deep soil aud prtier partial shade though they will do well in a sunny exposure. Althouph splendid as garden flowers, if started in summer ald grow $n$ in pots they are grald for winter blooming in the plant-kindow or conservatory. The thowers are sur. passingly buautiful, being large, of waxy texture, skow fil e ru ge of charniing co.ors and variegations and are abundantly and continously produced until cut down by frost. If you grow but a half dozen annuals one of them should be the Improved Double Balsams. We offer the best quality of seeds of the best varieties and are confident they will give unbounded pleas ure and satisfaction. Our mixtures are specially prepared and contain all the colors in fine proportion. Try our fine Balsams.

\section{- Park's Prize Camellia-flowercd}

Special Mixture of Camellia-flowertd Balsan.s.

The finest of all Balsams, full double not unlike the unrivalled Camellia in form and texture and substance and appear in a great diversity of exquisite colors. Our seeds of these cannot be excelled. You can depend upon them for best results. We offer the following colors: Crimson, Alba Perfecta white, Prince Bismarck brilliant salmon rose,Pure Scarlet, Goliath chimois-rose, Lilac, White shaded pink, Ruse s.ottel, Scarlet spotted, Violet spotted, Rosy-lilac, separate or in splendid mixture $5 \mathrm{cts}$.

ouble Rose-flowered, Atrosanguinea, 2 ft. deep blood red; also splendid mixture of all colors.

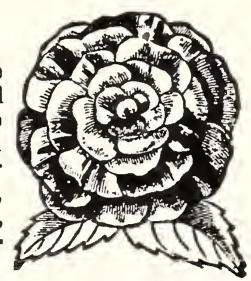
large flowered, extra double, growing over two feet high. and free and long blooming. Give them atrial.

The King, 30in. brilliant scarlet, robust in growth.

The Queen, satin rose, charming in color; a lovely shade. The Emperor, blue marbled with white; very effective.

The Princess, pure white; very double; a splendid Balsam. The Prince, yellow; very showy and beautiful.

Complete Mixture of all the above Royal Balsams, 5 cts.

We highly recommend our Balsams; thcy will delight you.

BEET, Chilian, 18in. ornamental, ribs scarlet, rose,gold mixt. Scarlet is especially fine for retired beds.

BIDENS dahlioides, 1ft. Wahlia like, large, showy mixed.

BORECOLE, striped, curled, coleus like, mixed; winter beds. Palm-tree, 6ft. Palm like, also fine for winter beds.

BOLTONIA glastifolia, $4 \mathrm{ft}$. pinkish daisies, blooms Sept. Latisquama, $2 \mathrm{ft}$, plants branch; bear violet daisies frcely. BRACHYCOME, Swan River Daisy, Gin. charming freeblooming annuals, flowers small, aster like, very pretty, fine for edgings and beds; Blue, White, Rose; sep. or mixed.

Browallia elata is a hardy annual of easy culture. The plants branch, become bushy and are covered with the bright flowers that are always admired. Grown in pots they are fine for winter-blooming. They thrive and bloom in sun or shade and are very desirable plants.

Elata grandiflora, 18in. Blue, also White, sep, or mixed.

Roezli. 18in. large flowers, azure blue, very handsome.

Speciosa major, flrs. like a small Petunia; violet blue, also white; a fine pot plant for the conservatory.

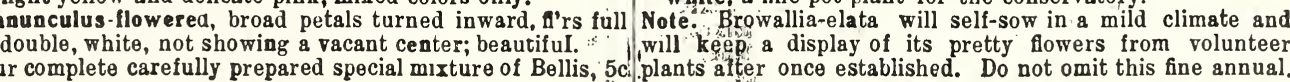

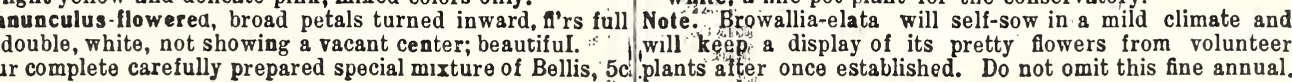

\section{CALLIOPSIS in Splendid Variety} Complete Special Mixture of all splend d variet cs, i cts.

0 LD, beautiful and pcpular hardy annuals that well deserve a place in every garden These flowers are beautiful. The plants are slender, branch freely and each branch is tipped with a graceful, rich-colored flower, so that a mass of plants makes a very attractive and pleasing display The flowers are also fine for cutting for bouquets and designs. Sow the seeds either in fall or spring. The dwarf sorts are fine for beds and bordens Nana bicolor, 1ft. Crimson King, Radiata. Star fin. mixed sorts. splendid rich crimson bedder. Nana compacıa, $1 \mathrm{ft}$, dark crimson Garnet, $1 \mathrm{ft}$. $\mathrm{n} \in \mathrm{w}$ bedding scarlet. Coronata, $2 \mathrm{ft}$ vivid yellow, fine, Aurea, 6in gold yellow and brown Drummondii, rich golden yellow, Beauty. 1ft yollow and brown. \begin{tabular}{l|l} 
Tinctoria, 3ft. gold and brown. & Cardaminifolia, gold and brown. \\
Superba, 1 ft, new bizarre shades, & Tall sorts mixed Dwarf mired.
\end{tabular} Hybrida fl. pl, $3 \mathrm{ft}, \mathrm{new}$, mixed, Complete mirture of all sorts, 5 ,

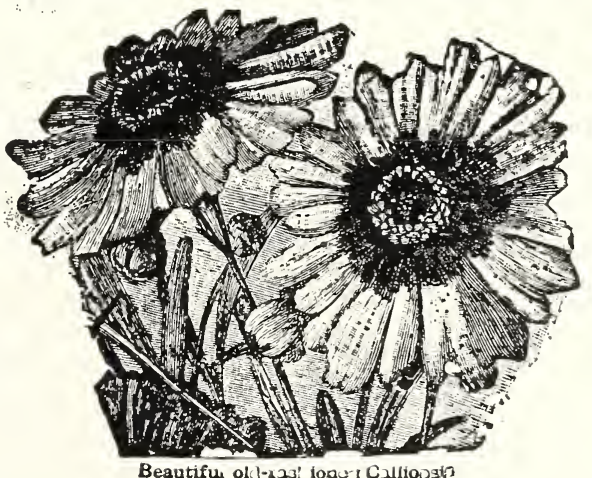

Beautifus of [1-223! ionos Callioust? 


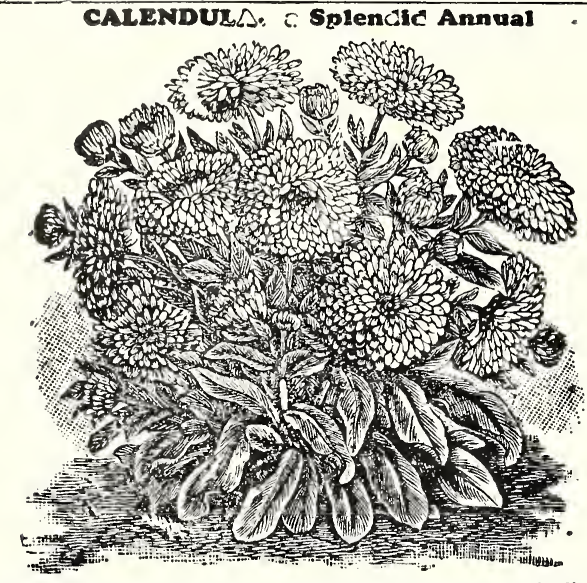

Not 3. For either garden or house the Calendula Officinalis in its improved varietias is admirable. The piants are easily started. grow - foot aigh, a dd bear a we llt n of large double flowers in rich golden colors, exce zdingly attrative in beds, showy in pots, and a treasure to the florist in making up cheerful designs. The seedlings quickly come into bloom, last Well, and in late autumn are rivals of the that has destroyed toir garden companions. We offer the finest colit *tion possible, and our geeds are of very superior quality.

Urange King Improved, very large full double orange flowers Ball's Orange, huzo, parfectly double deep orange flowers,

Le Proust, amoer yalluw, dark border and eye; double.

Favorite, double light yeliow with white stripes,

$M$ efeor, double sulphur with gold stripes,

Priace of Orange, fi le duuble, yellow with orange,

Sulphai Crown, large double lemon-colored; fine,

Pi jvialis, Single Cape Marigold, white,

Fongei fl. pl. Double Cape Marigold, white,

Conplete Special Mixture of the above Calendulas, 5 cts,

CACALIA, Flora's Paint Brush, 1ft, scarlet and yellow, mixed.

CALA.VDRINA grandiflora, 1ft, showy lilac-rose flowers,

Speciosa, 6in, spreading White, Rose, mixed; likes sun,

All varieties in fiae mixture, 5 cts,

CALCEOLARII scabiosafolia, 2ft, pretty little gold pouches,

CALLICHROA platygl issa, $1 \mathrm{ft}$, showy, rich golden yellow fis with white edge; a fine easily-grown, hardy annual,

CALLIRHOE involucrata, $1 \mathrm{ft}$, a handsome, trailing perennial of $\Theta a s y$ culture; fls cup-shaped, 2 in, across, rich crimson, Pedita, 2ft, cherry-red, alsc C, Lineariloba, both annuals,

CAMPANULA, Annual, These are beautiful garden flowers of easy cult ıre, They grow only about six inches high, but spread, and become a mass os exquisite bloom, Try them, Macrostgla, $1 \mathrm{ft}$. purple, rigid bristly stems, curious calyx, short gaping corolls and marvellous stigma make this a most distinct and interesting flower.

Speculu n grandiflora $1 \mathrm{ft}$, beautiful; Blue, White, mixed, Procunbens. 3in drooping Blue, White, Lilac mixed, Longistyla, 2ft peren'l. fis nodding, urn-shaped, blue, Lorei, $1 \mathrm{ft}$, violet-blue with light center; also White,

Attica, 4 in very neat and graceful, Blue, White mixed.

Comol ste mixture of annual Campanulas, $5 \mathrm{cts}$,

CANDYTUFT. Iberis, $1 \mathrm{ft}$. besutiful, free-blooming annuals for bets or borders. Of easy culture. Sow in spring or fall, Rock ${ }^{2}$, Empress, larga white Giant Hyacinth-fl'wd, white, Affinis, pure white, dwarf, Amara, common white, Lagasce, white, fragrant, Little Prince, dwarf, white, Pzctinata, white, sweet-sc'td. Ton Thumb, selected; white, Unbsllata alba, white, fine,

Lilacina,lilac, Purpurea, red,

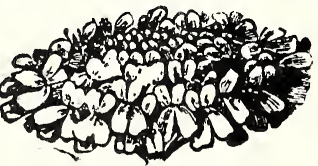

Candytuft in bloom Carminea, beautiful carmine. Umbellata varieties mixed, Dwarf hybrids, select, mixed, Com lete spacial mixture of Candytuft, $5 \mathrm{cts}$.

Candytuft. Hardy annuals of great beauty in beds, the flowers produced in umbels in great abundance, and of rich attractive colors. Seeds may be sown in Fall or early Spring where the plants are to bloon, and thinned to five inches apart. They appear best in masses. CANNA, 3ft. splendid named large fl'wd varieties, mixed,
CAENA TONB, BIOoming First Season Our splendid Chabaud and saryaret Carnations bloom from four to six months after sowing. See complete offering on Page 24. CANNAsIS gigantea, Hen p, $8 \mathrm{ft}$, excellcnt for back.ground. CARDJUS Beneaictu., 211, Blessed Thistle, yellow fis in heads, Kerneri, 3ft, rowust, large, strong-stalked, rosy heads, Marianus. 4ft, beautiful variegated folıge; striking,

CATCuFLY, Silene Armeria, 1ft, pretty hardy annual, that once suarted, will take care of itself, White, red, rose,mixed, CAPSICUM Chameleon, 18in, bears freely erect conical fruits which change trom yellow to scarlet: very beautiful,

Kaleidoscope, $18 \mathrm{in}$, white turiving to red: elegant for pots, Little uem. 18in, small. erect ganet Iruits, very showy. Prince of Waies, 13in orange Irvits, showy and handsome, Tom Thumb. small, rouna scarlet fruits; very profuse, All the above mixed, Fine potor garden plants,

CENTAURIDIUM drummordh, 2ft, branching, covered with pretty, large citron yellow fis not unlike a Centaurea,

CENTRANTI.US macrosiphon, 2ft, lovely tubular flowers in panicles, easily grown from seeds, and blooms for weeks; fine for beds, borders and rockery, Fine colors mixed,

CERINTHE major, Honeywort, 2it, brown and yellow for wees,

CHEIRANTHUS, Wallflower, 18in, Allionii, brilliant golden yellow, splendid for beds, showy and beautiful,

Kewensis, winter-blooming, see Window-garden pages,

Linifolius, 18in, lilac, very floriferous, handsome,

CHELIDONIUM, majus, 2ft, Celandine Poppy, pretty, showy yellow flowers in little umbels blooms al! summer.

CHENOPODIUM atriplices, 3ft clustered uright purple fis,

CHENOSTOMA fastigiata, 9in, tufts with fiery pink flowers,

CLAYT0NIA perfoliata, 6in, Winter Purslane, small white fis in loose racemes, sometimes used as a salad. annual,

COLLINSIA $1 \mathrm{ft}$, beautiful annuals blooming in 12 weeks after spring sowing. They bloom in Spring when fall-sown, and make a pretty border, The pretty, bright-colored fowers are borne in verticillate racemes Thin plants to $2 \mathrm{in}$, apart, Bicolor. two-colored, lilac and whice, beautiful,

Can didissima, splendid white, Carnea, flesh-colored,

Grandiflora, purple-blue, Carminea, rich violet-red,

Multicolor, fis marked white, violet and lilac, beautiful.

The above, all large-flowered sorts, in complete mix ture, $5 c$. CENTAUREA Cyanus, 3ft. Bachelor's Button, Hardy annuals highly valuable for cutting, the pretty fowers lasing well after they are cut, Emperor William, double, is the most desirable flower, of exquisite blue, for a button-hole, and can also be used in bouquets and designs to good advantage, The plants are readily grown from seeds, and bloom for a long time, Double, colors: White, Rose, Purple, Crimson, Plum Violet, Red, and Emp. Wm; sep, or mixed, 5 cts,

Cyanus, Dwarf, $1 \mathrm{ft}$. fine for beds, very free-blooming,

Victoria, blue, and Victoria in fine mixed colors,

Imperialis, Imperial Sweet Sultan, 3ft, Among the most showy and beautiful of Centaureas, and superior for crting. The flowers are large, bright, deliciously scented and lesting; showy in beds, fine in bouquets, and the plants are easily grown, We offer the finest improved sorts as follows: Alba, white, Iphigenia pink white center, Lilacina, lilac, Rosea, rose, Splendens, brilliant purple, Armida, lil c, Favorita, brilliant rose, Graziosa, intense purple, Whlte shaded rose; separate or in splendid mixture, 5 cts.

Depressa, 1ft. King of the Blue-bottles, blue vivid red center, Odorata, 2ft, very large flowers, excellent for cutting,

Chameleon, large sweet-scented, yellow and rose, fine, Margaritae, new, large white, sweet, highly prized to cut. Odorata varieties in fine mixture, $5 \mathrm{cts}$,

Moschata alba, White Sweet Sultan, fine to cut,

Coerulea Blue Sweet Sultan, also Rosea, rose

Moschata varieties in special mixture, 5 cts.

Suaveolens $2 \mathrm{ft}$. yellow Sweet Sultan, sweet, splendid,

Complete special mixture of all the above fine Centaureas, 5c. CELOSIA Cristata, the showy Coxcomb

Easily grown, showy and beautiful annuals for beds.

Tall Coxcomb, 18in, huge broad combs. Colors: Scarlet, Crimson,Yellow, Rose, Variegated, Paeony-red; sep. or mixed.

Dwarf, 1ft. plants with big showy combs, fine for beds; Crimson(Pres, Thiers), Scarlet(Glasgow Prize), Orange, Rose. Blood-red, Purple, Golden Yellow, Cardinal; sep, or mixed.

Magnifica, 2ft, branching, each branch tipped with a big showy plume; Colors: Crimson, Scarlet, and Golden Yellow. Splendid for beds, lasting, beautiful, attractive, sep, or mirt Childsi, Woolflower, big tufts of wool, charming colors mixt. 


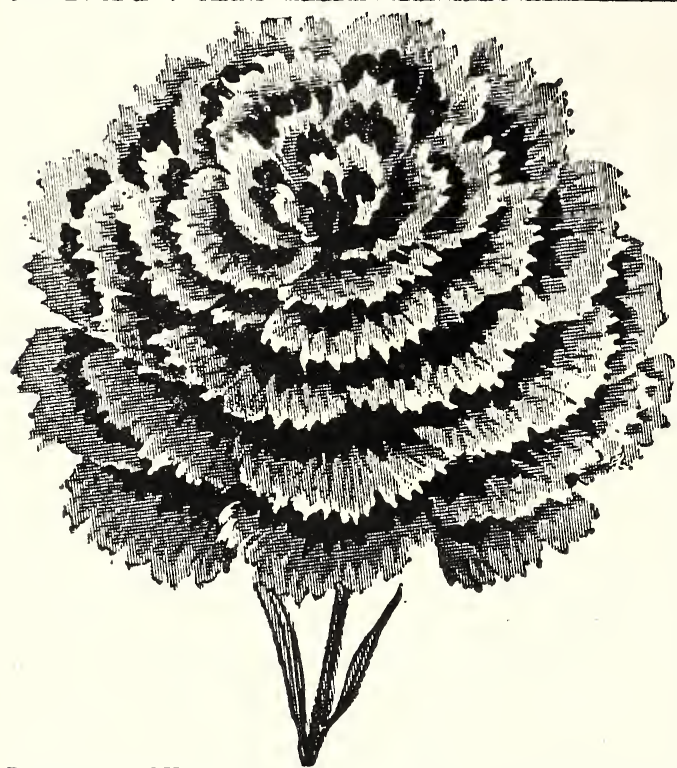

Fult-double LUCifER, The mort Intense Vivid-Scarlet Pin $K$ NOWN. RICH IN BOUQUETS AND SENSATIONALLY GORGEOUS IN BEDS.

\section{ESCHSCHOLTZIA}

0 :e of the most beautiful and showy annuals, a foot high, becoming a mass of lovely foliage thickly set with large, rich,

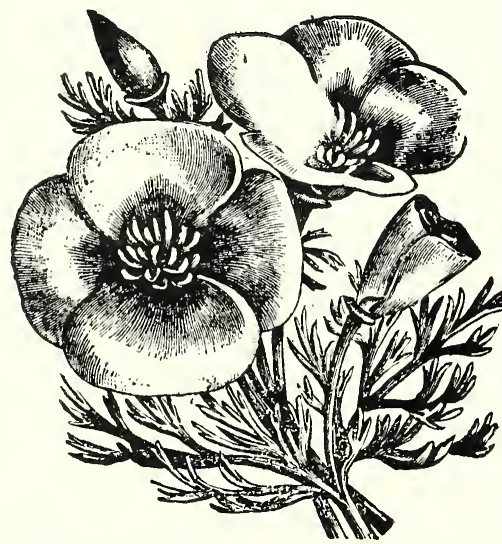
cupped blooms. ments have re- ground freezes. cently been ef- In Florida they fected, and our bloom more or list includes all less during winthe new shades ter. The plants and frilled and grow a foot nigh, fluted sorts, as and are splendid well as large- for showy beds, flowerd double while the large, and single. The attractive fowers splendid novel- are fine for cuttties will be ing. We offer a surprise to the annual as such as know well as the choice only the older pereunial kinds, varieties. $\downarrow$ the latter osWe list these pecially recomrare high-class mended for perEschscholtzias manent beds. in groups, and Our seeds axe supply thesorts unsurpassed / in

Eschscholtzia, Lovely Bedding or Border Annuals alone or mixed. quality.

Fine Large-flowered: Creamy Frilled and Fluted: Delicata, White, Carmine King, Chrome, white and rose; Ignea, fire-red; Lemon, Rajah, Crimson, Rose. Geisha,tile-red;Yellow fringed;

New Compact: Dainty Pink, Intensity, rich crimson-scarlet; Fire Red, Intense Scarlet, New Rosea, rose; Sulphurea, sulMauve, Mandarin, Crimson, phur; Tango, bronze and terraRose Queen, Wallflower Red. cotts; Ballet Girl, scarlet with

Fine Double: White, Orange. cream cup. Complete, careRose, Saffron, Yellow-edged. fully proportioned mixture, $5 \mathrm{c}$. Annuals, Single: Blood Red.| Semi-double, new, splendid; White, Yellow, Rosy-white, Rhinegau, yellow, red zone; Scarlet, White-edged, Quilled. Standholder, orange; Neudorf, $\star$ Lorenziana,Double: Red tıp- cherry red and sulphur;Sibylla, ped white, Red tipped yellow, vividcarminetipped white;OcuWhite, Dark Red, Sulphur. lata,light hues,eye: Sulphurea, $\star$ Perennials, Largest-flowerd: sulphur, red center; Kermesina Maxima, golden yellow; San- splendens, brilliant crimson.

Dimorphotheca, 1 ft, bright orange for beds Erodium gruinum, 1ft, Heron's Bill, blue Eutoca multiflora, 18 $\mathrm{n}$, blue, floriferous Hybrida many attractive colors mixed Erysimum compact, $1 \mathrm{ft}$,gold, for rich beds Viscida, $1 \mathrm{ft}$, rich dark blue, beautiful.

Eklonis, 2ft,new white, 3in, across, file Peroffskianum, 2ft, bright orange, fine

The above splendid sorts mixed.

Dracocephalum, Bee Balm, $2 \mathrm{ft}$., white.

Blue, in long spikes; showy; fine for bees

Echium creticum,2ft, scarlet, Boragewort Eupatorium Fraseri,2ft, white, for cutting

Plantagineum, purple, branching, fine Euphorbia variegata, 2ft, showy in beds

Els bolt zia cristata, 2ft, lilac, fragrant
Pulchellum 1ft, hardy, sulphur, profuse Fedia cornuana, 1ft, bright blue, profus

Eucharidium Brewerii,1 ft, large, carmine Fenzlia, 6in, profuse rosy flowers, lovely. Fragaria Indica, creeper, 6 in. red fruit.

Gamolepis tagetes, 6 in, yellow composite. Gardoquia betonicoides, $2 \mathrm{ft}$, purple spikes Gaura Lindheimerii, 3ft, white,fioriferous 


\section{Godetia}

Separately or in Complete Mixture, 5 eto

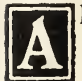

MONG the beautifulan-
nuals that are popular

in Europe the Godetia in many splendid varieties has a very prominent place. In beds they appear like immense sheets of exquisite color and variegation. The plants mostly grow a foot high, and are just smothered with the glorious masses of bloom. They start readily from seeds. Sow early in rows six inches apart, and thin out. We offer choice English-grown seeds of the finest single and double varieties. They will be a revelation to

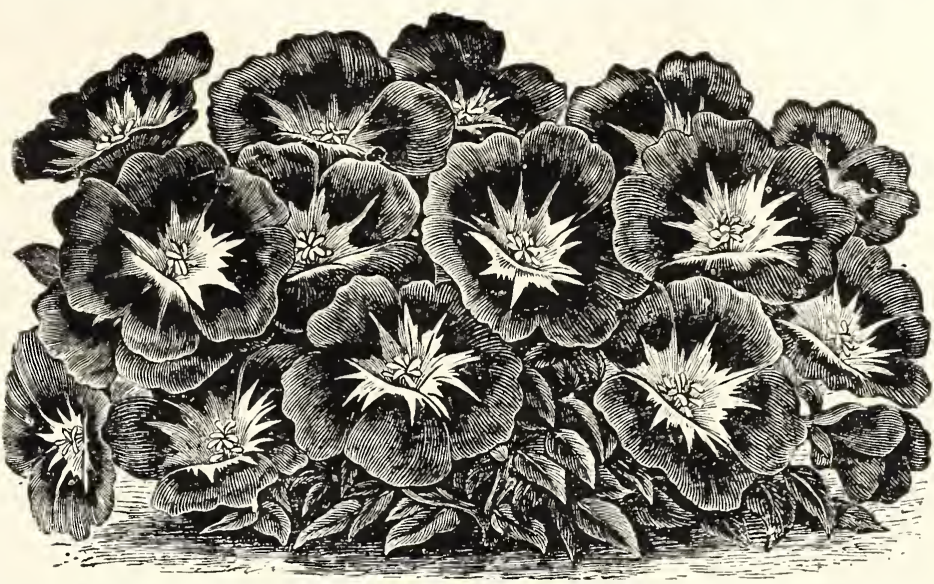

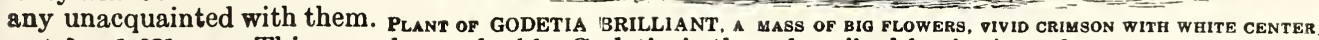

†Azaleiflora. .-This grand new double Godetia is thus described by its introducer: "Azaleiflora is one of the most striking novelties we ever had the privilege of introducing. It is an absolutely Hardy Annual, as striking as a rare greenhouse plant. The flowers are rose, with a carmine blotch on each petal, and cover the plant. The plants (15in.) are of splendid bushy habit, and look exactly like a greenhouse Azalea. Highly as we prized this flower at first we think still more highly of it now. It is a flower for every garden". 5 cents.

Fine Single Godetias

Duchess of Albany, dwf, satin-white; fine. $\star$ Brilliant, (see eng.) $1 \mathrm{ft}$. sm othered Cattleya, lilac blue with satin lustre, new Grandiflora carminea fl. pl. large, new. with large rich vlvid crimson flowers Mauve Queen, Heliotrope color,new, fine. Rosea f. pl. large rose, very attractive. with white center; very effective in beds, \Crimson Glow, dwf; intense dazzling Lilacina fi.pl. violet blue, new, srlendid. and fine for bouquets; the brightest and red,easily grown; makes a glorious bed. Whitneyii, fl.pl. brilliant scarlet flowers. best of single-flowered Godetias. 5 cts. Rosamond, dwf; brilliant rose, satin lustre Schaminii, fl.pl. $2 \mathrm{ft}$, bright rose, lovely. Aurora, new, dwarf; soft rose; charming. Lady Satin Rose, very brilliant, finest rose Rosy Morn, 2it, coral pink, superb dbl, new Gloriosa, dwarf; large, darkest blood-red.|Princess Henry, satin rose, broad red spots Single Mixed: Double Mix ed;All Mixed 5c.

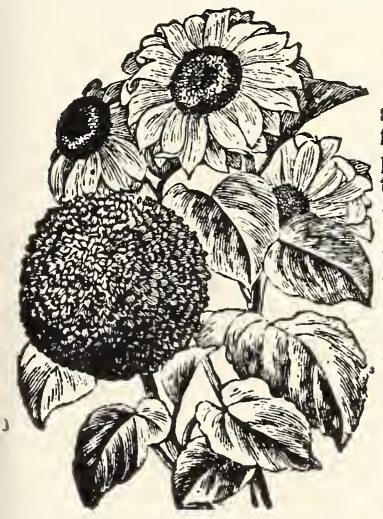

Becia bloom, 6ft; $\not$ Nana $\mathrm{fl}$.

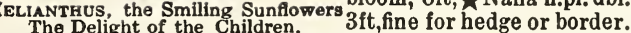
$\star$ Gaillardiiflorus fl. pl, new, showy; flowers large, red and yellow, not unlike a huge double Gaillardia; very attractive.

Small-flowered: Stella, gold, black eye; Purpureus, shades of red; Diadem, lemon,dark eye, cactus petals; Lilliput, globular plants, 8 inches high, gold, dark eye, free-blooming; $\star$ Erato, like Cactus Dahlia, cream, showy black center; Stellatus, double, colors white to sulphur and gold, new, mixed.
Large Sunflowers Mixed; Small Mixed; or All Mixed, 5c.

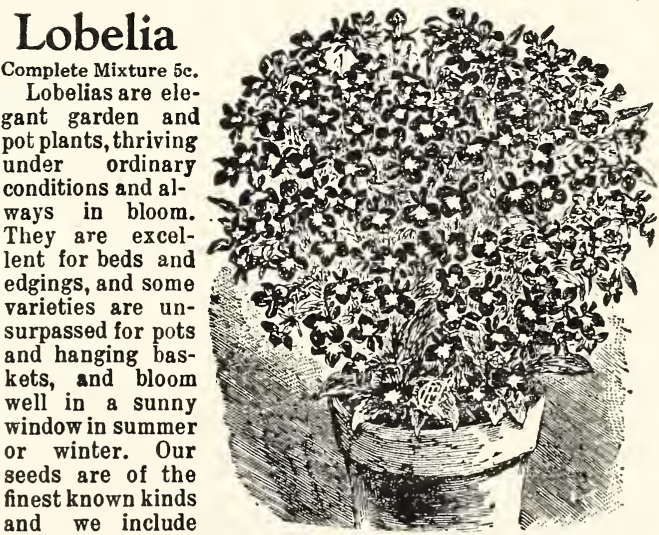

cultural directions. LOBELIA, Unsurpassed for Pots and Baskets. Barnard's, 8in, blue, white eye New Pendulous Lobelia: Best White Lady, 4in, large-flowers. for hanging baskets, and winCrystal Comp.4in, ultramarine dow boxes; new very beautiful. Emperor Wm.4in gentian blue Angelina, pure white, profuse. Snowball, 4in, snow-white. Amanda, red, large flowers. Speciosa, $1 \mathrm{ft}$, deep navy blue. Hamburgia, azure, white eye. Heavenly Blue,1ft, (Ramrosa) Sapphire, intense blue. eyed. Prima Donna,rich velvety red. These basket sorts mixed 5cts.

-Gazania longiscapa, 1ft,showy and very $\star$ Gypsophila Elegans, 2ft, splendid for Gerardia hybrida, 3ft, profuse, mxd colors

besutiful for beds or pots; lovely golden flowers with white spotted brown ring, of easy culture; a flower for everybody. Don't fail to include it in your order.

Glaucium tricolor, 2ft, orange Poppy, fine. Leiocarpum, $3 \mathrm{ft}$, fiery scarlet, new.

Burbank Hybrids, 3ft, large; perennial bouquets;profuse and long-blooming, easily grown. We offer

Maxima alba, large-flowered white.

Carminea, new, beautiful. rich red.

Rosea, lovely rose, very handsome.

All colors in complete mixture.

Muralis, 6in, pink, free-blooming, fine.
Gladiolus Praecox, early blooming, mixed Gossypium, cotton, 2ft, white, large.

Grahamia aromatica, yellow, fragrant. Hebenst reitia comosa,2ft, white,fragrant. Herniaria, 2in, used where grass fails.

Hibiscus calisureus, $1 \mathrm{ft}$, cream cups, eyed

Jonopsidium acaule, 4 in, lilac carpet. 


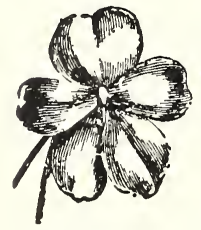

Holsti Flower
IMPATIENS, Holsti and Sultani T hese are everblooming plants, useful for partially shaded
beds, and unsurpassed for pots in the window. The flowers are graceful, of various rich colors, and always atractive. Other kinds are likewise desirable. HoIsti, 2 feet high, branching; continually covered with bloom; all colors from white to carmine. Mixture 5 cents.

Amabilis, $1 \mathrm{ft}$, carmine-rose, striped, dark eye; fine pot plant. Liegnitzia, 1ft., brilliant vermilion, free-flowering; charming. Sultani, Zanzibar Balsam; hybrids of many fine colors mixed. Queen Carola, chamois; a new and attractive color; splendid. Balfouri, 2ft, the new Orchid-flowered Balsam; rare and fine. Olivieri, $3 \mathrm{ft}$, robust, branching; large, showy, rosy lilac flower. Roylei, the Giant Balsam; 7ft; profuse, showy, scarlet flowers. White Queen, a Giant Balsam with pretty white flowers; $7 \mathrm{ft}$. Complete Mixture of all the above fine Impatiens, 5 cents,

\section{KAULFUSSIA Amelloides}

A dwarf hardy annual, 6in. nigh; dalsy-like flowers, white, violet, crimson, good for beds or edges; $m x d$.

Jochia Childsii,an improved sum. mer Cypress; turns to glowing red in autumn. 3ft; Burning Bush. Lallemantia canescens, blue, for bees Lasthenia californica, $1 \mathrm{ft}$, rich yellow
LARKSPUR, Annual

Very beautiful annuals, Easily

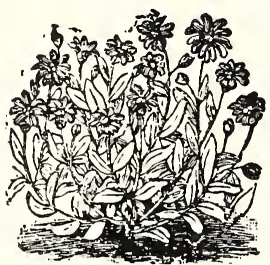

Kaulfussia Plant grown. Sow in spring or Fall where plants are to bloom

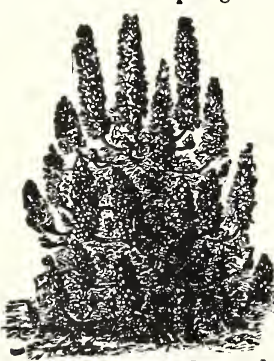
In beds they make a brilliant display, surpassing description. The tall sorts are fine for cutting: the Hyacinth-flowered are not unlike blooming Hyacinths, come in many splendid colors, and are glorious. Don't omit annual Larkspurs from your order.

Stock-flowered, 3 feet, Double: White, White striped blue, Bright Rose, Lilac,Azure,Violet,Tricolor, Dark Blue, Carmine, Rosy Scarlet. Separate or mixed, very choice.

Emperor, 2ft, Double, splendid. LARKSPUR, Stock-flowered colors mixed; extra choice,

Dwarf Hyacinth-flowered, 1ft, Double: White, Rose, Buff, Azure, Blue, Violet, Red, sep.or mix

Giant Hyacinth-flowered, 3 feet. Double: White, Rose, Red, Indigo, Violet, Reddish Gray, sep. or mxd. Dwarf Candelabrum, $1 \mathrm{ft}$, fine mxd.

Layia Elegans, $1 \mathrm{ft}$, an early freeflowering annual;flowers Aster-like, yellow with white margin; fine for beds. See Engraving.

Leptosyne Stillmanni,18in.early, free-blooming, the flowers daisylike,golden yellow;also L. Maritima 2 feet, large-flowered golden Marguerite. Both kinds are showy in beds and fine for cutting.

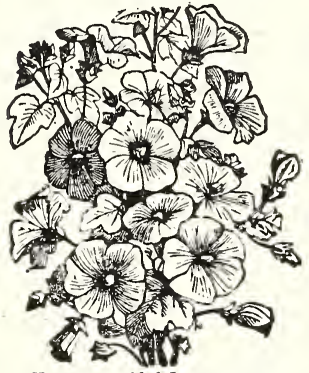

LAYIA Elegans, pretty annual Lavatera rosea splendens, annual, $3 \mathrm{ft}$. Hollyhock-like, fine. Alba, very fine white,improved. $\star$ Sunset, splendid for beds or borders; new. These Lavateras are hardy annuals of great beauty for showy beds, as also for cutting, the flowers lasting well in vases. They deserve a place in every garden.

L. Olbia, 5ft, hardy shrub with long sprays of rose-pink flowers; does well for borders, also for pots in the window.

Limnanthes Douglassi, 6in. The Beautiful Lavatera yellow and white, sweet,for beds

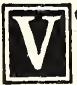
LINUM, Ornamental Flax ery showy in beds, $1 \mathrm{ft}$, flowers brilliant scarlet-crimson, easily grown, beautiful L.Usitatissimum,2ft.blue, fine; L.Lewes blue,handsome. Separate or Mixed. LINARIA, Annual,1ft.;very beautiful summer flowers of easy culture; very "showy in beds Aparinoides, spikes of golden flowers, showy;. Linum, Flax Bipartita alba, white; also deep Violet; Excelsior Hybrius, in splendid mixture; Reticulata aurea purpurea, golden yellow and dark purple, separate or mixed. These are all lovely. Bipartita plants in bloom look like giant Lobelias. The $\mathrm{Ex}$ celsior Hybrids show violet, pink, red, blue and golden hues and are charming. You should surely have these.

LINARIA, Perennial:- These embrace L. Cymballaria or Kenilworth Ivy, the drooping kind, unequalled for a basket bracket or pot, and for carpeting. We also have the Compact White, beautiful as an edging or for pots; and Globosa which forms dense globular plants 6 inches high, smothered with bloom. These new hardy kinds we heartily recommend. They. do well in sun or dense shade, bloom freely and continually, and are sure to please. Another fine hardy Linaria is Mace. lonica speciosa. It also blooms the first season, growing $3 \mathrm{ft}$. high, and producing long spikes of golden flowers. Fine in beds, and good for cutting. You will not regret it if all these lovely Linarias are added to your order. Dont forget them.

\section{LUPINUS}

We offer these splendid Lupines: Albo Coccineus, 2ft, red, white. Cruikshanksi, 4ft, dark blue. Hirsutus, $3 \mathrm{ft}$, blue, white,red,mix Romulus, $1 \mathrm{ft}$. large, yellow, fine Atro-coccineus, rich scarlet, 2 ft. Mutabilis versicolor, various, $3 \mathrm{ft}$. Nanus, $1 \mathrm{ft}$, for beds, blue, white Albo coccineus, Scarlet, showy Albo-coccineus Rose and white.

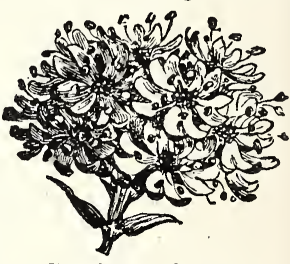

The Showy Lychnis Sub-carnosus, spikes of rich blue; excellent for cutting. Sulphureus superbus, $2 \mathrm{ft}$;; beautiful yellow in large spikes. Hartwegi, 2ft; Blue, White, Azure, Rose. Red, sep. or mixed. Harkness Polyphyllus Hybrids, 3ft, splendid; many colors; $w$ xd Kelway's New Hybrids,3ft, perennials, superb big spikes,mxd Nore- Atrococcineus is considered the finest of annual Lupins, being a rich, deep scarlet with white. It is beautiful. Nanus Albo-coccineus Scarlet, Rose, and Violet, all with white, are showy in beds and very fragrant. Hartwegi is splendid, the flowers coming continuously in long spikes, and deliciously scented; fine for cutting. All are of easy culture. You will like them. Hartwegi is the Celestial or Heavenly Lupin French Hybrids, 5 in. new, many colors mixed; beautiful.

Lychnis Arckwrightii, 2ft.; new Hybrid; many rich colors mxd Chalcedonica, $3 \mathrm{ft}$, showy scarlet flowers; fine in beds.

Haageana, 18in;lovely hybrids; large flowers; showy and fine Lychnis Viscaria splendens, $1 \mathrm{ft}$.,panicles of rosy-red flowers Leucanthemum vernale, the spring Marguerite, 2ft, white. Shasta Daisy, 3ft, large, showy flowers; mixed varieties.

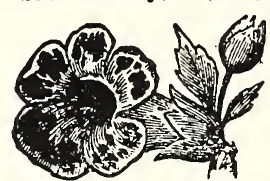
MIMULUS, Monkey Flower Very pretty, easily grown flowers. Cardinalis, 18in, scarlet, fine. Cupreus, Bismarck, 1ft, fiery red. Moschatus, 6in.,musk, for pots; yel. Quinquevulnerus max. large. Tigrinus, $1 \mathrm{ft}$, yellow, tigred. Mimulus, Queen's Prize Duplex Imperialis, double fine. Queen's Prize, giant spotted; Fire King large, red, splendid. These fine varieties separate or in Complete Mixture.

Malope grandiflora, $3 \mathrm{ft}$, showy garden annuals; flowers like small Hollyhocks, White, Rose, Red, separate or mixed.

Malva Crispa, $7 \mathrm{ft}$, fringed foilage. Mauritiana, 4ft, purple veined lilac. Moschata, $2 \mathrm{ft}$.,Rose, also White. Both mixed. Martynia Fragrans, 18in., red-violet, showy, fragrant.

Lutea, a pretty Brazilian annual; flowers yellow, clustered.

Tricolor, rose with dark spots; useful for groups and borders.

Proboscidea, white, yellow and violet; showy, easily grown; pods called Devil's Claws, used for pickling when green.

Mixture of all the varieties, 5cts. Mesembrianthemum, Ice Plant.

Pomeridianum, 1ft, yellow, fine

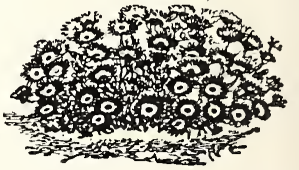

Tricolor, 6in,three-colored,fine Mesembrianthemum Tricolor 


\section{Marigold, Fine Varieties

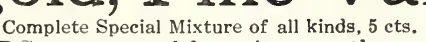
ARIGOLDS are general favorites, as they grow well in any soil or climate, are showy, free and continuous-blooming, fragrant, and beautiful. We offer the finest African and French varieties, and our seeds are of the best quality. Signata pumila is a grand edging, a foot high, and shows a mass of rich golden bloom. Lucida a native of Mexico, is exquisitely scented, rare, and very handsome.

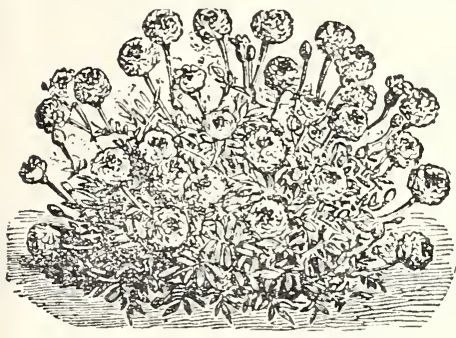

Blooming Plant of Double French Marigold

Double French, Tall: 3ft., Large Brown, Urange, Yellow and brown, Brown quilled, Orange quilled. separate or mixed.

Double French Dwarf, 1ft, Orange, Brown, Yellow, Sulphur, Yellow and brown. Striped, Redäish brown, Yellow and brown quilled, Orange and brown quilied, Brown Edged yellow, sep.or mxd. Single French Marigolds, Tall striped, very showy. Legion of Honor, 9in. Yellow and brown. Gold-margined, brown, gilt edge.

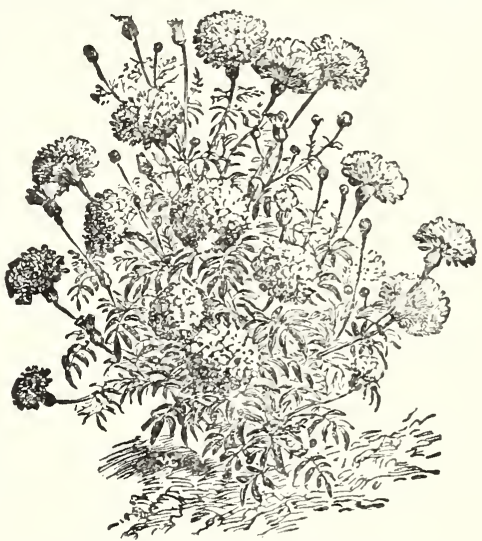

MARIGOLD, African Large Flowered Silver King, sulphur, spotted; The Flowers are as large, as Rict-colored and as

Double African Marigolds, $3 \mathrm{ft}$, bearing large, very double golden and sulphur flowers, some plain, some quilled. Good specimens rival Dahlias in size and show iness. Tall Lemon; Tall Orange; also Dwarf Lemon, Dwarf Orange. We also supply Quilled Lemon and Quilled Orange. Separate or mixed.

Tagetes Signata Pumila, Ift, each plant becoming a globe cf rich yellow bloom; fine for beds or borders; bloom till winter. Tagetes Lucida, 18in. deliciously fragrant; yellow clusters.

NEMESIA, Growing nine inches high, branching and bloom. ing profusely we have this splendid annual, It is easily grown. pure white, free-blooming, beautiful. Capensis fl.pl. white, ing profusely we ha
double. Eximia fl.pl. double, white, large-flowered, quilled; White Gem, lovely.
Golden Ball, 1ft, golden yellow, double, quilled, profuse, fine Blue Gem, azure.

Matricaria alba plenissima, (Feverfew) 2ft, extra double, pure white, free-blooming, beautiful. Capensis fl.pl. white, for beds. Silver Ball, lft, white, double, quilled, profuse; fine Triumph, large, dwf

Matthiola bicornis, $1 \mathrm{ft}$. sweet scented Erening Stock; lilac. Nana Compacta, mx Mimosa pudica, $2 \mathrm{ft}$, Sensitive Plant; rose, fine pot plant. Large-flowered, $\mathrm{mx}$ Spegazzini, Tree Sensitive Plant; fine for pots in the window. Mirabilis, Marvel of Peru, Fouro-clock, Tall, 2ft, Carmine, Crimson, Chamois, Red and White, Lilac, Yellow, White, Yellow and Red; separate or mixed.

Mirabilis, Tall, Variegated-leaved, Carmine, Crimson, Rosv sarmine, Tricolor, White, White with red, Yellow, Yellow with red,sep. or mxd.

Mirabilis, Tom Thumb, 1ft, Carmine, Dark crimson, Tricolor, White White with red, Yellow with red; separate or mixed.

Mirabilis Longiflora, 2ft, White, Violet, separate or mixed. Note. The Four-O'clocks are lovely, showy, easily-grown flowers, and are favorites with children, the flowers being attractive, and the plant readily started from the large seeds.

Molucella laevis, Shell Flower, 2ft, white, peculiar calyx.

MIGNONETTE, 1ft, flowers small, freely produced in long spikes, and deliciously scented. Fine for garden beds.

Grandiflora, very sweet, oz 25c | Giant Pyramidal, 18in, large. Improved, similar to above. Golden Queen, golder spikes ^Bismark,robust. red spikes, Goliath Red,mammoth spikes compact growth; extra fine Victoria Perfecta, red, extra Nachet rubra, glossy scarlet White Pearl, finest white. Gabriele, red, large, splendid Parson's White a fine old sort Golden Yellow, finest yellow Large-flowered, sorts mixed. MYOSOTIS, Forget-me-not, 1ft, lovely garden flowers, easily grown from seeds. Our seeds will give the best results. Alpestris White, Blue, Indigo, Rose, Victoria Azure, sep. or mix. Elise Fonrobert, large-flowered, blue, central flower double, Victoria rosea, early, large, best for pots and beds, charming. Indigo, new, rich ciusters, compact, very beautiful, the best.

Triumph, blue; blooms 10 weeks after sowing, globutar, fine Stricta, Royal Blue; pillar-like, large flowers; fine for beds. Ruth Fisher, largs, long-blooming, bright blue, superb for pots Dissitiflora Perfection, blue, large, plant compact; free bloom. Palustris semperflorens; blue,blooming from Spring till Fall, Sylvatica, Wood Forget-me-not, blue, free and long-bloomin
The varieties separate or in Complete Special Mixture. Lilacina, small.free Versicolor, smallflowered; blue,lilac and white, mixed, Complete mxdofall

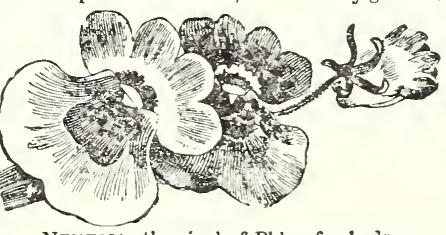
Nemesia, the rival of Phlox for beds. NEMOPHILA, Spreading little annuals, 6 in. high, bearing lovely

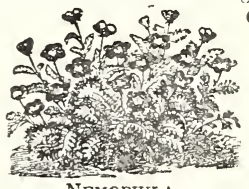

NEMOPHILA

NIEREMBERGIA, Cup flower; $1 \mathrm{ft}$. Frutescens, lilac, fine Gracilis, light blue, free-blooming, for edgings, beds or pots.

NIGELLA, $1 \mathrm{ft}$, beautiful, easily-grown hardy annuals, the flowers large, and charming in orm and colors;lace-iike foliage. Miss Jekyll, Double, finest blue; also Miss Jekyll White.

Hispanica, pale blue, pretty. Diversifolia,various leaved, blue

The four varieties of Nigella separate or mixed. 5 cents.

NICOTIANA, very handsome. Plants are readily started from seeds, thrive in a rich sunny bed, and bloom profusly throughout the season. Affinis, 2ft, star-like, white, deliciously scented; Affinis Hybrida, mixed colors; Sanderae hybrida, $2 \mathrm{ft}$, rich colors, splendid, mixed; $\star$ Crimson King. 2fi, new, very rich color, free-blooming, supero for beds; Grandiflora purpurea, 3ft, large, purple; Macrophylla gigantea, $7 \mathrm{ft}$, pale red Sylvestris, $5 \mathrm{ft}$, long-tubed white flowers. Separate or mixed. NOLANA, Chilian Bell-flowex; 6in, trailing, blue, white,mxd. NOTOBASIS syriaca, the elegant Syriar Thistle.

NYCTERINIA Selaginoides, 6in. pink; Capensis 1ft, white. TOBELISCARIA showy Obelisk flower, $1 \mathrm{ft}$, petals red,gold edge. OENOTHERA E.Primrose, 3ft.,Glow, new, red calyx. Lamarckiana.4ft, Drummondii 2ft, Acaulis 6in. Fraseri,1ft, Odorata, $1 \mathrm{ft}$. OCYMUM basilicum, Sweet Basil, in pots, for room ảecoration. OXALIS floribunda, for pots. Valdiviana, yel. Tropæoloides. OXYURA, free-blooming, gold edged, white, garden annual 5c. 


\section{Pansy \\ Complete Mixture, 5 cents.}

DE $\begin{gathered}\text { ThYONE who } \\ \text { cultivates flowers }\end{gathered}$ should have a bed of uur Giant Pansies. They are among the "indispensables," being of the easiest culture, very free-blooming, and exceedingly show$y$ and beautiful. Our seeds are of the best strain known, and will compare with any seeds offered by others at five times our price, 5 cts a packet.

Our plants are dense, robust and become a glorious mass of bloom, while the flowers are of mammoth size, exquisitely formed, and show a wonderful range of colors and variegations. We specially recommend our mixture, but can supply separately.

Pansy, Special Strains. Cassiers Blotched, rich spots. Bugnots Extra-large, mixed. Kelways Choicest Strain, mix. Masterpieca Exhibition, wix. Mette's Triumph of Giants. Benary's Non-plus-ultra, mix, Giant French, richly stained. Siriped Mammoth Parisian.

Giant Winter-blooming Pansales bloom throughout the winter when not too severe. The flowers are very large, of fine form, fragrant, and come in all the leading colors and variegations. Our seeds are of an improved strain, and very superior. We offer North Pole, pure white; Mars, corn-flower blue; Helios,pure golden yellow; Woden, almost black; Celestial Queen, white with blue eye; Winter Sun, golden yellow with eye; Jove, purple and white; Charm of March, blue. Separately or in Complete Mixture, 5 cents.

$\star$ New Spencer ransies. This new race of Pansies has very large flowers that are frilled and fringed ond crimped, making them appear as though almost double. The rich colors with the velvety texture and exqusite and quaint form give these Pansies a beauty that is exclusive and greatly prized. Fine for beds and window boxes, 5 cts.

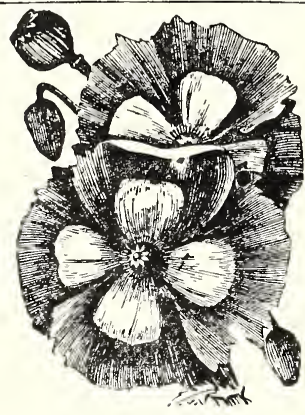

Scarlet Danebrog Poppy.

Other Fine Poppres.

Mikado, dble, white striped red Japanese Pompon,dbl fine mix Ranunculus-flwd, choice mix. Ariel, d'bl salmon, black spots Cardinal,dbl, rich colors mixed

\section{POPPIES, Bright and Showy as Paeonies.}

Complete Special Mixture of all classes and colors, carefully proportioned, only 5 cents.

Poppies are old fashioned flowers, but how showy and beauthul they are! Once in the garden they mostly take care of themselves. The large double ones are as handsome as Pæonies, and quite as showy and pleasing, while the single flowers show a wonderful diversity of shades and variegations, and are always admired. In garden beds and borders they, are truly gorgeous, and a few seeds scattered about the vegetable beds make bright and beautiful the vegetable garden without detriment to the growing plants. Poppiss should adorn every home, and it pays to use only the improved kinds we offer.

Splendid Paeony -flowered Poppies, Broad-petaled.The Paeony-flow'd Poppies grow eighteen inches high, and are not unlike Paeonies in form and general appearance. They are exceedingly attractive, of easy growth, and very satisfactory. Colors: White, Brilliant Rose, Salmon Pink, Cochineal Red, Cardinal Red, Striped, Deep Purple, á̆́d Pansy Violet, each, 5 cents. The same in fine mixture, 5 cents.

Double-flowered Fring-d, large, showy, flowers, the petals deeply fringed. Colors: White; White striped; Salmon-rose; Pink; Red on white; Scarlet striped; separate or mix.

\section{Fine Single Poppies. | Fine Shirley Poppies. Fine Nudicul Poppies.}

Lavigatum, deep rich scariet. Single, 2ft, Benary's finest mix Single New Hybrids, splendid. Deacock, scarlet, black zone. Lilliput, small, very profuse. Double, very beautiful, mixed. Umbrosım, glowing scarlet. Dwarf, $1 \mathrm{ft}$, salmon shades, fine. \These bloom first season; all Fielil Poppy, English scarlet. Dwarf, fine blue shades, superb the fine colors from white to

Danebrog, 3ft,scarlet,blotched Ryburg, new dbl, remarckable scarlet,also striped mix ed $5 \mathrm{cts}$

^New Sunbeam Ponpies,-Here is a new race of glorious Poppies. Plants are perennial, grow 18in. high, and bear on strong stems large showy fragrant flowers from May until October. Colors range from white to crimson, and frnm sulphur to glowing orange-scarlet. These new Poppies have a great future, for once introduced everybody will want them. Splendid for cutting. Award of Merit by Royal Horticultural Society. You will be delighted with these Poppies, $m \times d ~ 5 c$ $\star$ New Yellow Cardinal Poppies, very double, light canary yellow in color; $2 \mathrm{ft}$, very attractive in beds, $5 \mathrm{cts}$ $\star$ Shirley, Our Shirley Poppies are of the latest improved strain, and surpass all others;none better; only 5c 


\section{PETUNIA Kelway's Giant \\ Complete Special Mixcure, 5 cents.}

WT. $\begin{gathered}\text { E consider this the finest } \\ \text { strain of large-flowered } \\ \text { Petunias in cultivation. }\end{gathered}$ The Kelways of England were years in developing it to its present unequalled quality. The seeds were saved from hybridiz:ed flowers of select pot plants, and cannot be surpassed. They will produce strong, shapely plants covered throughout the season with flowers of mammoth size, exhibiting a grand array of the most pleasing and rare colors and markings. Fine for beds, pots and vases. You will not err in getting seeds of this splendid strain. Our seeds are direct from Kelway.

Kelways Perfect Model, very large, beautifully striped, blotched, spotted.'

Kelways Fringed, exquisitely crenulated, fringed, fine colors; splendid.

Kelways Royal Blue, true velvety blue; free-blooming; superb for beds.

Superbissima, Ruffled Giants,mixd. Large-throated,purple, rose and white and chrome yellow.

Complete Mixture of above sorts.

\section{Kelways Double.}

Perfect Model, carefully fecundated trom finest double blooms, mixed.

Finest Fringed, full-dbl, best mixed

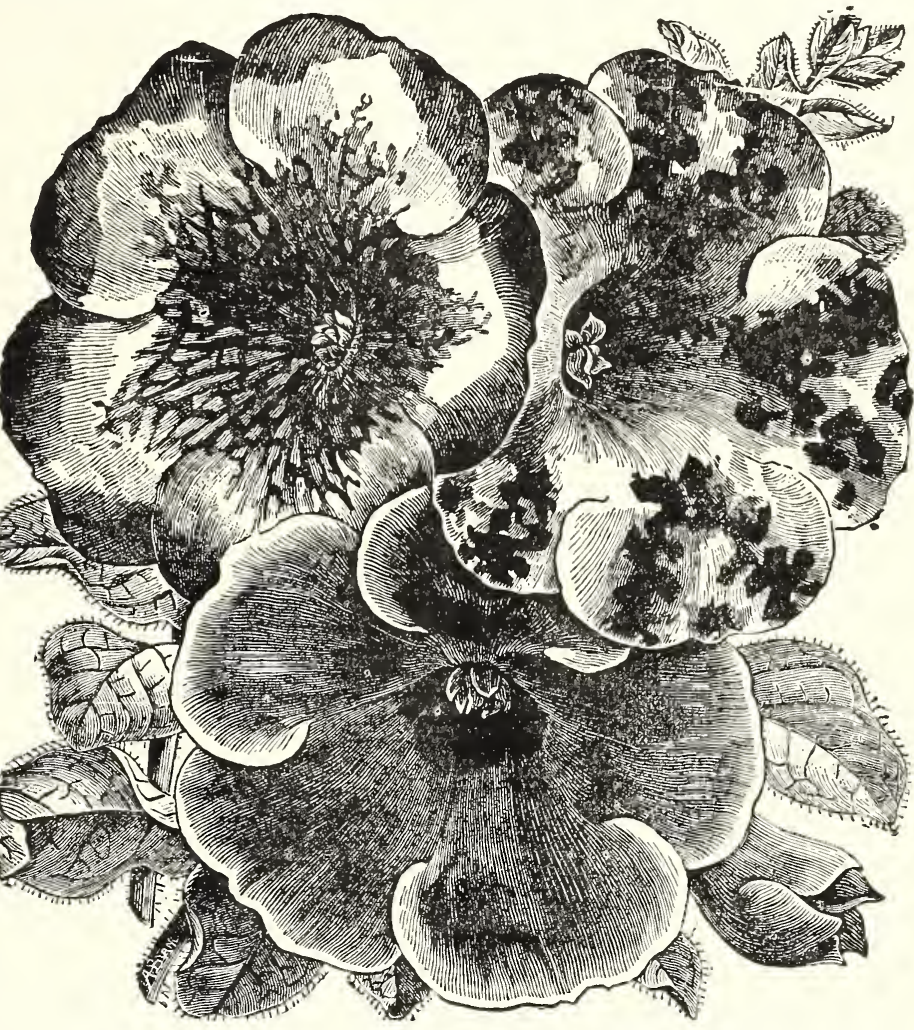

Brilliant Rose; DoubleWhite; both fine. Kelway's Petunias" of mammoth size, exhibiting a grand array of the most pleasing and rare colors Mixture of above sorts, 20 seeds 5c. Kelway's Petunias"of mammoth size, exhibiting a grand array of the most pleasing and ra

Fine Hybrid Petunias. Courtenay, red, yellow throat.|Dwarf Compact Petunıs|Hybrid Double Petunias Adonis, carmine, white throat. Marginata, white, red margin. Gloria, dazzling carmine-rose. Inimitable fl.pl, striped blotchAlba, pure white, free bloom. Rosy Morn, pink, white eye. Multiflora, striped, mixed. ed, free-bloom, double, beauBalcony, pendulous, mix. new Venosa, fine hues veined large Norma, blue, white star; free. tiful, mixed. 50 seeds, $5 \mathrm{c}$. Belle Etoile, purple, white star Complete mixture of hybrids $5 \mathrm{c}$ Rose of Heaven, fiery rose. Azaleiflora fl.pl.white, double. Gen. Dodds, darkest red, fine. Our Hybrid Petunias thrive in Snowball, white,very beautiful. Lilliput fl.pl. small free-bloom Inflata, new red. free bloom. hot sun and endure drouth, be- Stellaris, rose, white stripes. ing; fine for pots and beds. Maculata, fine spotted. Above Dwarfs for beds mix, 5c Complete Mixture,50 seeds, $5 \mathrm{c}$ Your special attention is invited to the high qualitv of our single and double Petunias. They are the best to be had. 5cts a packet. We challenge comparison with any seeds sold, regardless of price.

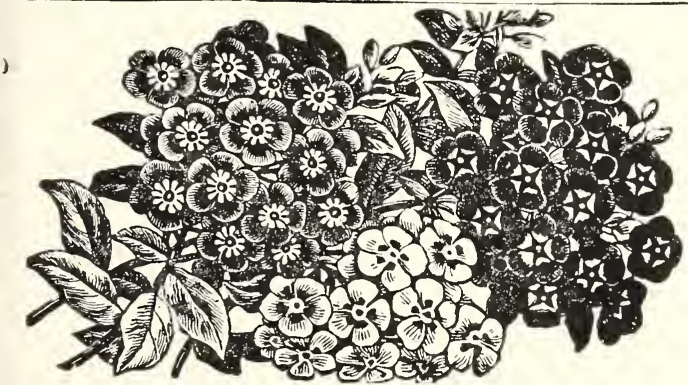

\section{PHLOX Drummondii}

Complete Special Mixture of all varieties, 5 cents

D. HLOX Drummondii is a native annual of Texas that has been greatly improved by cul-
tivation. The plants grow a foot high, and now bear much larger and finer flowers than originally, while they come in a wonderful variety of shades from white to blush purple and crimson, as well as in striking variegations. They bloom throughout the summer, and are exceedingly showy in beds and borders. We cannot too highly recommend them. The seeds offered are of the finest strains, and will please all who sow them. Grandiflora kinds are especially useful for continuous bloom in summer beds.

Phlox, prized for continuous summer bloom.

Improved Grandiflora Phlos: Pure white; Brilliant rose,edged light; Carnea, flesh; Coccinea, scarlet; Chamois rose; Crimson, white eye; Rose, white eye; Purple, white eye; Blue, white eye; Dark purple; Scarlet, white center; Purple, white center; Rose, striped white; Pure rose. Separate 5 cents, mixed 5 cents. These are all large-flowered sorts.

Other Choice Phlox: Hortensiflora, fine mixed; Cuspidata and Fimbriata mixed; Semi-double, mixed. Nana Compact mxd. -New Giant Perfection, We are much pleased to offer a new large-flowered Phlox Drummondii that surpasses all others. The plants grow 9in.high, branch freely, and are smothered with huge clusters of big showy flowers, very rich and varied colors, and making a marvelous display in a bed or in pots. We have Pure White; White marbled blue; Yellow; Blue, white eye; Azure with white center; Dazzling Red; Fiery Scarlet; Rose; Scarlet with big white center. Separate or mix ed, 5 cents. 
PENTSTEMON, For Beds

New Gloxinia-flowered, Mixed, 5 cts.

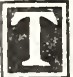
HIS elegant new bedding plant grows two feet high, each plant branching and bearing a mass of rich bloom, the flowers tubular, as shown in the engraving. They keep in bloom throughout the autumn. The plants are popular for bedding in Europe. Our seeds are of the large-flowered richcolored class and although perennial the plants bloom freely tixe first seasun. Being hardy they will endure the winter and bloom freely the following season. You will like this Giant Pentstemon for beds. Mixed 5cts.

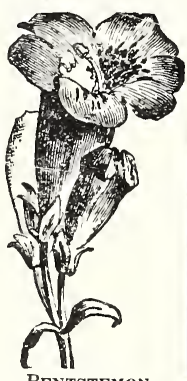

Pentstemon
PARSLEY, New Crested Gem, the most lovely plant known for table decoration and for garnishing; of dwarf compact habit, does well in pots; foliage fine-cut, dense, and prettier than the finest fern. Hardy, easily-grown, beautiful. 5cts. PERILLA Laciniatus, $2 \mathrm{ft}$. showy purple, fringed foliage; beds. PHACELIA Campanularia, 6 in. broad bell-flower, deep blue.

Congesta, 2 ft. blue, good in masses. Sow in bed and thin. Grandiflora, $5 \mathrm{ft}$. large-flowered, dark blue, rare, handsome. Parryi, 6 in. deep violet, flowers an inch across, beautifui. Tanacetifolia, $2 \mathrm{ft}$. bluish pink, pretty; fine bee plant.

Complete Special Mixture of all Phacelias, 5 cents.

Note:-- Phacelias are lovely annuals, and deserve a place in every collection. P. Campanularia has pretty blue bells in abundance;
Grandiflora has flowers over an inch across and is tall and showy.

PHYSALIS Franchetti, Japan Lantern; wreaths ef showy red "balloons;" dried for winter; of striking effect, 5 cents. Edulis, Ca'e Goosberry, $2 \mathrm{ft}$. fine edible fruits; excellent. Alkekengi, 2ft. n̂ne scarlet-red fruits, showy everlasting.

POLYGONUM Orientale, 6ft., lovely "tails" of bloom. Carmine red; also Variegated-leaved, separate or mixed, 5 cents

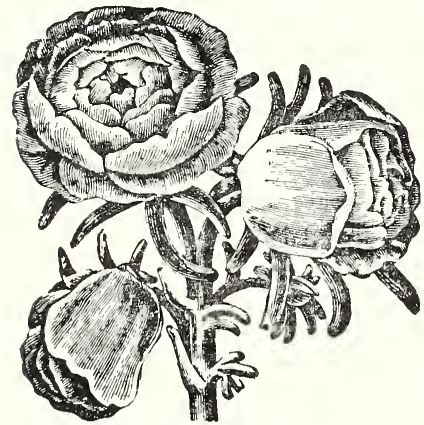

PORTULACA

Very showy and beautiful low succulent hardy añnuals that like sunshine. Plants should stand six inches apart. The flowers are borne abundantly, opening i) the morning and closing at noon. The rich colors and delicate texture of the flowers give them an attraction that few flowers have. The double-flowered sorts

The Beautiful Double Portulaca are more lasting than the single, and appear like little roses; the plants, however, do not all bear double flowers, even from the best seeds. Our seeds of Double Portulaca are of a choice strain, and most of them will produce double-flowering plants.

Double Portulaca, large-Ilowered, Alba, white. Aurea, Orange. Aurea striata, yellow striped orange. Caryophylloides rose with carmine stripes Rosea, rose. Salmonea, salmon. Splendens, purple. Separate or mixed, 5cts.

Sinsle Parana, very large-flowered, reddish purple, new. Sinzle, large-flowered, in splendid mixture, 5 cents.

PYRETHRUM parth. laciniatum Perfection, 6 in. compact.

Aureum, $1 \mathrm{ft}$. golden foliage, fine for beds and borders.

Golden Gem, $1 \mathrm{ft}$. golden foliage, double, white flowers.

Excelsior, 6 in. deop golden, splendid in bed or border.

Complets Sprcial Mixture of all above sorts, 5 cents.

Queen Anne's TYIMBLE

Here is a beautiful Gilia with little thimble-shaped flowers in clusters held above the fine feathery foliags, giving a most pleasing and striking effect. When cut, the long=stemmed exquisite heavenly blue cluster's are lovely in bouruets and last well in water. Sow in Spring or Fall. [t will prove a delightful surprise. 5 cts.

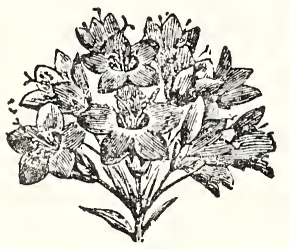

RICINUs, Castor Bean, Improved.

7 HESE are tall branching plants clothed with 1 large, ical leaves, often tinted rose or crimson. They are show$y$ and elegant in groups, and alvays attrac. tive. In mild climates they are perennial, and will grow twenty ft.high. The Zanzibar Ricinus grows more dense and has larger foliage than the older kinds. All are handsome, and give a semitropicalappearance to the grounds. Very easily grown.

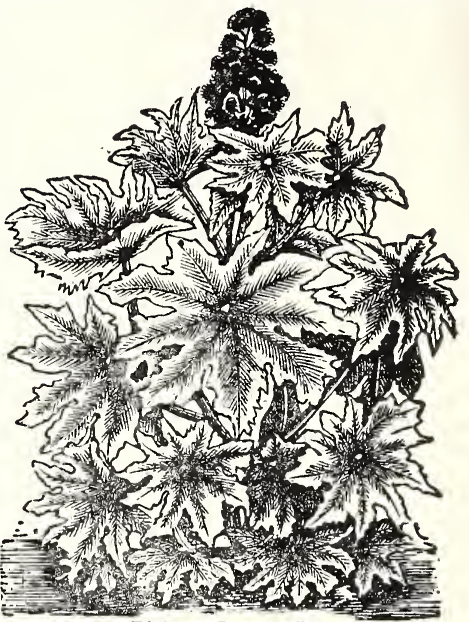

Ricinus, Castor-oil Bean

Borboninesis arboreus, $15 \mathrm{ft}$, green foliage, very ornamental. Panormitanis, $7 \mathrm{ft}$. giant brown leaves, blue stems, attractive. Sanguineus, $7 \mathrm{ft}$. red leaves and stems. One of the best. Laciniatus, $5 \mathrm{ft}$. dark foliage,finely laciniated; new, rare. Gibsoni, 5ft. bronze foliage and fruits; fine for a big hedge. Zanzibariensis, 7ft. robust, very large lobed leaves, mostly green; showy seeds. Cinerascens, Enormis, Maculatus, Niger, all fine varieties of the Zanzibar Ricinus we can supply separately or in complete mixture, 5 cents.

POD0LEPIS Chrysantha, $1 \mathrm{ft}$. a beautiful annual for a sunny bed; flowers golden yellow with pink; fine for pots. We also supply P. Affinis, a pretty annual. Both are easily grown. RANUNCULUS Asiaticus Superbissimus, $1 \mathrm{ft}$. exquisite large, double flowers in many rich colors; finest mixture. RICOTIA lunaria, 9 in, pretty annual; likes sandy soil. ROSA Nana Polyantha, the Baby Rose, $1 \mathrm{ft}$. Seedlings begin to bloom in four or five months. Lovely double and single flowers. Fine for pots. A beautiful novelty.

RUDBECKIA Superba, 2 ft, semi-double, rich golden yellow.

Newmannii, $2 \mathrm{ft}$, vivid yellow, long-blooming, gorgeous.

Purpurea Hybrida, $4 \mathrm{ft}$, rich red, varied, long-blooming.

\section{SALPIGLOSSIS}

\section{Complete Mixture 5cts.} inia-floweredSalpiglossis is an exceedingly handsome class of annuals. Plants grow 2ft, high, bearing abundantly and continuously large, showy richly-colored flowers, exquisite in texture, many strikingly throated or penciled. In a bed they are surpassingly beautiful, and enthusiastically admired; easily started and easily transplanted.

These choice varieties, separate or mixed, 5cts.

Salpiglossis New Gloxinia-flowered Brilliant Crimson, very rich. Lilac, veined golden yellow. Brown and Golden Yellow, fine Purnlish Rrown. pencilled. Chamois, tan, veined scarlet. Purplish Violet. fine color. Deep Scarlet, yellow throat. Rose, with fine purple veins. Faust, fine velvety black. Violet, veined golden yellow. The above superb large-flowered Salniglossis.sep. or $m x d 5 c$ The New Dwarf Salpiglossis, $1 \mathrm{ft}$.splendir. in fine mixture.5c.

SANVITAIIA Procumbens. fl. pl. a rreeping annual. pro ducing an abundance of double. hright golden vellow ficwers throughout the summer. Showy and beantiful. 


\section{SALVIA, Best Kinds \\ Complete Special Mixture 5 cents.}

FE HE Salvias are showy and veautiful either in beds 1 or pots. The plants grow from one to three feet and stashins. Ther starc readily from seeds and soon cone into bloom. Salvia spleadens is unsurpassed for showy beds.

Argentea, tf $t$, silvery foliage. |Patens, $3 \mathrm{ft}$. navy blue, splendid. Carduacea, 2ft. blue, very showy. Ringens, 2ft, large purple bloom. Coccinэ3, 3ft. fiery scarlat, fine. Roэmeriana. 18in. rich scarlet. Faria 1; 3, $3 \mathrm{ft}$. brizht-ligat blu 3. Sclarda, 5ft. white woolly foliage. Globjs3 4ft, white, gray foliago. Turkestanica, 5ft. bright pink. Horminum,2ft, red, whit, blue, mxd. These Species, sep. or mixed 5̄c.

SALVIA SPLENDE,
Bonfire, the Showy Bedding Salvia
16in. glowing scarlet,ilie. Glory of Stuttgart, 18in. scarlet. Fireball, 1ft, scarlet, very free. Semperflorens, $1 \mathrm{ft}$. intense red. Gigantea, 3ft,very attractive as sin- Zurich, 1ft., bright red, profuse. glэ spзci $n э n s$, an 1 for a tall borler. I Complete Mixture of splendens $5 c$. Note... I know of no more showy nor satisfactory bedding plant than Salvia. Seэdling 3 of Firaball, the new, best of Salvias, grow a foot high, begin to bloom early, and bacome a mass of big flaming spikes of bloom, lasting for months. Glory of Stattgart grows 13 inche3 hisl, and should be used for the center of throughout tho season. One pack th of Stuttgart and two of Fireball will produce plants enouga for an attractive bas. Sow in a box of good soil and when large en-
ough, 3 t tas plants eight inches apart in the bed. The three packets, only 15cts.

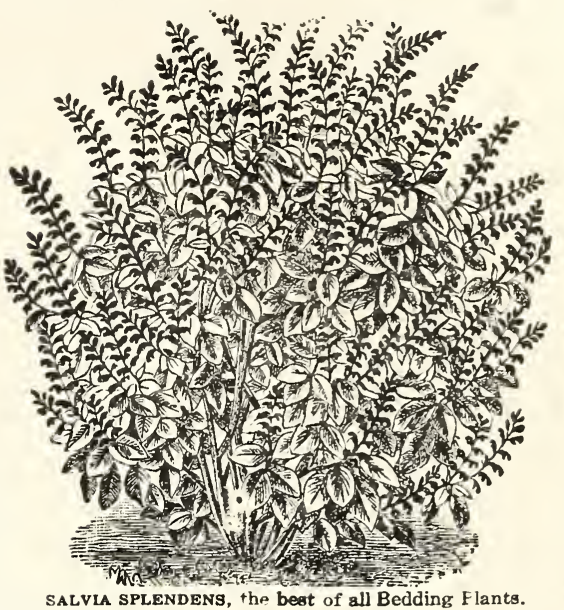

SAPJNARIA Multiflora, trailiag anl free-blooming showy annuals. Sow in Fall or Spring. White, Red, Mixed.

Scarlet Queen, $1 \mathrm{ft}$. very brilliant and beautiful.

Ocymoiles Splendens, a glorious trailing perennial, Showing a carpet of lovely pink clusters in spring; fine. Officinalis $\mathrm{fl}, \mathrm{pl}$. 2ft, large heads of soft pink flowers; a tonacious and handsome perennial. Fine for embankments. $\star$ Vaccaria Alba, $2 \mathrm{ft}$. exquisite white flowers; charming. Rosea, $2 \mathrm{ft}$. lovely pink in fine large panides.

Not3. Stponaria Vaccaria is very desirable for the cut-flower mar at, or for dэзigas. The flowers are small, but produced in gracefri suster 3 , a d ars not unlike Gypsophila in general appearance. excep and more easily grown. No flower-grower should be without thissplenand more easily grown. No flower-grower should be without thisspl
did annual. It ghould be a "must have" in every flower garden.

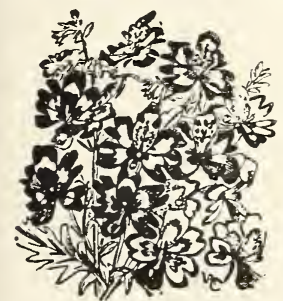

\section{SCHIZANTIUUS}

Here is a splendid annual, the plants growing a foot high, branch ing freely, and almost smothered with rich delicate orchid-like bloom, the markings being white, rose, gold, crimson and violet. The plants do equally well in beds or pots, and are always in bloom. The new large-flowered hybrids are especially recommnded. They are charming tLarge-flowered, White, Brilliant The Charming Schizanthus Crimson and Violet. Sep. or Mixed. Dwarf Hybrids, in finest mixture. Pinnatus roseus, fine rose. Rotusis Rosamond, fine rose. Trimaculatus, Albus, Lilacinus. Wisetongnsis Excelsior, best for pots; $1 \mathrm{ft}$, choice, improved splondid shades and markings. Bridal Veil, pure white Dr. B Itger's Hybrids, neir; fine. Sep. 5c. Complete Mixture 5c.

TRDPAEOLUM, Dwarf Nasturtium, 1ft, bright, free and continuous blooming annuals for beds or edgings. Colors: Apricot, Orange-scarlet, Vivid scarlet, Yellow flaked red, Bronzs, Carmine, Straw spotted red, Yellow, Pearl White, Gold King, Orang; spotted, Gold with yellow foliage, Yellow marbled scarlet, Black-rad, Salmon, Raspberry Red, Orange spotted red. Crimson, mar-
bled fon 3 ; Scarlet, marbled foliage.Separate or in Complete Mixture,

VINCA Rosea, 1ft, splendid everblooming plants for bods or pots; like hot sun. Flowers Phlox-like, beautiful. Colors: Rose, White, White eyed, Carmine, sep. or mixed. Viscaria, New Dwarf, 8in. free-blooming, beautiful annuals for beds or pots. Colors: Pure White, True Bue, Blood Red, separate or mixed, 5 cents.

Valeriana,3ft, Alba,Rosea, R:bra,fine to cut, sep.or mxd Vittadenia triloba, 8in. many rosy white daisies;fine edge

\section{SCABIOSA}

Very beau iful hardy annuals, showy in beds andfine for cutting. Easily grown. Sow early in beds and thin, or sow in a box and transplant. Set 6in. apart. We freely praise this lovely flower Tall Large-flowered; White, Rose, Scarlet, Brick-red Azure Fairy, Red and white, Purple and white, sep.or mixed. $\star$ New Dwarf Improved

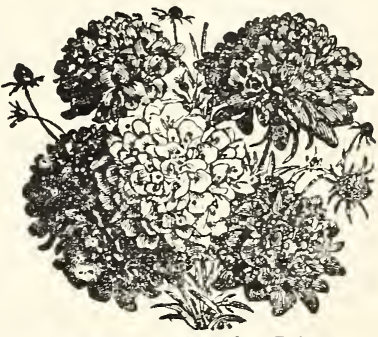

Scabiosa or Mourning Bride Double Large-flowered, 18in. Azure. Blood Red, Rich Crimon, Pure white, Purple-violet, Bright Rose, sep. or mixed.

S. Minor Aurea, 3ft, double golden yellow and $\mathrm{S}$. Candidissima, $3 \mathrm{ft}$, double white, good for cutting, each 5 certs. Note.-- We especially recommend the Dwarf Large-flowered Scabiosa. The plants stool out and cover the bed, stand erect, and bear a
wealth of lovely double flowers on strong stems. We feel assured yc will like this charming race much better than the tall varieties.

SILENE Pendula, Double, 4 to $8 \mathrm{in}$. exceedingly pretty, attractive hardy annuals of spreading habit. Flowers very abundant covering the plant. Fine for edgings and beds. Bijou, double, salmon, fine. Bonnettii, dbl, rosy magenta. Ruberrima plena. dbl, purple. Triumph,dbl, and Syringa Blue Aba fl. pl. and Rosea fl.pl.each Special mixture of all. Silene Maritima, 2ft. white, rare. S. Orientalis compacta, ruse.
STOCK, Ten Weeks and Virginia.

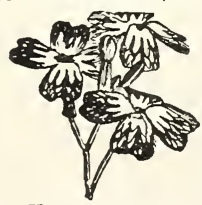

Virginia Stock The Ten Weeks Stock is the best of annuals. Plants are easily grown. and bear continually long spikes of flowers, as double as a Rose, deliciously scented, and of the loveliest colors. Our seeds are of best strains, and saved only from pot-grown plants. Dwart German, $1 \mathrm{ft}$. early-flowering, finest double. Colors: White, New, Beauty $2 \mathrm{ft}$, the fine, Light Blue, Rose. Separate or Mixed New Beauty, $2 \mathrm{ft}$ the finest of Stocks, profuse, double, and in
many choice colors: White, Rosy-lilac, Canary, Blood Red, Violet, Aumany choice colors: White, Rosy-lilac, Canary, Blood R
rora, Peach, Pink, Purple. Separate or Mixed, 5 cents.

Mammoth Column, $3 \mathrm{ft}$. one tall spike, double, showy and $\mathrm{k}_{\text {.u. }} \mathrm{u}-\mathrm{u}$ Mammoth Column, $3 \mathrm{ft}$. one tall spike, double, showy and $\mathrm{l}_{\text {-u }} \mathrm{u}-\mathrm{u}$
iful. Colors: White, Shining Blood-red. Separate or many colors mixed other Fine Stocks: Victoria Bouquet, $1 \mathrm{ft}$.; Large-flowered Dwarf 15 in.; Bismarck, $2 \mathrm{ft}$.; Giant Perpetual $2 \mathrm{ft}$.; Dresden Perpetual, $2 \mathrm{ft}$. White, Canary. These all bear fine double flowers; supplic in Fin
Mixture. Also, we supply a Complete Special Mixture of all sorts. STOCK, Virginia, $1 \mathrm{ft}$. showy, handsome annuals; fine for bed

Santolina, 1ft, Lav. Cotton, yellow./Solanum atropurpureum, 4ft, showy.|Spergularia azoroides, blue, small. Schizopetalon, 1ft, good-luck, scented . Giganteum, 10ft, blue, showy foliage. Sphenogyne speciosa, $1 \mathrm{ft}$, yellow daiSedum coeruleum, 3in. blue Stonecrop Senecio elegans, 18in. double, forbeds; White, Blue, Violet, Rose, Mixed. Isaciniatum, oft, very ornamental. sy-like flow srs, dark zone, beautiful. Albidum Portmannii, foliage plant. Stevia Eupatoria,18in. white corymbs Ciliatum, 1ft, scarlet fruits, thorny. Serrata, $2 \mathrm{ft}$. pure white, fine to cut. 


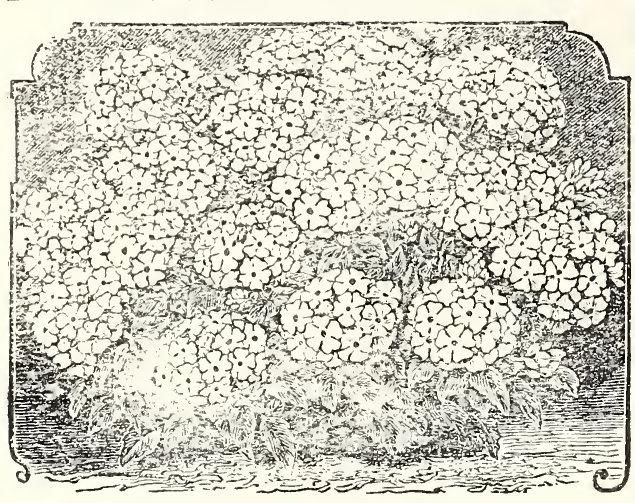

Verbenas, first-class flowers for pots or beds.
VERBENA, New Mammoth

HE Improved Verbenas are elegart summer-blocm致 ing pla:sts, the rich and fragrant flowers ccmirg in big clusters and making a fine display throrghout the season. Seedlings are easily grown, and thrive in any rich, sumny bed. They are among the most showy, pleasing and satisfactory of garden flowers. For pots use the Dwarfs. Snow Queen, pure w lite, fine. Striata, charmingly strifcd. Auricula, rich colors, eyed. Fairy Queen, lovely scft fink Royalty, vivid blue shades. Purple Cloak, red, white єye Firefly, dazzling scarlet, fine. Defiance, fiery scarlet.

Miss Vilmot, salmon-rose. Rose and carmine shades.

Pink, large-flowered, fine. Celestial, light blue shades. The above splendid Mammoth Vertenas, sep. or mxd. $5 c$. Uher Verbenas, Aubletia grandiflora, 1ft, lilac; Drummondii, various shades;Erinoides (Moss Verbena) Violet, also White, both profuse and continuous bloomers;Vencsa. $1 \mathrm{ft}$, for beds, lilac. Sep.or Mxd 5c. Dwarf compact mxdéc.

Note. Verbenas are firt-cluss flowers for inter The lars fuwers come in big clusters, are deliciously fragrant, good for cutting, and very attractive. By all means add V $\in$ rbenas to your list. Uur setds are oi the finest hiammoth strains, and will give the best results. The Mammoths are the most desirable of Verbenas.

Visla Cornita 6ia. protty Srotch Violets.

Thззз have the marits of Pansies, but are Violets in form. They bloom profusely and continually, and are quite fragrant. $T h\lrcorner y$ are beautiful flowers, of easiest culture that no garden should be without. We offer these finest varieties: White Perfec* tion, Blue Perfection, Lutea chrome yellow, Hybrid Viola Admiration deep blue, Rose Queen, Spring Messenger purple, trPapilio blue with white. Sep. or mixed, 5cts

Viola Tufted Pansies. These are lovely hybrids, and very desirable. We supply the best: Admirabilis blotched, Ardwell Gem chrome yellow, David Simpson marbled crimson, Firmament sky blue, Nora Marrow rosy-lavender, Primrose Dame sulphur, Purple King violet, Snowden white, all long free bloomers; sep. or mixed.

Viola, Bosniaca deep purple, and V.Munbyana early blue, both splendid species, separate or mixed.

Note. Viola Papilio. This is the Butterfiy Violet, so-called because fe the “butterfly fluttering of its petals." It is distinct and beautiful, and until cold Winter hides the plants under a coverlet of snow. Use for an edging or a bed; it does well in sun or shade, and always
elicits high praise from those who see it in bloom. 1t is a good thing.

Wa115 * wer Kewensis, a very fine kind, blooms 5 mos. from seeds; sulphur passing into orange. Started in July plants bloom freely in pots in winter. Easily grown.

Walllower, Early Parisian, 1ft.; bloom in 4 mionths; fin? f, beds in Summer and pots in Winter; flowers a-

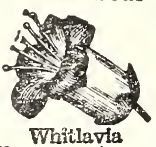

hundant, sweet-scented. Colors: Light Brown, Blood Red, Cream Yellcw, Yelow with black bud, separate or mixed. Whitlavia, Large-flowered, $1 \mathrm{ft}$. ver Whitlavia pretty annuals with lovely bell-shaped blue flowers throughout the season. Of easy culture. White, iature Gloxinia. Separate or mixed, 5 cents.
ZINNIA, Giant Dahlia-flwd.

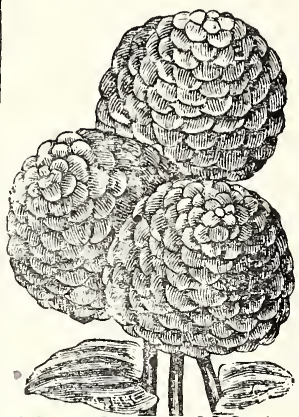

The Zinnia has been a favorite garden flower for years. I recall my boyish pleasure with the original single red Zinnia which I grew by the old garden walk. Then came the Double Zinnia in various colors, far surpassing it in beauty. But the Improved Dahliaflowered rivals the Dahlia in size, form and color, as also in showiness and beauty, while it thrives and displays a wealth of bloom in blazing sunshine and under other adverse conditions that would destroy the Dahlia. Plants are easily grown from seeds, begin to bloom early, and make a glorious display until the coming of severe frosts. We freely recommend this latest and best Zinnia. No garden annual excels it. Our seeds were saved by the specialists who developed these monster Zinnias, and are of surpassing quality.

NEW GIANT DAHLIA.FLOWERED ZINNIA

Exqusice, truly Dahlia-flowered in size and form, tyrian rose, fine. Crimson momarch, giant plants, flowers often 8in. across, glowing. Oricle, huge plants, large dble flowers; rich orange and gold.
Cream, the very best; free-blooming, big flowers, lavender blue, fine. Eutercep, immense plants, rich creamy yellow flowers; lovely.

FolarBear, immense chaste white double flowers, profusely borne. Other Splendidi Double Zinnias, Finest Quality

Pemila semi-dwarf, 1ft, lovely for beds, branching,very free-blooming: Colors: Whate, Rossta, 3ft., Benary's Special Mixture, very showy.
Crisma, 2ft, crested petals, double, very fine, very good for cutting. Achicvement, splendid quilled, very beautiful, rich colors, mixed. Achicvement, splendid quilled, very beautiful, rich cole.
Robrsta St: iata, $3 \mathrm{ft}$., large, exquisitely striped, double.

Grasilisma, ift, fiery scarlet, small flowers, fine in beds and for cutting Lislipus, lft, branching plants with small, double flowers, finest mxd.
Faageana-Perfec'ion, the lovely Mexican Zinnia, Finest mixed.

Stokesia Cyanea, 1ft, blue Fall Aster. Trifolium suaveolens, 1ft, rose, sweet. Tunica saxifraga, lilac, low edging. Symphyandra Hoffmannil, 1ft, white. Tritoma mirabilis, 3ft, Hybrids mixed Venidium calend. 2ft, golden daisies. Trachelium Coeruleum, 2 feet, blue. Tropaeolum minus, $18 \mathrm{in}$.for pots.red. Veronica Syriaca, $6 \mathrm{in}$. azure, for pots.

\section{Fine Ornamental GRASSES for Beds and Bouquets}

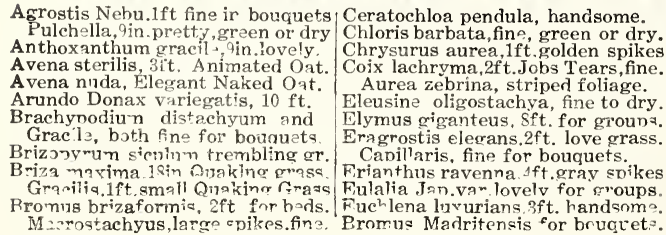

Festuca rigida,1ft. 'little comfry" Stipoides, Feather-like Fescue. Gymnothrix latifolia. $7 \mathrm{ft}$. nodding. Hordeum jubatum, Ift.squirrel tail Lagurus ovatus, $1 \mathrm{ft}$. silky heads. Panicum el+issimum, 6ft. Fuinea. rapillare,2ft. lovely in bonquets. Plicatum var creeping. showy. Sircatum. Palm-formed for pots
Virgatum. Eft. fine for beds. Pasnalum elegans $3 \mathrm{ft}$ ornamental. Pennisetum
Rueppelianum, $3 \mathrm{ft}$. fine bouquet. Poa pilosa,6in. for bouquet or bed. Polypogon monspeliensis, graceful Stipa pennata $5 \mathrm{ft}$, Feather grass. Sorghum halapense, $5 \mathrm{ft}$. showy. Nigrum, fine for bouquets. Tricholaena rosfa. $2 \mathrm{ft}$. beautiful. Uniola latifolia, $4 \mathrm{ft}$. fine for vases. Zea Japonica var.3ft.striped corn Quadricolor. 4 colored, 3ft. fine Perfecta gigantea, $5 \mathrm{ft}$. 4 colors.
Mixture of Zea $5 \mathrm{c}$.Grasses mxd.5c 


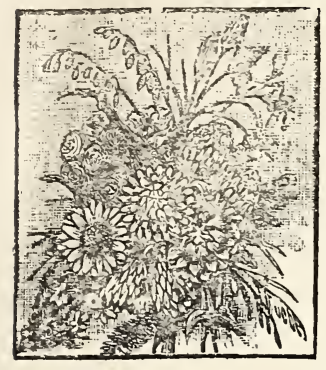

\section{EVERTSTINGS}

The Lverlastring have straw-like petals, and when cut and dricd in the shade, they retain their form and color, and can be used with dried Grasses in bouquet.s and designs for table decoration in winter. Some of them, as Acroclinium and Rhodanthe, should be cut just as they besin to open, to gut the best results; but Dou'le Helichrysum, Ammobium, Gomp'irena, Statice, Xeranthemum and others should remain until fully developed. All are easily grown fron seeds, and bloom the first season, being mostly annuals. Helichrysums and Gomphrenas are the most showy, and are usef it for a summer display in beds. The Gomphrena is nuch used in the South for cxo ed sunny beds, providing a rich display continuously

AiRoCLINIU.1, Graceful, siender plants, a foot hish, bearing continuously pretty daisy-like, dou'b'e flowers in abundance. A good everlasting. Double White, Rose; sep. or mixed 5 c.

AMMOBíJM alatum grandiflorum. a branching annual,two fe.t high; flowers double, pure white, freely borne during summer. It has winged stems and likes sandy soil. A splendid one.

CELOSIA spicata,two feet high, bear-

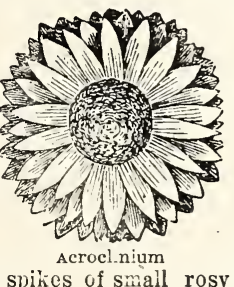

ing stiff, long spikes of small rosy flowers. A pretty annual, easily grown, useful in beds and for drying.

GNAPHALIUM foetidum, 2 feet, a composite annual; dense yellow heads

GOMPHRENA globosa, a beautiful annual from India. Floters globelike, freely produced, and very at-
tractive in beds or pots, and also, in tractive in beds or pots, and also, in
winter-bouquets. The plants are excellent for garden and greenhouse

Ammobium alatum a foot high, and set 8 inches apart cover the bel. The dwarfs, six in. high, are fine for pots and edgings. We offer Aurea superba, orange, White, Flesh, Rose Carmine, Striped; separate or in mixture, 5 cents. Nana Compacta, d.varf, very free-blooming; Carmine, White; separate or mixed. Dj not omit this splendid annual from your order.

GYPSO?HILA elegans, 18 in. Rose, Red, White, and Grandiffora White; very valuable for bouquets either green or dry. The varieties separate or in mixture 5 cents. We can also supply Gypsophila muralis, 6 in. lovely for edgings and carpets, and G. Paniculata, sin jlo and double, whits; also pure white.

HELIPTERUM Sanfordii, 1ft. the plants branching and bearing a head-like cluster of small chrome-yellow flowers at the tip of each branch. H. Corymbiflorum, white, yellow center.

Note. Helipterum and Rhodanthe, both lovely everlastings, are near relatives of Helichrysum, the most showy and beautiful of all flowers for drying. All are of easy culture, starting readily from seeds, and blooming abundantly the first season, being annuals. In Exrope, the Rhodanthe thrives well, and is much grown in pots, selling readily on the market.

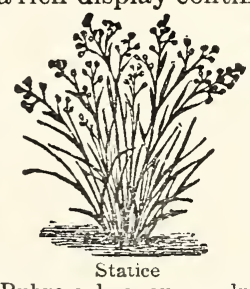

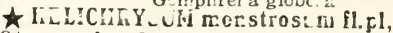
3 it. very handsome large doulle fowers; showy in the garden and the best of tie everlastings, retaining their form and bright colors perfectly when dry. We offer these fine rarieties; Album fl, pl. large white flowers. Borussorum Rex, pure white, fine. Roseum, lovely rose cclor; very good. Lutuom, clear shinirg yellow Purpureum, rich decp violct.

Rubro-salmoneum, salmon purple.

Sulphureum, lizht sul hur.

Fireball, fine scarlet with orange. Fuscatum, dark brown.

Aurea, golden ycllow; splendid,

The above fine named kinds were saved from choice double floweis and will give the best results. $5 \mathrm{c}$.

LONAS inodora, $1 \mathrm{ft}$. small yellow flowers in dense terminal heads.

MOLUCELLA laevis.2it. fragrant

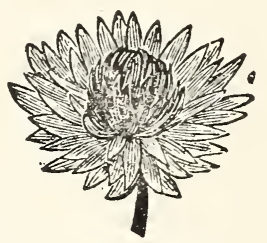

Xeran themum

white flowers in whorls; the pes sistent shell-like calyx, curous and attractive; retains its form and culor when ary.

PHYSALIS Franchetti, Chinese Lantern, large oranze baloon like fruits in long racemes; eäible wlen iresh; beautiful, P0LYCOLYMNA Stuartii, 2it. white, easily grown.

RHODANTHE, pretty annuals, graceful aster-like flcwers; fine pot plants for the plant-stand or for market; gcod for drying. Manglesii; rose, white, mixeà; Maculata, rcse, white and mixed. Separate or in complete mixture, $5 \mathrm{cis}$,

STATICE, Sea Laverder, many kinds; all prized for touquets either green or dry. We offer the best varieties: Bonduellii, 2ft, yellowish. |Sinensis, white and yellew. Incana nana, $1 \mathrm{ft}$. fine mised. Sinuata, $2 \mathrm{ft}$. cloice by krids Latifolia, 2ft. blue, sclendid. Spicata, 2ft. lilac red, fre. Macrophylla, 2ft. dark blue. Suworowii, 2ft, bright roso.

The above varieties separate or in complete mixture. 5 cts. XERANTHEMUM, 2ft beautiful easily-zrown annuals; showy in beds and excellent for drying. Flow ers large, full-donble a in of lovely colors. Douhle Imperial, Dark Red, Rose, White and mixed. Separate or all in complete mixture. 5 cts.

\section{CULINARY AND MEDICINAL GARDEN HERBS}

\section{Angelica archangelica, $5 \mathrm{ft}$. biennial; large leaves; big umbels Fennel, 5it, biennial, fine fraglant foliage; used as salad.} of small white flowers. When steeped, the roots and seeds Horehound, 2ft, per, a bitter root usid for cough remedy. yield an aromatic tonic. In Lapland it is use 1 as a condiment. .yssop, $2 \mathrm{ft}$, per. ornamental mint and pot herb; expectorant. Anise, 1ft. annual; umbels of white bloom; seefls used for Lavender,2it, per. flowers blue, plant delightfully scented, tlavoring; also for tea to relieve colic; delightfully fragrant. Lovage, ift, per. White umbels: seeds aromatic; a potherb. Artemisia vul. Mugwort, $4 \mathrm{ft}$. prennial; pretty fragrant fol. Basil, Sweet Purple Bush, 1ft. annual; leaves used in soups. Balm. Melissa, 2ft, perennial; lemon flavor, whitish bloom. Borage, 2ft, perennial; blue, white, drooving; used for drinks. Caraway, 1ft. biennial; white umbels, fragrant seeds.

Catnip, 2ft. per. tea from the tops aids digestion; bee pasture. Coriander, 2ft. annual, white umbels: seeds used to flavor. Cumin, 6in, annual, rosv-white umbels: seeds used to flavor Dandelion, 6in, verv showr golden bloom; salads in spring

Improved Broad-leaved. early; fine winter salad if forced. Majorum, Sweet, 2ft, annual plants used for flavoring.

Majorum, Pct, 2ft. per. grown in pots; branches culinary, Pernyroyal, Mentha Pulegium, Sin. lilac bloom; aromatic. Rosemary, ever $r$ reen shrub, 3ft, leaves used for seasoning. Sage.Broad-leaved, 1ft, sutb-shrub; leaves used in cockirg. Savory, Summer. 1it, annual, flowers lilac, leaves for seas'ng. Savory. Winter, $1 \mathrm{ft}$. sub-shrub, rale purple: used to faror. Tansv. Garuen, 2ft. per. in old gardens: mossy foliage. Thyme, French. 6in. sub-shrub. rose-purple: aromatic $n$ irt Thvme Winter. Broad-leaved, lemon:leaves priced in Dill, Anethum, $2 \mathrm{ft}$, biennial. yellowish umbels. seeds as flavor. Complete Herb Mixture, 5 certs; separate, 5 cents. 


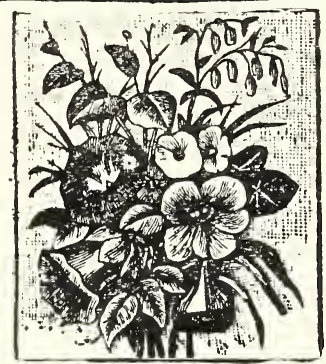

\section{Ornamental Vines}

B

eds of flowers tastefully disposed give. brightness and beauty to a place, but it is the Climbers that 1 hey teautify unsigend sptcial charm to a home. otony of the giounds; they supply, like Jonah's gourd, quick shade fiom the burning sl.n. A good variety of these plants should be found at every home. They are indispensable in giving a homey appearance, and imparting cheer and comfort and contentment to the inmates. The plants are readily started from seeds, and easily transplanted to where you wish them to grow.

Furnish support as soon as they begin to run. Complete Special Mixture, 5 cts.

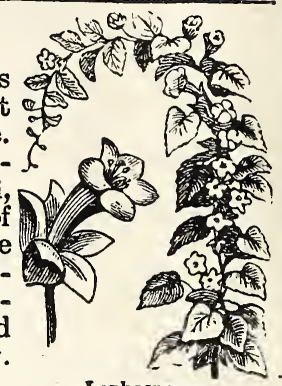

Lophospermum

\section{BEAN, Improved Scarlet Runner}

An easily-grown, ro'bust vine, bearing freely large clusters of rich, showy, scarlet bloom, followed by big pols of large edible beans. Pick before ripe to promote a continued bloom. They are, besides, much more palatable if used when green. Oz. 10 cts. Packet 5 c.

Bryon ipsis Laciniosa A lovely rapid vine of the Gourd family; flowers small fruits

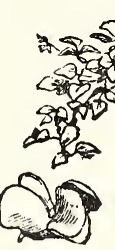
$\frac{2 \pi}{20}$ 40 A sq green, with brown blotches; a fine climber. 5 cts.

BE VIVCASA Cerifera, robust vine, with large leaves and big showy yellow flowers four inches across, followed by attrastive white fruits that are good for preserves and pickles.

BRYONIA Dioica, strong-climbing, large-leaved perennial harbazeo'ss vin 3 with tuberous roots; flowers small, greenishwhite, s'icceeded by red berry-like fruits. 5 cents.

CALA 1PELIS Scabra a climbing shrub, bearing scarlet, carmine or golden racemes of bloom the first year; an elegant vine for walls, pillars or trellises. Colors sep. or mixed.

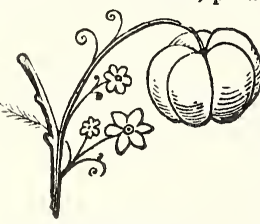

CARDIOSPERMUM, pretty graceful vines $15 \mathrm{ft}$. Flowers small; see
vessels balloon-like; handsome. Halicacabum, smooth stems, 5 cts. Hirsutum, hairy stems, 5 cts. All mixed, 5 cts. A lovely perennial, but usually grown as an annual.

CARDINAL Climber, 20ft, a hybrid Ipomoea similar to Cypress Cardiospermum Vine. A good trellis vine. 5 cts.

CAJOPHORA lateritia, 5ft, a handsome annual; brick-red, + COBAEA scandens, 20ft, the beautiful "Cup and Saucer Vine"; flowers large purple cups; also white; attractive foliage; one of our best climbers. Separate or mixed. $5 \mathrm{cts}$.

COBAEA macrostemma, rapid growin? vine with charming fliage; flowers green,violet tipped; new and interesting, 5cts. Coviolvulus, Morning Glory, Large-flowered; the old sort inproved: flowers unsurpassed in beauty and profusion; should be at every home. White, White with rose, White striped rose, White striped violet. Flesh, Carmine, Rich Dark Red, Light Blue, Iilac, Black Blue; sep. or in fine mixture. Dosble-flowered and semi-double in splendid mixture. 5 cents.

Aureus superbus, the charming golden Morning Glory; new and beautiful; 5 cts.

CANARY Vine, $15 \mathrm{ft}$, a lovely vine: flowers yellow, resembling a canary bird.

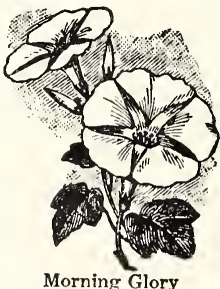

Ci) Morning Glory rnots and navv blue flowers; Sellowiana has large cobalt blue flowers: hoth are handsome. Senarate or mixed, 5 cts.

CENTROSEMA grandiflora, Butterfly Pea, red flowers.
CLITORIA ternatea, $5 \mathrm{ft}$, beautiful royal blue flowers: rare COCCINEA indica, 6ft, large white bell-flowers; red fruits DOLICHOS, Hyacinth Bean, easily grown bean-like vines, useful for covering fences or small buildings; flowers deep purple and white; either color or mixed, 5 cts. Giant Japan Dark Red, Darkness; also Giant White, Daylight: Texas Giant, violet-red. Complete mixture of above sorts, $5 \mathrm{cts}$.

\section{Gourcis in variety}

The Gourd family embraces a great variety of flowers with fruits that are wonderfully interesting. Some are prized for their foliage, some for their flowers, and others for their interesting fruits, which are of many sizes, colors and variegations, all ornamental, and some desirable for food. We urge our friends to get at least some mixed seeds of gourds and cucumbers. They will afford much satisfacticn and pleasure. LAGENARIA Vulgaris. This class includes the Diprer Gousd, Bottle Gourd and others. Vines 20 to $30 \mathrm{ft}$; fow ers w hite, handsome and having the perfume of musk. We can suprly Siphon or Dipper, large fruits with a long handhe; used for drinking dippers, bird houses, etc, Hercules Club. long slim fruits, $5 \mathrm{ft}$, showy, edible, Bottle Gourd, very large, bottieshaped, with necks. Powder Horn, large, horn-shape. Sugar Trough, large, spherical, used for sugar troughs, lard cans.t tc, Corsican, or Dish, large depressed fruits; fine for receptacles Enormis, immense fruits, odd and useful, Minima, very small; used for pipes and toys; sep. or mixed, 5 ets. a pkt.

Cucurbita ovifera, the small, fancy, hard-shellea gourds used as children's toys; yellow bloom; 6ft, Bicolor, green and gold; charming, Miniature, round, dark green; gold-striped, Orange, resembling a citr"s fruit, E\&g shaped, white, Japan, used for nest eggs, Depressa, flat; dark green striped yellow, Apple Gourd, early, pure white, pretty, Pear Gourd, yellow ringed green. Pear striped, green with longitudinal white bands. Pear-shaped, white, handsome. These small fancy gourds, separate or mixed, $5 \mathrm{cts}$, Nothing amuses children more than a collection of these fancy little gourds,

Cucurbita ficifolia, the beautiful Malabar Melon, prized for its foliage and large, globular showy fruits, green striped white Cucurbita Maxima, Giant Pumpkins, Very Large Tours, often $100 \mathrm{lbs}$, gray-green with deeper markings; edible, Potiron Globe, pale yellow, largest of Pumpkins; keeps well and is of good flavor, Etampes, large, slightly flattened; flosh thick, orange, sweet and of excellent quality; skin, bright orange-red, beautiful, Gray Boulogne, fruit gray, often $3 \mathrm{ft}$, across; the flesh thick and good, Mammoth White,

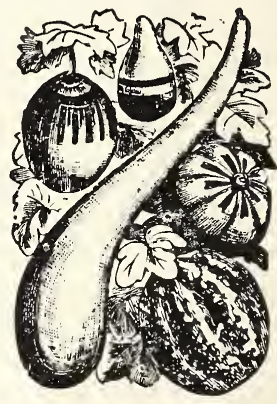

large, pale or cream flesh, King of Mammoths, very large, productive. These Giant Pumpkins are all edible as well as showy and ornamental, Senarate or mixed, $5 \mathrm{cts}$, a packet, Cucurbita argyrosperma, the interesting Silver-seeded Gourd, CUCUMIS flexuosus, the Snake Cucumber, often $3 \mathrm{ft}$, long, colled to resemble a snake; A curious ground vine; Dudaim is another cucumber not unlike an orange in shape and color, and dolicionsly sennted; grown for its perfume,

CYCLANTHERA, 10ft. vizorous, with handsome foliage; fast grower, Explodens has egg-like fruit that explodes when ripe, Pedata is similar; both have edible fruits; sep, or mixed. 
Tie Gourd Family, continued

ECBALLIJ.A eiaterium, Squirting cucumber, a trailing perennial; Howers yellow, bell-shaped, an inch across; fruit 2 in. long, violently ejecting the seeds when ripe, $5 \mathrm{cts}$,

ECHINOCYSTIS lobata, Wild Cucumber; $30 \mathrm{ft}$, a graceful, rapil-growing vine with curious fruits; likes moist soil,

LUFFA, the Dish-rag Gourd, a handsome vine in foliage, flowers and fruit; vigorous and always admired; fruits used as dish rags, Acutangula, golden flowers, large fruits; beautiful; Macrocarpa, large s.nooth fruits; Marylandica, also Cylindrica, both handsome sorts; Sooly Qua has pretty small fruits, All thase handsome Luffas, separate or mixed, $5 \mathrm{cts}$,

MJMORJICA, Balsam Apple, a pretty vine $6 \mathrm{ft}$, bearing showy red fruits the size of an egg, Charantia, Balsam Pear, pear-shapod, red; fruits of both are used for making a salve,

TRICHOSANTHES anguinea, Serpent Gourd, a climbing annual; flowers white, 2in, across, showy; fruits slim, $5 \mathrm{ft}$, long, twisted, snake-like, edible; a handsome rine, T. Colubrina; known as Viper Gourd, is the same vine, $5 \mathrm{cts}$, a pkt,

HUMULUS Japonicus variegatis, a free-growing climber with light green leaves distinctly edged white; a grand vine for covering any unsightly objects, or for shade; easily grown,

\section{IPOMOEAS}

Ipomueas are among the most desirable of vines, They start readily from seeds, grow rapidly, bloom throughout the summer, and are hardly surpassed for covering old walls, buildings or trellises, Give stroag support early. We offer the following splendid kinds: Bona Nox, the Evening Glory, a vigorous vine with showy rosy violet flowers. Coccizea, a smooth, handsome vine of quick growth; flowers orangescarlet, like Cypress Vine, lasting t'iroug'sout the day; very beautiful, Granuiflora alba, Moonvine, rapid and free-blooming; large, white, frimrant flrwers; a splendid vine, Black seeded, $5 c$, White seeded, $5 \mathrm{c}$, Hederacea, the handsome Ivy. leaved; beautiful sky-blue flowers. Huberi, variegated Ieaves; mxd. Inperialis, the Japanese Imperial Morning Glory; robust vines of easy culture; fiowers like our Morning Glory but larger, more vari 3 d in color and variegation, and free blooming. Our seeds are of

fine new giant varieties, and are sure to please; mixed, 5 cts,

Leari, intensely dark blue; a splendid perennial which white. Mexicana, a tuberous-rooted vine with blue, edged

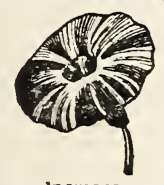

Ipomoea

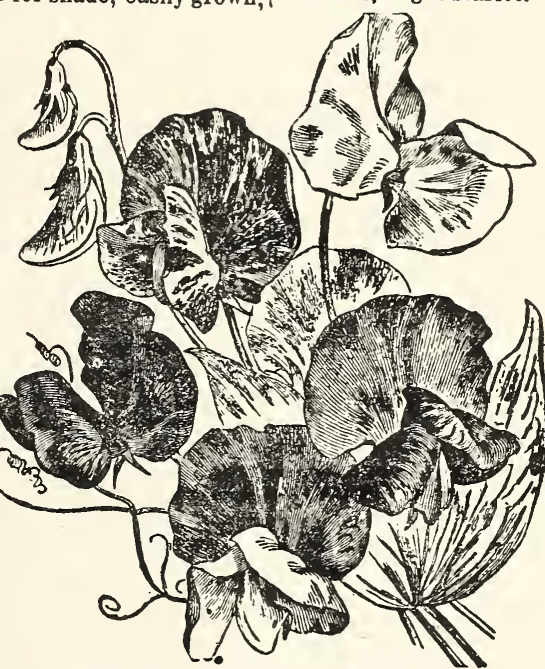

new, best varieties in all colors, Those starred were lately Firefly, bright yellow, with cardinal spots, calyz and spur red.

Gold Queen, sunflower yellow.

Gunther's Hybrids, mixed colors.

Ivy-leaved, be autiful,mixed colors. Jupiter, pure orange, showy,

Kermesina, fine crimson.

Victoria Louise, cream, red spots. Edw. Otto, bronze, silky lustre. Ruby, blush rose, shaded; new. Schillingi, yellow, red spots.

Twilight, chamois, rosy salmon tint. Tom Pounce, tralling, mixed hues. Complete mixture, oz. 18c., half oz. $10 c .$, pkt. $5 c$ Sep. same price.

\section{SWEET PEAS}

Special complete mixture of all sorts. oz 12 cts. pkt 60 to 75 seeds, 5 cts.
These are among the most beautiful and satisfactory of garden flow. ers, and of easy cuiture The vines grow ten feet high in rich soil, and are literally covered wtth bright long-stemmed flowers, richly scented, and exquisite for garden, room and personal adornment. If you grow but a half dozen annuals let the improved Sweet Peas be one of them. Our collection embraces the

perennial vine with silvery foliage anu rarso vivasar rosy bells. Biooms first season, and useful for indoor or outdoor uliurt. See Engraving on opposite page. 5 cts.

MAURANDYA, a beautiful vine, the foliage abundant and graceful. the flowers numerous and charming; grows 6 feet high, and is admirable for a screen or trellis. Rose, Crimson, urple and White, separate or mixed $5 \mathrm{c}$,

MINA lobata, charming rapid climber, rich scarlet bioom, $5 \mathrm{c}$. NASTURTIUM, Glant Fragrant.

The old-fashioned Nasturtiums of our childhood have been greatly improved, but they still recall the hallowed associations of by-gone days. The vines are stronger, the flowers larger and fragrant, and the colors and markings more varied. The foliage, too, shows different graceful forms, and charming variegations. We offer the finest up-to-date sorts, that will be a revelation to persons acquainted only with common Nasturtiums. Mixture of all, 10z. 18c, half oz. 10c, pkt. 5c, Asa Gray, creamy white. Atropurpurea, dark red. Battles, salmon, red spots. Black Prince, dark purple.
Brflliant, bright scarlet.

Fimbriatum, fringed, mixt cols Butterfly, yellow, salmon spots Chameleon, variable colors.

Cloth of Gold. fire red gold leaf chosen by a committee of the National Sweet Pea Society of Lngland as the best varieties in their color. Our Special Comof lovely lilac bloom; cottony seeds. Nil Grandiflora, a graceful vine with large bell-shared blue flowers: pretty. Quamoclit, Cypress Vine, a tall, rapid vine with fern-like foliage; flowers small, profuse, always open; Red, White, Rose, Separate or the colors mixed, 5 cts? Rubro-coerulea grandiflora, the early-towering sort, bears a wealth of exquisite heavenly blue flowers, also White; either color or mixed, 5 cts.

Sanguinea, free growth, pretty foliage, deep scarlet flower. Scarletina, a lovely vine; cinnabar red bloom.

Seloia, Brazilian Morning Glory, large, rose flowers Violacea vera is same as Rubro-coerulea. Complete mixture
of all Ipomœas, 5 cts. LAT HYRUS Azureus, Lord Anson's
Pea, a strong-growing vine bearing bluish-purple flowers on long manyflowered stems.

Rosundiflorus, $10 \mathrm{ft}$. coppery red.large, horne unon long, many-flow'd stems. Tingitanus, 6ft. large purplestandard, keel bright red. A handsome annual. I.0 ASA. see Caiophora. 5 cts.

LOPHOSPERMUM Scandens, a lovely

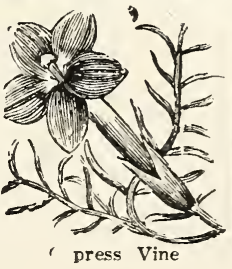

press Vine plete Mixture contains all our Spencer and Grandiflora var-
ieties. Price 1-4 lb. 40 cts., oz. 12 cts pkt. 60 to 75 seeds, 5c, $\downarrow$ The Best Giant Spencers

We offer the Best Giant Spencers, varieties chosen by the National Swcet Pea Society of England as the Best in their respective class. You make no mistake in getting these, They represent all the fre colors and variegations,

BIue Picotee. whiteedged blue/Mary Pickford, pink and salm'n Charming, dazzl'g cerise wav'd Matchless rich cream, frilled. Com. Goodsall, violet blue, fme Miss Calif., pmk, salmon tinge Constance Hinton, giant white Mrs. Cuthb rose, white wings Crimson King, richest crimson Mrs. T, Jones, delphınıum blue Daisybud, deep apple-blossom. Powerscourt, superb lavender. Fair Maid, blush, shad'd salm'n Royal Purple, glorious purple. Hawlmark, lavender, clear. Sunset, like a rích evn'g glow. Hau Imark, vivid scarlet, fine. Tangerine, vivid dark orange. Hercules. giant fine pink, Valentine, splendid shell punk. Jean Ireland, cream, red edge. Wiarrior, giant. rich maroon,

The Giant Spencer Sweet Peas in complete spocial mixture, embracing all the above best sorts $\mathrm{m}$ careful proportion, $1 / 4$ lb. 55 cts.; oz. 15 cts.: pkt. 40 to 50 seeds, 5c. Separate varieties same price. The full collection, $22 \mathrm{pkts}$. only $\$ 1.00$.

Please Note. We prepare but one blend of Giant Spencers, and that is the best that can ie made. They will delight you. This blend is prepared by us with great care and is unexcelled. Sweet Peas continued on nezt page. 


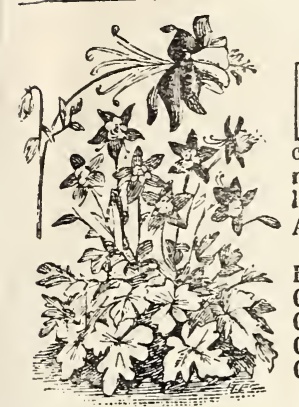

Aquilegia Coerulea

\section{AQUILEGIA, the Beautisul COLUMBINE}

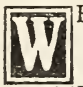
E HAVE a splendid collection of these graceful, showy and beautiful perennials. All are hardy, easily grown, free-blooming, and greatly admired. Don't fail to start a bed of them this year. They delight in moist soil and partial shade. The Columbines are often called Honeysuckles, because their long spurs contain honey, and are frequently visited by hun:ming birds and buttertlics to obtain the treasured sweet. Some bear double flowers, but the long-spurred single kinds are realiy more graceful and beautiful. All are deserving of culture.

Alpina, 1ft. blue flowers 3 in. across, two or three on a stem; from Swiss Alps; likes shade; fine. Superba, a new superb variety, deep blue and white in striking contrast; magnificent. Baicalensis, 2 ft. beautiful blue with snow-white corolla; a handsome and desirable Columbine. Californica hybrida, $3 \mathrm{ft}$. sepals and petals tinged orange, long, carmine-lake spurs; beautiful. Canadensis,1ft. old rose and golden yellow, nodding; very graceful; early spring; splendid. Caryophylloides fl. pl. $2 \mathrm{ft}$. beautiful striped varieties, the flower large and double, mixed, $5 \mathrm{c}$ Chrysantha, $3 \mathrm{ft}$, chrome yellow, long spurs, blooms all summer; one of our finest perennials. Grandiflora alba, a sort with lovely large snow-white bloom; new and charming.

Double-fiowered, a variety with large, double, golden yellow flowers; best of double Columbines. Coerulea, 2it. Rocky Mountain Columbine; sky blue with Jaetschaui, 3ft.large golden blooms with peach-red spurs. white corolla, one of our liveliest flowers.

Citrina, lemon yellow, long spurs. Rose Queen, rich rose, white corolla; Double-flowered, white, yellow and blue.

Erecta nana a trovioiacea, ift a choice double violet-blue sort. Flabellata nana, 1fto nodding pure white tlowers; beds or pots. For nusa, 2 it. large, double, blue flowers; nodding, graceful. Glandulosa, 1ft. very large, nodding; lilac blue, white tips. Haylodgensis, 2ft. long-spurred hybrids, mixed colors. Helenae. $2 \mathrm{ft}$. large flowers, violet blue with snowy corolla. Hybrida monstrosa, 2ft compact plant of fine double flowers. Vernalis, 2ft early; semi-double flowers, some long-spurred. Nivea grandiflora, $3 \mathrm{ft}$. pure white, large. semi-double. Olympica,3ft. big blue flowers with lovely white corolla. Scott EIliott's Long-spurred hybrids, mixed colors; splendıd. Siberica, 1ft. large, double; Blue, Rose, Red; sep, or mixed. Skinnerii, 2ft. red spurs, yellowish corolla, free-blooming. Stellata fi. pl. $3 \mathrm{ft}$. double, erect flowers in abundance, mixed. Truncata, 3ft, old rose with yellow; a very beautiful sort. Vervaneana fl. pl. $3 \mathrm{ft}$. rosy-lilac flowers, variegated foliage. Vulgaris, 2ft. dbl. Alba, white; Rosea, rose; Striped; sep. mxd. Our Sbecial Mixture of Long-spurred Columbines, 5 cts. Complete Special Mixture of all our choice Columbines, $5 \mathrm{c}$.

AjTER alpinus $1 \mathrm{ft}$. beautiful, large, free-blooming, mixed. BAPTISIA australis, $4 \mathrm{ft}$. azure, pea-like flowers in racemes.

Alpinus Goliath, 2ft. largest flowers, soft blue; handsome. Amellus, 2ft. a flne large aster, mostly blue and rose shades. Cassubicus grandiflorus, $2 \mathrm{ft}$. large lavender-blue flowers. Diplostephioides, sub-coeruleus, 1ft. large, light blue; very beautiful; does well in pots as well as beds; a fine variety. Complete Mixture of all varieties, 5 cents.

ASTER Perennial, 3ft. large-flowered; splendid branching jlants that bloom the first season, and continue to make a fina display every autumn for several years; mixed, $5 \mathrm{c}$. Snowflake, a hardy aster with large, pnre white single flowers Horizontalis, $3 \mathrm{ft}$. large flowers upon horizontal branches.

\section{BOCCONIA cordata, 8ft. Plume Poppy, big panicles of chamois} flowers; very large, heart-shaped 7-lobed leaves; handsome. Microcarpa, 9it. amber buds, buff flowers; tall and showy. Thunbergii, 7ft. flesh-colored buds, coffee-colored flowers, red-vemed foliage; one of the handsomest of Bocconias. BUPHTHALMUM salicifolium, 2ft. composite, large yellow heads, willow-like foliage; showy, hardy, ornamental pern'l. CATANANCHE coerulea, 3 ft. a fine perennial; flowers composite, 2 inches across, borne on long stems; fine for cutting and valuable as an everlasting; should be better known.

Bicolor, like Coerulea, butwith pretty two-colored fowers.

\section{CAMPANULA MEDIUM, Cariterburg Bells}

The beauty of the Improved Canterbury Bell can hardly be excelled. The blants grow more than two feet high, are symmetrical, and become little pyramidal "trees" literally covered with the big exquisite bells, making a glorious display. The texture of the flowers is charm-
ing and the colors, white and blue and rose and purple, afford a display that aurpasses many of the other garden beds. The plants are easily started and easily grown, and are always a source of extreme pleasure when in bloom. Do not forget them.

Canterbury Bell. Single-flowered, Pure White, Lilac, Deep Lilac, Rose. Rosy Carmine, Striped and inght Blue; separate or in well-proportioned mixture, 5 cents.

Canterbury Bell. Double-flowered, Blue, Pure White, Lilac, Deep Lilac, Rose, Rosy Carm.n. Striata, Light Blue, Syringa Blue: separate or mixed, 5 cents.

Canterbury Bell. Cup and Saucer, (Calycanthema) Blue, Pure White, Rose, Striped, Rosy Carmme. I!!acina and Deep Lilac; separate or mixed, 5 cents.

recox, esriv thowsring, $3 \mathrm{ft}$. Blue, White, Rose, Striped; separate or mixed, 5 cts.

Complete Special Mrxture of all Single, Double, Cup and Sa

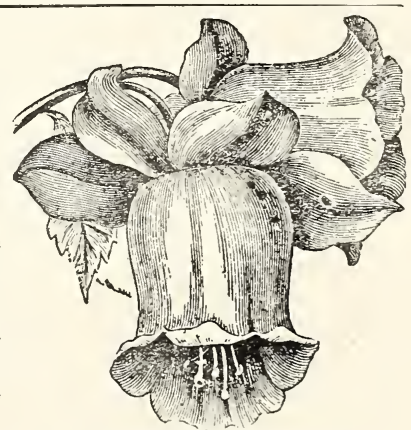

The beautiful Canterbury Bell

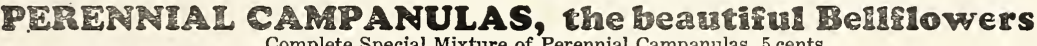

The Canterbury Bells are biennials, the plants developing|Michauxioides, $5 \mathrm{ft}$. azure, nodding flowers, showy in borders. the first year and blooming the second, then dying. Once Mirabilis, 2ft. pyramidal; light blue, large bells; beautiful. started, however, they will mostly renew the bed from self- Persicifolia alba, 2ft. large, broad bells in racemes; splendid. sown seeds But the following Campanulas or Bellflowers are Coerulea grandiflora, 2ft, blue, very large, open bells; fine. haidy peiennials, and will retain their place in the garden ior years Many of these are particularly desirable perennials. Alharifolia, 2ft. white, rather broad bells with fringed edge. Barbata, 1ft. tufted; azure, in loose racemes; rockery, June. Carpatica, 1ft large, open bells, vivid blue, long stems; fine. Alba, like blue-flowered, but with pure white flowers. Both Carpaticas are splendid plants for the rock garden; profuse. Garganica, 6in. blue, open, drooping: fine for baskets: summer. Grandis, 3it. violet-blue, large, shory, broadly bell-shaped. Latifolia alba, $2 \mathrm{ft}$. large, funnel-shaped bells; free-bloom beds Alba. a handsome white-flowered variety. Both splendid.
Maerantha, 3 it. blue. large flowers; fine for borders;also White. Campanula, Perennial sorts, mixed; Complete Mixture of all. 


\section{CARN.ATION, Hardy Garden}

T HE HARDY CARNATIONS have been favorite flowers for centuries, and today they are as popular as ever. They have been greatly improved, the flowers now being mostly double, of large size and deliciously fragrant, being alike, desirable for garden or room decoration. The plants are easily grown from seeds, are hardy, and once established in a garden bed will last for several years. They show many fine colors.

CaAABAD, Perpetual Giant, the most desirable of Carnations, the flowers being of great size, fine form, rich and varied colurs and deliciously fragrant, The seeds here offered are tine named varieties from a French specialist and are unsurpassed, the colors coming true trom seeds, and giving 90 per cent of big double flowers. Pkt. 25 to 30 seeds, $5 \mathrm{c}$. Jeanne Dionis, pure snow white. Reine Rose, cochineal carmine.

Marie Chabaud, sulphur yellow.

Magenta, vivid dark red.

La Perle, rosy mauve.

Legion d'Honneur, copper red.

Rubis, rich ruby red.

Nero, dark blood red.

Firefly, bright scarlet.

Reine Rose Pale, pale rosy lilac.

Comtesse de Paris, pure yellow.

Complete Special Mixture of the above, Finest Quality, 25 to 30 seeds, $5 \mathrm{c}$.

EARLIEST Dwarf Vienna, 14 in. high, flowers very double; Benary's Improved Strain, very superior; White, Rose and Violet coiors in mixture, 5c.

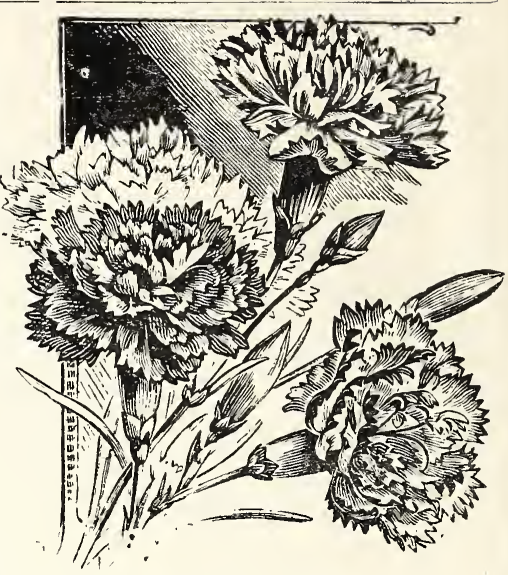

Hardy Garden Carnation
GIANT Malmaison, very large, double, fragant flowers; fine English and French seeds specially mixed, 5 cts.

GRENADIN, 14 in. large, double, sweet-scented, scarlet fl'rs. KING of the Blacks, double, fragraut; beautiful dark shades. MONT Blanc, double, fragrant, pure white; fine for cutting. $\star$ Fine Special Mixture of Grenadin Carnations, $5 \mathrm{cts}$. MARGARET, Benary's Improved, 18in. large. very double and fragrant; very charming varieties in the foliowing colors.

CEDRONELLA cana. $2 \mathrm{ft}$. a neat hardy evergreen mint; pretty, crimson, s weet-scented flowers in numerous spikes; showy.

CENTAUREA macrocepiala, 3ft. large, golden yellow heads. Montana, 2ft. superb, large corn-flower blue flowers; Spring. CEPHALARIA AIpina, 8ft. scabiosa-like; lovely sulphur bloom. Tartarica, $7 \mathrm{ft}$. rather coarse, but bas showy yellow heads. CERAS IIUM Biebersteini, 1ft. silvery foliage; daisy-like white flowers, long stem. Makes a showy bed, and is fine for edges. Tomentosum, 1ft. white leaves and abundant flowers.

CHAMAEPE UCE diacantha, $4 \mathrm{ft}$.deep lilac, spiny, striped foliage. CHEIRANTHUS Allionii,2ft. bright orange-yellow, fine clusters CHELONE Coccinea, $4 \mathrm{ft}$. allied to Pentstemon; very slender scarlet tubular flowers in abundance; a fine perennial.

CIRSIUM pulcherrimum, $3 \mathrm{ft}$. pretty thistle, large lilac fl'rs. Velenowskyi, $3 \mathrm{ft}$. ornamental f'rs; white changing to violet. CLEMATIS cory mbosa, $10 \mathrm{ft}$. flowers in corymbs; hardy pern'l. Crispa, 4 ft. a slender vine; flowers nodding; pale lilac; rare. Flammula, $20 \mathrm{ft}$. a slender, robnst vine; panieles of pretty
White, Dark Red, Rose, Scarler, Viole.t, Yure Yellow, Yellow ground; separate or in splendid Special hixinre. This strain should not be confused with the Margaret Cainations off 1 ed by many seedsmen. There is nothing better.

HaRDY BORDER Carnations and Pícotees. A high class strain saved by a French specialist; plants con pact, free blooming, hardy; flowers full-double, richly scented and embracing the most brilliant and distinct hues and tints.

white, fragrant flowers freely borne from July fill Oct.

Integrifolia, 25t., not a vine; flowers lavende $r$ blue, nodding, Jackmanii, 10ft. big purple firs; profuse; hardy but "miffy . Paniculata, 20ft. white, fragrant fl'rs in great profusion, fine. Recta, 5ft. not a vine; sweet white fl'rs in dense corymbs. Virginiana, 20ft. flowers white, fragrant, panicled; protty.

Vitalba, $20 \mathrm{ft}$. fl. white, almond scented; pretty robust vine. Complete Special Mixture of Clemetis, 5 cts.

CINERARIA Diamond, $1 \mathrm{ft}$. silvery foliage; yellow flr.; edging. COLCHICUM autumnale, $1 \mathrm{ft}$. pretty rosy-lílac fl'rs. in autumn. CONVOLVULUS altheoides, $5 \mathrm{ft}$. vine; fl.violet, 2 in. across, fine; blooms continuously from June until October.

CORONILLA varia, 3ft. fl'rs pink in dense umbels, support.

CRUCIANE LLA stylosa, $1 \mathrm{ft}$. small pink tubular fl. in heads; fine rock plant, blooms first season. but is a hardy las ting pern'l. COREOPSIS grandiflora, 3ft. a fine, everblooming perenniak, has long-stemmed golden flowers, showy in the garden, and fine for cutting; rich and excellent for groups.

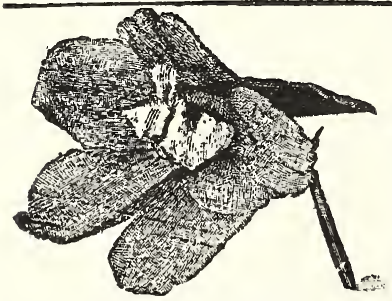

Flower of Delphinlum

\section{DELPHINIUM, the glorious Ferennial Larkspur \\ Complete Special Mixture of Per ennial Larkspurs, 5 cts}

These are among the finest of garden flowers. All are beautiful, freeblooming, and showy, the prevailing colors being exquisite rich shades of blue. They are, as a rule, easily grown, and last for years when once es. tablished. We offer the finest seeds obtainable. Separate or mixed, 5c.

Barlowii, 4ft, large-flowered, navy blue.

Caucasicum, 5ft. sky-blue, white center.

Elatum, large-fi. hybrids, $6 \mathrm{ft}$ finest mixed.

Large-fl. hybrids, light blue shades. charmıng,

Dark blue shades in splendid mixture.

Nanum, $4 \mathrm{ft}$. Benary's new semi-dwarf varieties, mixed. Formosum, 2ft, dark blue, large, beautiful, Sibericum, $2 \mathrm{ft}$, blue shades, large flowers, Speciosum, dark blue, sweet-scented flowers. Staphysagria, 2ft, dark blue, white eye, Truncatum $5 \mathrm{ft}$, dark blue, showy flowers, Complete Splendid Mixture of all choice Delphiniums listed above. 5c, Do not omit these,

\section{DIGITAIIS, the charming Foxgloves}

Lutzii, 4ft, new salmon-rose varieties; beautiful, Ferruginea, 5fi, giant, yellow, veined brown, lvory's Spotted, $4 \mathrm{ft}$, large bells, richly spotted. Monstrosa, 3ft. large, open $\mathrm{fl}$, at top of truss, Purpurea, $4 \mathrm{ft}$, the common Foxglove, mixed, Grandiflora, 3ft, chrome yellow, large. peren'l, Gloxiniæflora, $4 \mathrm{ft}$, big trusses of Gloxinia-like $\star$ THE SHIRLEY, considered the finest; 6 to $9 \mathrm{ft}$, tall, the stems thickly set with huge droopin gloxinia-like flowers in all the colors ranging from white to deep rose; magnificent. 5 cts, NOTE, Foxgloves are fine hardy biennials bearing showy and graceful bells of various colors and exquisite variegations. See engraving. The plants are easily grown from seeds, and are beautiful in beds or borders. Often the display in the garden is kept up by voluntary seedlings. The new Shirley Foxglove developed bv and displaying the lovely flowers in long, showy, erect racemes. Don't fail to try it. Hybridum fl, pl, Benary's choice dbl, mix, ladonna, light and dark blue shades,

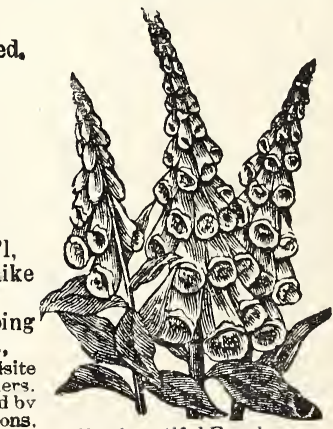

The beautiful Foxgloves 


\section{HOLLYHOCK, Improved Double}

W. $\mathrm{E}$ TAKE pleasure in offeling the finest strain of Double Hollyhock, Chaters Improved. This fine strain, grown by Mr. Benary and called "Benary's Prize", is not surpassed, the flowers being very large, full-double, and richly fringed, while the colors are simply wonderful. We also have Vilmorin's Extra Fine Double Hollyhock, imported direct from the growers in Paris. Either of these splendid strains will please you. Ciet a mixed packet of each. Our mixtures are carefully prepared from our splendid varicties and will yield all the fine colors. Only 5 cts. a packet, separate or in well-proportioncd mixture. Benary's Prize: White, Sulphur, Golden Yellow, Kose, Scarlet, Crimson, White tinted rose, Cream, Peach, Apricot, Chamois, Dark Rose, Salmon-rose, Carmine, Light Red in yellow ground, Dark Salmon-red, and Honyhock Apricot, Chas
urplish Violet. Complete Special Mixture of all Benary's Hollyhocks, 5 cents.

Vilmorin's Extra Fine: White, White with blue eye, Crimson, Sulphur Yellow, Peach Blnssom, Deep Rose Pink, White edged lilac, Salmon, Salmon-pink, Rose, Mauve with violet center, White with brown enter, Creamy White, Garnet Red, Magenta, Mauve-rose, Purple-rose, and Light Purple. Complete Special Mixture of Vilmorin's Holly hocks, 5 cts.

DIANTHUS cruentu s, 1ft. rich deep scarlet; showy in beds.

Hybridus, Crimson Bedder, 1ft. crimson-scarlet; free-bloom Neglectus, 6in. fiery red; fine for pots, edgings, rock garden.

DICTAYNUS fraxinella, 2ft. a splendid lasting perennial;

"Flame Flower"; Flowers in fine panicles; Rose and White. Note. Dictamnus, sometimes called "Dittany" or "Gas Plant", is
of easy culture, thriving best in somewhat dry garden soil. The of easy culture, thriving best in somewhat dr
leaves emit a strong lemon odor when crushed.

leaves emit a strong lemon odor when crushed.
DIPSACUS laciniatus, $8 \mathrm{ft}$, rosy globular heads; decorative.

DRACOCEPHALUM Ruyschianum, 1ft. dark blue, for borders. Virsinianum, Physostegia, large-fl'r'd; Rosy-lilac, also White in terminal racemes; beautiful peren'l to cut, or for the border; sep. or mixed. We offer only the new grandiflora kinds. Giganteum, 4ft, large-fl'rd, crimson; a ha ndsome variety. Complete Special Mixture of Physostegia, 5 cts.

ECHINOPS exaltatus, $7 \mathrm{ft}$. pinnate foliage; showy azure heads. Ritro, 5ft. violet-blue flowers; a fine, showy everlasting.

Sphærocephalus, 6ft. light blue in sphærical heads,

Complete Special Mixture of above kinds, 5 cts.

EPILOBIUM angustifolium, 3ft. showy crimson fl'rs in big long erect racemes; hardy, hands ome, easily-grown, lasting.

EREMURUS $4 \mathrm{ft}$, small, lily-like fl'rs crowded on strong stems, Bungei. yellow; Hinalaicus white; Robustus, pink; these appear like giant hyacinths, aristocratic; separ ate or mixed. ERIGERON Coulteri 2ft. white daisy-lıke, early fl'rs, showy in beds and fine for cutting. A good plant for the rockery. Speciosus grandiflorus, rosy lilac and blue flowers; splendid. ERYNGIUM giganteum, ift.fine heads of blue fl'rs; ornamentai, ERYSIMUM pulchellum, $1 \mathrm{ft}$. yellow, dense, very floriferous. EUPATORIUM Fraseri, 2 ft. fine white clusters, for cutting. EUPHORBIA polychroma, $1 \mathrm{ft}$. forms clumps tipped golden. FOENICULUM vulgare, $4 \mathrm{ft}$. sweet feathery fol, white umbels. FRAGARIA Indica, trails; yellow flowers, red fruits; carpets shaded oil where other things die, and is fine for baskets. FUNKI A coerulea, Day Lily, lovely nodding blue bells; Spring. GALEGA, Goat's Rne, 4ft, pretty azure fl'rs in showy racemes. GENTIANA acaulis, 4in. big blue bells with gold spots; edging. GERANIUM sanguineum, $1 \mathrm{ft}$. lovely lilac clusters all summer. Pratense, 2ft. large, blue fl'rs in corymbs; good for borders. OEUM, Mrs. Bradshaw, 2ft. large, glowing red, d'ble fl'rs; îne. Lady Stratheden, golden yellow, large, d'ble; very handsome. Atrosang nineun, vivid leep scarlet, d'ble; attractive borders. GLOBULARIA tricosantha, 2ft. azure, hairy Globe-fl'r; sum'r. GNAPHALIUM, 6in, Elelweis, the beautiful Swiss Everlast'g. GYPSO?HILA paniculata, $3 \mathrm{ft}$. white clusters; for bouquets. Double, showy in beds, fine to cut; half the plants come true Compacta, 18in. semi-dwarf, dense plants, free-bl'm'g; fine. Not?. Gypsophilas are light, graceful, hardy plants with charming little flowers on fairy ste $\mathrm{n} 3$ that are fine to work up in bouquets or desizis. Once started, a bed of them will last for years.

HEDYSARUM coronarium, 2ft, an elegant, hardy perennial fl'rs in dense racemes; easily grown; Deep Red, White, Mxd. H CLENIUM aut, superbum, $2 \mathrm{ft}$. golden, fine in beds and to cut. Hoopsei, golden yellow, brown disc; free-blooming; splendid. HELIANTHEMUM mutabile, $1 \mathrm{ft}$. Sun Rose, fine colors mixed. HELIANTHUS, Perennial Sunflower, $4 \mathrm{ft}$. showy golden fl'rs. HELIOPSIS Pitcheriana, 4ft. golden; a showy tenacious plant. Soleil d'0r, golden, profuse, showy, fine to cut.

HELLEBORUS Niger, 1ft. Christmas Rose, large, early, Spring. Hybridus, splendid hybrids in many fine colors, mixed. HEMERO CALLIS Middendorfii, 2ft. golden Day Lily; showy. HERACLEUM mantegazzianum, $8 \mathrm{ft}$. big white umbels; fine. Wilhelmsii, 9ft. enormous white umbels; fine back-ground.
HESPERIS, Sweet Rncket, 3ft. big plilox-like trusses of deliciously scented flowers; Purple, Wlite; sep. or mixed. Nana, semi-dwarf, 2ft. large white trusses of bloom.

Tristis, 1ft. brown, not howy but very fragrant.

Complete Mixture of all varieties, 5 cts.

HEUCHERA, Benary's Hybrids, 2ft. white and scarlet, mixed. HIBISCUS speciosus, $5 \mathrm{ft}$. bright scarlet.

Mutabilis, 13ft. flower white passing to rose, 4in. across. Moscheutus, $2 \mathrm{ft}$. rose, lovely semi-bog plant.

Mallow Marvels, 4ft. Iriany fine colors mixed.

Fine Special Mixture of the above Hibiscus, 5 cts.

HIERACIUM aurantiacum, $1 \mathrm{ft}$. orange-red; showy.

HYACINTHUS candicans, $1 \mathrm{ft}$. white bells; very attractive. HYPERICUM elegans, $3 \mathrm{ft}$. rellow; fine hardy perennial.

IBERIS Gibraltarica, 1ft. lilac fl'rs in showy coryubs; sprirg. Semperflorens, $1 \mathrm{ft}$. large, white, sweet fi'rs; ever-bloomirg. Sempervirens, Evergreen Candy tuft, 1ft. pure white in long racemes; nlants branch; one of our best perennials.

Iberis, Perennial Candytuft, in splendid mixture, 5 cts.

INULA gIandulosa, $2 \mathrm{ft}$. each stem tipped with a yellow $110 \mathrm{~cm}$. MacrocephaIa, 4 ft. lemon yellow with golden disc.

Royleana, 2ft. large, golden yellow heads like small sun-fl'rs. IRIS germanica, 2ft. large, silky, many rich colors, mixed.

Kaempfera, 2ft. Japan Iris, huge, open flowers in rich colors; the finest of Iris, mixed; sub-aquatic; excellent for cutting. Siberica superba, $2 \mathrm{ft}$. showy blue and white flowers, mixed. Pumila hybrida, 6in. lovely, big purple and white blooms. Complete Special Mixture of all Iris, 5cts.

ISATIS glauca, 3ft. graceful plant with showy jellow bloom.

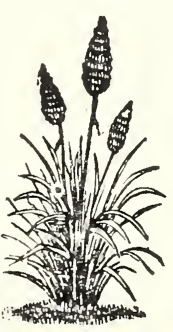

foliage grayish-green, and the flowers are borne in great profusion.

KNIPHOFIA, (Tritoma), 3ft. Flame Flower. a genus of showy garden plants of the Lily Family. Flowers in dense spikes at the summit of strong scapes, See engraving.

Express, blooms first year; buds red, fl'rs yellow; a fine early-blooming variety. Uvaria grandiflora, large, coral-red fl'rs fading to orange: one of the most effective. Mirabilis, early-blooming; flowers varying from bright lemon to golden yellow, and from bright orange to orange-scarlet.

Kniphofia Plant Complete Mixture of Kniphofias, 5 ets.

LATHYRUS latifolius, 8ft. Perenrial Pea Vine, large, showy flowers, white to dark red, several to a stem; ever-blooming; a grand perennial. Colors: Red, Improved White or Pearl, Albus, Roseus, Splendens dark red, Pink Beauty; sep.or mx. Rotundifolius, a fine perennial; see page 21.

LEUCANTHEMUM maximum, splendid perennials with large, white daisy-like flowers on long stems. Showy in beds and fine for cutting. The following are the finest new kinds:

Etoile d'Anvers, 3ft. free-blooming, fl'rs large and attractive. Hybridum, 2ft. the new spring-blooming Marguerite.

King Edward VI, 3ft. robust, with large white flowers.

Mrs. C. Lowthian Bell, 3ft. a new and splendid variety.

Shasta Daisy, Alaska, white; California, yellow: sep. or mixt, The Speaker. $3 \mathrm{ft}$. v॰ry large plants and showy flowers. Uliginosum, $3 \mathrm{ft}$. Ox-eye daisy; white and very floriferous. LIGULARIA macrophylIa, 4ft. yellow flowers in long, dense, spikes; a large plant for sub-tropical gardening. 


\section{Huge in size}

Show

Rarest of Perennials

For many years I have been trying to obtain seeds of Perry's New White Orientam glad to say, 1 have ootained from the grower a limited quantity, and ofr them at 5 cents a packet of 40 to 50 eds. If you want something rare and beautiful be sure to get a packet of tacese Oriental Poppies. They

yo or friends

Geo, W. Park.
PERRY'S RARE WHITE POPPY al Poppy, but without success. This year,

PAPAVER ORIENTALISS, Glorious Hybrids

Complete Special Mixture including Perry's New White Poppy, 5 cts.

MONG THE most attractive of all terennials are the Oriental Poppies. The fiowers are larger and n.cre showy than Darwin 'I ulups, show many rich colors from white to intense crimson as well as salnuon and orange shades. Once started, a bed of them will last for years, and never fail to display their big brilliant waving flowers every summer. The foliage is almost as handsome as the coarser Ferns, ard the many flower stems are strong, and hold their showy flowers three feet above the graceful foliage. The plants are easily started flom seeds, and our seeds were saved by a skillful English florist. The rare varieties in rosy salmon and white are included in our special mixture. Be sure to add this glorious perennial to your order.

Bracteatum, 3ft. glowing red, very large and showy.

Brilliant, 3 ft. vivid fiery red, very attractive.

Col ssseum, $4 \mathrm{ft}$. giant enormous flower, dazzling scarlet.

Aprisot Queen, 3 it. salmon or apricot color, charming.

Remoraadt, $3 \mathrm{ft}$, magnificent orange-scarlet, showy.

Princes Victo ia Louise, $3 \mathrm{ft}$. magnificent salmon-pink.

LIA TRIS s picata 2ft. Blazinr Star, purple fl'rs on long spikes. LIN.ARIA nacedonica speciosa, 3ft. large, snapdragon-like gol len do wers in long spikes; sown early it blooms first year. Cymballaria, trailing; small pretty foliage and flowers; fine to cover a bed in sur or shade. a splendid basket or bracket-pot plant. Colors: Lilac, White; separate or mixed.

Cymb. globosa little globe-like plants covered with bloom; ine for pots and edgings, thrives in sun or shade; new.

LINDELOPHIA spectabilis $2 \mathrm{ft}$. pretty blue fi'rs in terminal racem 3 , a handso.ne Boragewort 01 easy culture.

LINU 1, Perennial Flax Flavum, bell-like transparent, golden fl'rs in branched heads. A very handsome Flax.

Lewisii, very besutiful corn-flower blue in racemes.

Narbonense, rich blue fl'rs in panicles plant erect; showy.

Perenne, a mass of lovely fl'rs each day BIue White, Mixed. Co nplete Mixture of Perennial Flax, 5 cts.

LUNARIA biennis, Honesty, 2ft. very pretty fl'rs in panicles; phlox-like, appearing in spring; fl'rs succeeded by charming silvery seed vessels. We have all the varieties: Purple, White Crimson, and Variegated-leaved; sep. or mixed, 5cts. Lunaria will bloom the first year if sown early.

LOBELIA cardinalis, $2 \mathrm{ft}$. the beautiful, native cardınal flower, one ol our loveliest perennials; bright scarlet spikes; likes moist soil and partial shade; blooms throughout autumn.

Syphilitica, 2ft bushy; spikes of lovely blue flowers; likes moisture; blooms throughout autumn.

LUPINUS. The perennial Lupins are among the most showy and beautiful of perennials. The plants are tall, branch freely, and each branch shows a long spike of attractive flowers. The new hybrids are exceptionally handsome, and $a$ bed of them should be in every garden. We offer

Arboreus Aureus, $5 \mathrm{ft}$. yellow; also White, sep. or mixed. Golden Spire, $5 \mathrm{ft}$. new, long spikes; fl'rs rich golden yellow with purple; on of the most gorgeous and beautiful.

Douglasi superbus, violet-blue with white, fine spikes.

Excelsior, Now Hybrids $3 \mathrm{ft}$. splendid, fine mixed colors.

Ielway'. New Hybrids 3ft. magnificent; splendid colors.

-liott's Sweet-scented Hybrids, finest colors in mfxture.

Polyphyllus varieties in special superb mixture, 5 cts.

Complete Special Mixture of all perennial Lupins, 5 cts.

LCHNIS ebalcedonica, $3 \mathrm{ft}$. a beautiful perennial, blooming

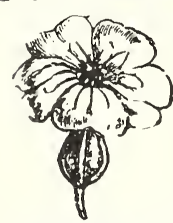
first season; deserves a place in every garden; flowers in heads like Sweet Wm., freeblooming, long-blooming, showy; rich scarlet; splendid for beds or groups in border. Arckwrightii, 18in. new, elegant hybrids in rich red colors; very fine in groups.

Haagean?, 1ft. large fl'rs; fine bright colors. Viscaria splendens, $1 \mathrm{ft}$. German Catchfly, fine for beds; brilliant red, very showy; Coehnis Flower blooms in May and June; easily grown. Complete Special Mixture of the above kinds of Lychnis, 5 c. LPTHRUM roseum superbum, $3 \mathrm{ft}$. long spikes of rosy bloom. Salicaria, $3 \mathrm{ft}$. rich purple spikes; likes moist soil; fine.

MALVA AIcea, $5 \mathrm{ft}$. a rare, handsome perennial, much like $\mathbf{M}$. Moschata, but with large A'rs; pretty rosy-purple color.
Mrs. Perry, 3 it. orange-apricot, rare and handsome.

Queen Alexandra $3 \mathrm{ft}$. rosy-salmon with crimson spots Royal Scarlet. $3 \mathrm{ft}$ gigantic scarlet fowers

Benary's Finost German Mixed Hybrids, 5 cts.

Excelsior English Hybrids. new from a choice collection.

Complete special mixture 0 fines English and German, $5 c$.
M. Moschata, 2ft. branches and becomes a mass of large cup-shaped flowers. Colors Pink, White, sep. or mixed, 5c.

MIMULUS cardinalis, 2ft. large gaping fl's, long stems, show cardina' scarlet fi'rs born freeiy the first season.

MARSH marigold, (Caltha Palustris), 6in a fine semi-aquatic plants b come globular mass or golden bloom in early spring.

MECONOPSIS cambrica, 1ft. Welsh Poppy, a vcry showy and des.rable peren'l for rock-work; large sulr hur fl'rs.

MENYAN1 HES trifoliata, trails, Bog Bean, fl'rs purplish.

MONARDA hybrida. $8 \mathrm{ft}$. beautiful, easily grown, free blooming plants; big heads of many hued flowers; splendid.

MORINA longifolia, $3 \mathrm{ft}$ pretty foliage; fl'rs fink tuces changing to lovely crimson, in whorls along leafy stems; shor y.

MYOSOTIS palustris semperilorens, $1 \mathrm{ft}$. the charming Marsh Forget-me-not; fine big blu clusters all season.

OENOTHERA Fraseri, 2 ft. large, golden yellow; floriferous.

Odorata, 2ft. large, yellow changing to red, sweet-scented; biennial, blooming freely in early spring.

OMPHALODES linifolia, $1 \mathrm{ft}$. a pretty biennial; fine racemes of white fl'rs. Sown in spring, it blooms in aumn.

ONOPORDON acanthium, $5 \mathrm{ft}$. Cotton Thistle, a bold, handsome plant with woolly branches, silvery foliage and purple fi'rs. Tauricum, $7 \mathrm{ft}$. purple heads of bloom, foliage white, woolly. OROBUS niger, 3ft. Pea-like fl'r, purple on many-fir'd stems. PAEONY, Chinese, finest d'ble from Prize collections, mixed. Officinalis, single, deep dark red, splendid.

PAPAVER pilosum, $2 \mathrm{ft}$. a showy perennial, bearing in summer large orange flowers, several on one stem, marked with a white spot at the base of each petal. Leaves serrated and both sides covered with white hairs.

PENTSTEMONS. On page 16 we offer the Gloxinia-flower'd hybrids of $\mathbf{P}$. Hartwegii, which bloom the first season, and are fine for bedding. On this page we offer the following beautiful kinds: Cobea, 18 inches, flowers white shaded purple, large and beautiful.

Gordoni splendens, 3 ft. The Gloxinia-flowered Pentstemon dark blue flowers on long erect spikes.

Hybridus graciella, $2 \mathrm{ft}$, small flowers in abundance; varied and handsome colors; one of the best peren'l Pentstemors. Pulchellus hybridus, 2 it. fis. bell-like in graceful spiles; colors pink purple, violet in many shades; excellent.

Southgate Gem, $18 \mathrm{in}$. a splendid bedding plant. When in Ireland we saw glorious borders of this crimson-scarlet Pentstemon in Phoeniz Park, Dublin, and can vouch for its great beauty. We urge our friends to try it. 5c.

Complete special mixture of all our fine Pentstemons, 5c.

PHLOX, Perennial, KELWAY's New Hybrids, 5 cts.

Note. We highly recommend Kelway's Improved Strain of Perennial Phlox. The flowers are large, of many splendid colors, borne in big panicles. These are splendid, showy perennials; fine for beds or borders. Plants increase into big clumps, and are from two to three feet high, blooming throughout the autumn. This Phlox is perfectly hardy and makes a magnificent display.

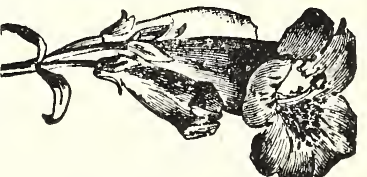




\section{PRIMULA, Beautiful Hardy Kinds}

\section{Complete special mixture of hardy Primulas, 5 cts.}

T HE hardy Primroses are splendid perennials, mostly bloonmig early in spring. The flowers are clustered, are charming in texture, varied and rich in color, and always make a fine display in the garden. They deserve to be better known. The plants are easily raised from seeds, but these are often tardy in germ-
ination, even when sown as soon as ripe. We urge our patrons to try hardy Primroses. They will afford a lot of pleasure, and be the talk of the neighborhood. Acaulis, grandiflora, 6 in. Blue, White, Mixed. Auricula, 6 in. finest strain from prize flowers. Denticulata granditfora, $1 \mathrm{ft}$. white and blue. Beesiana, $1 \mathrm{ft}$. glowing velvety purple with gold eye. B riscoei, $1 \mathrm{ft}$. a rare Primula. Bullesiana hybrida, $1 \mathrm{ft}$. fine colors. Bulleyana, 2 ft. bright chrome yellow. Cortusoides, $1 \mathrm{ft}$. charming rose flowers.

Parinosa, 6 in. purple with gold eye.

Frondosa, 1 ft. rosy lilac, yiolet center.

Ipswich hybrids, $1 \mathrm{ft}$. charming shades of pink rose, or ange, purple, mauve.

Japonica, 2 ft. superb; mixed colors; moist shade.

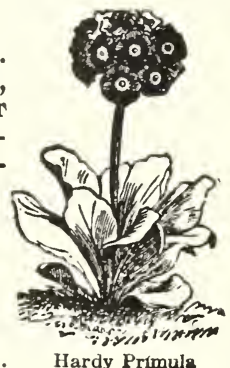

Officinalis hybridus, $1 \mathrm{ft}$. sweet, mixed. Pulverulenta, $2 \mathrm{ft}$. shining red flowers. Rosea grandiflora, $1 \mathrm{ft}$. charming rose. Sieboldii, 1 ft. large-flow'd, finest mixed.

Sikkimensis, $1 \mathrm{ft}$. yellow, fragrant.

Veris Aurea, golden yellow umbels. Veris, $1 \mathrm{ft}$, attractive, fragrant, mixed. Complete mixture of Veris Primroses. Grandiflora, giant-flow'd showy, mixed. Verticillata, $1 \mathrm{ft}$. golden yellow.

Gold-laced, brovn, edged gold, sliowy. Vulgaris. 6 inch, true yellow; very fine.

\section{PHYTOLACCA decandra, 6ft. Pokeberry, a showy native plant.}

Kaempferi, $4 \mathrm{ft}$. large leaves, black berries; oanamental.

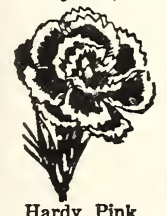

\section{PINKS, Mardy Garden}

\section{Complete Special Mixture, 5 cts.}

These Pinks have been greatly improved being plain and fringed, single and double, rich-colored and variegated, summer-blooming. We have the finest kinds as follows: Plumarius diadematus, single, spotted, sw eet-scented. Diadematus double, mixed. Hardy Pink Pheasant Eye, fringcd, richly scented. Double and semi-double, $1 \mathrm{ft}$. fine colors in mixture. Dwarf Erfurt Pheasant Eye. dwarf double, mixed. Perpetual Pheasant Eye, finest single mixed.

Double White with distinct eye; a fine new variety. Double Perpetual Red in splendid glowing shades.

Double French Perpetual Cyclops, large, beautiful colors. Scoticus t, pl, splendid French double in fine mirture.

Complete Special Mixture of all the above Hardy Pinks, 5c, POLEMONIUM, Jacob's Ladder, 2ft. blue, large-fl'wd, fine.

Flore albo, spikes of lovely white flowers.

Richardsonii, $1 \mathrm{ft}$, early-flowering, blue, new, handsome.

POLYGONUM Baldschuanicum, robust vine, 20ft. rose clust ers, free-blooming all summer, rare and beautiful.

Multiflorum, 20ft. rapid and free-blooming climber.

Sachalinense, 8ft. strong-growing, hardy peren'l; greenishyellow fl'rs and ornamental foliage, useful for forage.

Sieboldii, 6ft. pretty foliage and white flowers in profusion.

POTENTILLA hybrida, mostly low-growing plants with pretty fl'rs in mixed shades of yellow, rose, brown and scarlet. Double-fIowered, like the preceding, but double flowers.

PRUNELLA grandiflora, 6in. large-flow'd, blue; for rockery. PUERARIA Thunbergiana, $40 \mathrm{ft}$. Kudzu vine; blue clusters.

PYRETHRUM roseum, $2 \mathrm{ft}$. beautiful cosmos-like fls. in many colors on strong stems; fine for cutting.

Kelway's Exhibition and Border strain, 5 cts.

Double-fl. Kelway's Exhibition and Border strain; fine. Note. There are no finer Pyrethrums, single or double, than Kelway's. Our seeds are direct from him, and are the product of his big beds of finest named varieties. Only 5 cents a package.

PYRETHRUM cinerarifolium, 2 ft. lovely white daisy-like flowers in abundance; fine for cutting.

Tchihatchewii, $2 \mathrm{ft}$. white fls. gold disc; a handsome species forming dense tufts; thrives on dry banks and under trees where grass will not grow. Start in a box and transplant. RHEUM collinianum, $7 \mathrm{ft}$. gigantic leaves, very ornamental. Emodi, $5 \mathrm{ft}$. enormous dark leaves; very attractive.

Monarch, $4 \mathrm{ft}$. rhubarb, big leaves on huge long stems,

Undulatum giganteum, $5 \mathrm{ft}$. huge leaves; a fine variety.

Palmatum tanguticum fi. rubro, $7 \mathrm{ft}$. palmate leaves

large panicles of brilliant dark red flowers; splendid.

RUDBECKIA Newmanii, 2ft. golden yellow, very floriferous.

Purpurea hybrids, $4 \mathrm{ft}$. lovely large flowers in red shades. SALVIA argentea, $4 \mathrm{ft}$. large ornamental white leaves.

Globosa, 4 ft. silvery; plant smothered with white flowers Salvia turkestanica. $5 \mathrm{ft}$. bright pink flowers, silvery foliage. Ringens, $2 \mathrm{ft}$. sage-like leaves, large reddish nurple flowers. SAPONARIA officinalis fl. pl. 2 ft. heads of soft pink fl'rs. SAXIFRAGA, 1ft. low perennials for edgings. mixed colors.
SCABIOSA Caucasica, 3 ft. lavender, fringed, fine to cut. Alba, white flowers; Perfecta lavender, a desirable variety. Japonica, 2 ft. a splendid sort for beds or cutting; easily grown, floriferous and beautiful; superb lavender blue flw. SEDUM, $1 \mathrm{ft}$, succulent for edgings and borders; fine mixed. SENECIO clivorum, $3 \mathrm{ft}$, rich oran ${ }^{\prime}$ e; big decorative $f \in \mathrm{I}^{\prime} \mathrm{n}^{\prime} l$, SIDALCEA, Rosy Gem, 2 ft, spikes of lovely flws like a snall hollyhock; awarded prize by Royal Hort, Society of England SILENE asterias grandiflora, $2 \mathrm{ft}$. large scarlet $\mathrm{is}$; rare. Fortune1, $2 \mathrm{ft}$, bright rose, with feathered petals; fine. Orientalis compacta, 2 it, dark rose fl'rs, in dense corynts, Schafta, 8 in, very showy trailing peren'l, rosy purple,

SMILACINA racemosa, $2 \mathrm{ft}$, false Solomon's seal; graceful. STACHYS Lanata, $2 \mathrm{ft}$. woolly stem and leaves, dark rose fis. SPIREA filipendula, 3 ft. dropwort; rosy white; tuberous. STENACTIS speciosa, $2 \mathrm{ft}$, lovely blue, profuse, good to cut. STOKESIA cyanea, $1 \mathrm{ft}$, Stokes Aster, keautiful, fine to cut. SWEET Wm, Dianthus Barbatus, 1ft, Single: White, Dask Crimson, Harlequin, Red, Rose, Pink Beauty, Scarlet Beauty, Holborn Glory, Margined, Giant Auricula-eyed; sep. or mixed, Double: White ( rimson, Margined, Rose, Black-red, sep, or mlxed, New Annual. mixed, Dwarf Compact, mixed,

SYMPHYTUM asperrimum, $4 \mathrm{ft}$, prickly comfrey, rosy lilac, TELEKIA speciosa, $4 \mathrm{ft}$, showy and ornmnt'l, golden bloom. THALICTRUM aquilegifolium, $3 \mathrm{ft}$. lovely foliage; ros $y$ fls. Dipterocarpum, $3 \mathrm{ft}$, lilac-rose; charming for cutting.

$\star$ THERMOPSIS Carolinianum, $4 \mathrm{ft}$, very beautiful new perennial; long spikes of golden lupin-like fis; very showy, TIGRIDIA canariensis, $1 \mathrm{ft}$, yellow, shell-like, spotted,

TRIFOLIUM repens fol, atropurpureis, 6 in, white fls, crim son foliage, fine bee pasture; sometimes called shamrock; Rubens, $1 \mathrm{ft}$, carmine, egg-shaped heads 2 inches long. TROLLIUS europeus, $2 \mathrm{ft}$ globe flower; compact, floriferous, VERBASCUM, Harkness Hybrids $7 \mathrm{ft}$, huge sulphur spikes, Miss Willmott, $5 \mathrm{ft}$ jellowish white, in fine large spikes, Olympicum, 6ft. golden fls; Pannosum, $5 \mathrm{ft}$. sulphur yellow.

Phoenicenm hybrids, $3 \mathrm{ft}$. various colors, white to purple, mix

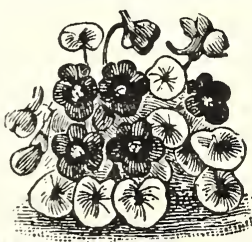

Plant of Vlola Odorata VIOLA odorata, 4 inch, the swee. English violet; blooms almost con tinuously, ranging in color from white to dark blue, large, long. stemmed and deliciously fragrant. Queen Charlotte. large dark blue; fine for pots or garden.

The Czar, lovely blue, an old familiar sort, but one of the best. The Czar, fine white, very desirable Complete mix. choice Eng. violets.

VERONICA spicats, $2 \mathrm{ft}$. lovely shades of blue, pretty.

Longifolia, 2ft. compact clusters of blue fis; loug leaves; fin WAHLENBERGIA grand. 2ft. Blue, also White large-fl'wd. Duplex, double. very flne; White, Blue, sep. or mixed, Mariesii, dwarf, 1ft. large fls; White. Blue, sep. or mixed. Complete Special Mixturc of the ubove Wahlenbergias, $5 \mathrm{c}$ WALLFLOWER, 2ft, Whitc, Crimson, Yellow, Bloo. Lic and Brown; finest named single yari ties; sep. or mix d. Double Dwarf, branching, Honary's splendid mixed. YUCCA Aloifolia, Adam's N -Jle; $\Lambda$. fol. variegatis; A, Quat ricolor; Filamentosa, silk grass; Whipplei; sep or mixed. 


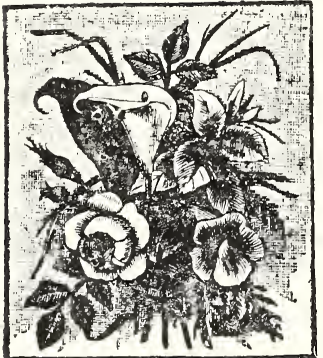

\section{CHOICE SEEDS for the WINDOW GARDEN}

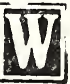
necessary to tell you that there is much pleasure as well as economy in growing your window plants from seeds. To watch and tend the little seedlings until they become blooming plants is always interesting, and they are more appreciated because of the personal care given them. So we urge our friends to sow liberally of these seeds in pots or protected beds. We especially recommend our seeds of Calceolaria, Cineraria, Carnation, Cyclamen, Geranium, Heliotrope, Lantana, Primrose, Solanum, Stock, Thunbergia, Verbena and Wallflower. These all do well in pots and bloom abundantly in a sunny window in summer or winter. All are easily raised from the dependable seeds we supply. We feel sure you will be delighted with the results obtained from our Window Garden seeds. Cnly 5 cts. a pkt.

ABRUS praecatorius, $15 \mathrm{ft}$. Vine, Prayer Bean, as the seeds aro used to make rosaries, being shining scarlet, very pretty; lovelv foliage and handsome clusters of purple th; also calle 1 weather plant, because its leaves indicate the fut're condition of the weather.

A 3'JTILON, Benary's Giant, 4ft. huge, bell shaped fls in fine shades. Seedlings bloom within 6 months.

Hibiscus-flowered, large hibiscus-like fls of various shades; fine for pots; a splendid variety.

New Hybrids, from a fine collection of the best varieties.

Complete special mixture of all the a ove Abutilons, 5 cts.

Note. The Abutilons are elegant window-garden shrubs bearing graceful, bell-shaped, red, yellow and white fls. They grow $4 \mathrm{ft}$. high, ACACIA Arabica, 18ft. the souree of Gum Arabia

Dealbata, $5 \mathrm{ft}$. Silver Wattle, fine foliage.

Decurrens, 5ft. Black Wattle, very floriferous.

Farnesiana, 8ft. blooms in early spring; yellow.

Julibrissin, 10ft. a hardy species of Albizzia.

Longifolia, 10ft. long-leaf Golden Wattle, golden flowers.

Lophanta speciosa, $5 \mathrm{ft}$. an elegant pot plant.

Complete special mixture of Acacias, 5 cts.

AGAPANTHUS Umbellatus, $2 \mathrm{ft}$. an elegant large pot plant; bears fine blue bells in big clusters: likes partial shade; showy.

A GATHEA amelloides, $1 \mathrm{ft}$. Paris Daisv, blue; for winter bloom.

AVTIGONON leptopus, vine, $30 \mathrm{ft}$. a splendid tuberous Southern vine, hardy with rotection north; fls rosy-carmine in big clusters, blooming all season.

ARISTOLOCHIA elegans, $8 \mathrm{ft}$. a lovely vine, beautiful in both foliare and fls and easy to grow.

ASCLEPIAS curassavica, 2ft, fis red and gold; ever-blooming.

ASPARAGUS plumosis nanus, $2 \mathrm{ft}$. a dwarf variety; fine for pots.

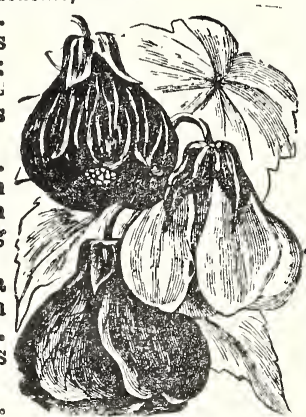

Graceful Abutilon blooms Plumosis robustus, $10 \mathrm{ft}$. a window vine of great beauty. Tenuissimus, $5 \mathrm{ft}$. a rare and very beautiful pot plant. Spinosus, 30ft. valuable for pillars and cut foliage.

Sprengeri, 6ft. Emerald Feather, a handsome window plant.

Verticillatus, $15 \mathrm{ft}$, a pretty sort for out-door culture.

Special mixture of Asparagus, 5 cts.

BEG0NIA gracilis, everplooming, 1ft. excellent for winterblooming in the window; graceful, profuse-bloo mer; mixed Luminosa, $1 \mathrm{ft}$. bronze foliage, fiery scarlec fls; for beds, pots Guire de Louveciennes, $1 \mathrm{ft}$. white flushea vose; floriferous, late- and long-blooming: splendid for pot plant,

Semperflorens Bedding Queen, 1ft. giant-1, looming, pink. Cosapacta atropurpurea, 6in. purplish-carmine; fine bedder. Flame of Love, $1 \mathrm{ft}$. large, rich scarlet fls; green foliage. Triumph, 1ft. lovely, large white fls, slightly flushed pink. Vernon, 1ft. blood-red fls, bronze foliage; fine for beds.

Eifordia grand. superba, 1 ft. charming light rose; splendid. Resea, 1ft. charming rose, floriferous; good for beds.

Complete special mixture of Gracilis and Semperflorens. Rex, tnest, of Begonias, from Benary's rich collection, 5 cts. Note. All of the Fibrous-rooted Begonias we offer are especially handsome in plant and flower, and all are practically ever-blooming All are easily grown from seeds, and the Gracilis varieties are particcome with the seeds. Tuberous-rooted Begonias bloom in summer and our seeds are the best obtainable, coming from Begonia specialists. Plants of both classes begin to bloom in autumn from spring sowing.
BEGONIA, TUBEROUS-ROOTED

We have the best quality of Tuberous Begonia seeds that can be obtained. Kelway's of England matie a specialty of these Begonias, and pride themaelves in their collection Their "Perfect Model" in both Single and Double, cannot be excelled, and their seeds are new and carefully saved. We cannot too highly recommend them.

Kelway's Perfect Model, Single, largest fls; best colors mixt. Kelway's Perfect Model, Double, largest fis; best colors mixt. Chrysantha, Sirgle, yellow, lovely salmon-rose center.

Special mixture of Single and Double tukerous-rooted, 5 cts, Calceolaria, Kelway's Perfect Medel, without exception the fin est strain of Large-flowered Calceolarias in existence. The piants are of perfect habit, neither too tall nor too dwarf; the big flowers are well-rounded, of the most excellent colors and mark. ings, and come in huge clusters. You'll marvel at the surpassing beauty of these glorious pot plants.

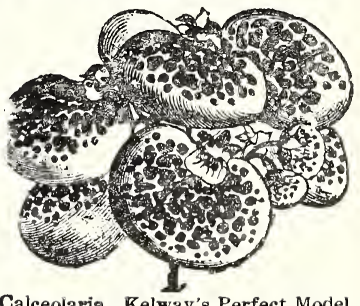
A window-full in bloom Calceolaria. Kelway's Perfect Model will be a source of untold pleasure. Easily grown. Cultural directions come with the seeds. Finest mixture. 5 cts. Also Grandiflora Tigrina, $1 \mathrm{ft}$. most beautiful, from Benary; mixed. Pumila compacta, Benary's Dwarf, tigred and seffs.

Olymp.a, golden yellow, blotched brown; very showy.

Striata, new, striped; rare and beauttful.

Clibrani, Profusa 2ft. small canary fls; very free-blooming Complete special mixture of Calceolarias. 5 cts.

CAMELLIA Japonica, double, Japanese Rose, charming shrub. CENTROSE MA grandiflora, 6ft. pea-like vine, violet flowers. Cineraroia Grandislora. The most showy and beautiful of window plants; nothing in a plant window is so attractive, the flowers being large, exceedingly bright in col-

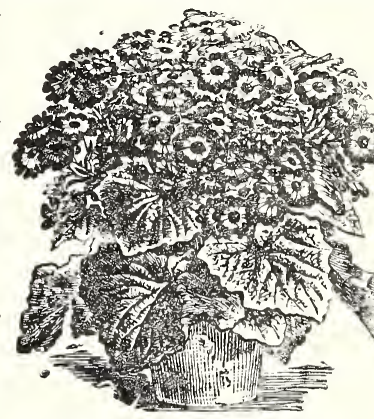

Cineraria, Kelway's Perîcet Miodel or, and produced i’r elegant clusters.as indicated in the engraving.

Kelway's Perfect Modol, the finest of all Cinerarias: iust right in form for poticulture, and bearing in huge clusters, glorious flowers in size, color and strikıng variegations. Surpesses all other window plants in rich displav. Tasily grown: fine mixed Kelway's Pure White also Kelway's Sky Blue.

Kelway's grand. Cineraria, Double, Perfect Moàel, mixed.

Stella, Kelway's Choicest Dwarf, fts cactus-shaped. and many showing a distinct white edge or canrer: a îne onว,

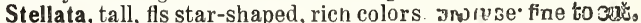

French Cinerarias. Vilmorins of Paris have aeveloped ai cos. traordinary strain of Cinerarias, and we are preased to jofos Royal Blue, Antique Rose Striped. White, Glowing Scarlet, Crimoson NOTE. Cinerarias are easily grown. The seeds start quic $157 \% 2020$ NoTE. Cinerarias are easily grown. The seeds start quicks the plants thrive in any good soil. It is necessary to sprinkle tivgly car 


\section{CYCLAMEN Persicum Giganteum}

Finest Known Strain, direct from France. Complete Special Mixture, 5 cts.

HE little engraving snows a plant of the beautiful, easily-grown CYCLAMEN Persicum, and I offer seeds of the finest known strain, grown by a French specialist. Seedling plants appear in a month after the seeds are sown, and begin to bloom in from 15 to 18 months, keeping up the display all winter. As a rule every seed will produce a fine plant, and a windowful of the different colors is a glorious sight. The leaves are of ten as beautifully blotched and veined as a choice foliage plant. I have all the fine colors, and offer them either separate or in complete mixture at 5 cts. a pkt. containing 8 seeds. Bright Kose, charming; Pure White, green leaved; White with carmine center; Salmon-rose, new, fine color; Carmine Red, very showy; Brilliant Rose wich splendid red eye; Blood Red, benutiful. Grandiflorum, mixed colors; Papilio, fringed fls. mixed. NOTE. Cyclamen Persicum is the finest of the many species. C. Persicum Giganteum bears
the largest and finest flowers, and has the best marked foliage. Try this plant for your window.

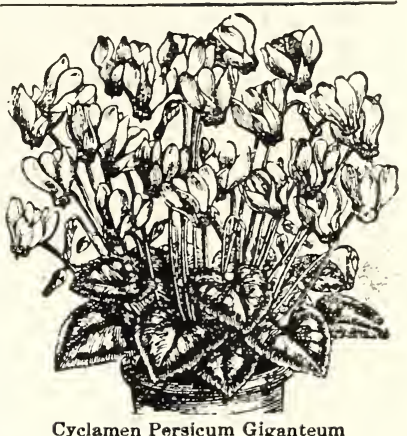
BIGNONIA Tweediana, vine from Buenos Ayres, gold yellow.|GERBER.1 Jamesonii, 2ft. deep scarlet Arrican Laisy. CARNATION, for winter-blooming in pots in the witdow; $1 \mathrm{ft}$. The plants stool out into clumps, and bear an abundance of large, very double, richly scented flowers of the most charming colors. White, Rose, Crimson, Scarlet, Yellow; sep. or mixed. Start the seeds in spring for winter-blooming. Picotee, $1 \mathrm{ft}$. double fragrant fis. with distinct edge.

Perpetual or tree, $1 \mathrm{ft}$. continuous-blooming, double, hardy. CALLA Æthiopica Devoniensis, White Calla, fine house plant. CAPSICUM, (Yepper),excellent pot plants. See page 8. CASSIA floribunda, $2 \mathrm{ft}$. annual, free-blooming, golden yellow. CHEIRANTHUS Kewensis, $2 \mathrm{ft}$. sulphur passing into golden and violet; blooms from Nov. till spring.

CHRYSANTHEMUM, 2ft. C. de Chambord, White Paris Daisy. Indicum fI. pl. double, early-flowering; splendid; fine mixed. Japonicum fl. pI. finest double Japan sorts, mixed. Uliginosum, $6 \mathrm{ft}$. branched, with white flowers in profusion, resembling a hnge hardy Aster plant; handsome. CLIANTHUS puniceus, $5 \mathrm{ft}$. brilliant red with white spots. Dampieri, 2 ft.dark red and black,splendid.

CLITORIA ternatea, $6 \mathrm{ft}$. pretty $\mathrm{Pea}$-like vine; rich blue.

COLEUS; Kelway's Unique, new hybrids with elegant
twisted leaves embossed toward

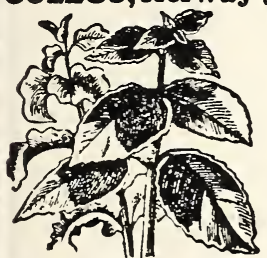

Coleus plant the margin with green and golden yellow upon white ground; fine. Pyrenean Giant, elegant giant sorts in fine mixture; large and fine.

Striped Empel, lacinated leaves striped with green, white, yellow and brown; from Vilmorin.

Benary's Exhibition, extra, the finest of Coleus; saved from Benary's superb collection; great range of colors. Try this splendid strain this season. Benary's Large-leaved, richly variegated, splendid, 5 cts. Complete Special mixture of all the above sorts, $5 \mathrm{cts}$. COMMELINA Sellowiana, 18in. large cobalt-blue fiowers. CONVOLVULUS Mauritanicus, trailer, fine blue, for baskets. Aureus superbus, lorely vine, golden flowers.

CUPHEA platycentra, Cigar Plant, $1 \mathrm{ft}$. fine pot and border plant: free-blooming and ever-blooming: fls. rich scarlet. DASYLIRION Iongifolium, $5 \mathrm{ft}$. a magnificent pot plant. DOLICHOS lignosus, 6ft. A ustralian Pea Vine; purple fis. DRACAENA, pretty sub-tropical pot plants; fine mixed,5cts. EPACRIS hrbrida, $3 \mathrm{ft}$. winter-blooming, fine: best seed mixt. ERIANTHUS Ravennae, $5 \mathrm{ft}$. a handsome hardy grass. ERYTHRINA crista-p,alli, $3 \mathrm{ft}$. scarlet ffowers in racemes. EUCALYPTUS globulus, a beautiful semi-tropical tree. Citriodora, $3 \mathrm{ft}$. very fragrant foliage, fine for pots. Resinifera, Red Gum, extremely hardy, handsome. Fine mixture of many kinds of Eucalyptus, $5 \mathrm{cts}$. EUPATORIUM grandiflorum, 2 ft. large white, winter-bloom. FRANCOA ramosa, 2 ft. Bridal Wreath; elegant white fls. FREESIA hybrida, $1 \mathrm{ft}$. sweet-scented, bloom in 6 mo. mixed. FUCHSIA, fine pot and border plants, Hybrids are best. Boliviana, $1 \mathrm{ft}$, scarlet racemes. Corymbiflora, $2 \mathrm{ft}$. carmine. Coccinea, 2ft. scarlet, hardy. Procumbens, droops; baskets. Hybrida Double, best mixed. Fulgens, 2ft. Goselli, scarlet. Best Single and Double mixt. A bove Fuchsias in complete mixture. 5 cts.

GAZANIA Iongiscapa, 8in. extremely free-blooming annual; fls. 2in. across, lovely golden ye!low with white spotted zone and chocolate ring; of easiest culture.

H ybrida, superb varieties for pots; mixed colors.

GESNERIA hybrila, 2ft. scarlet, etc. mixed: seeds small.

CLOXINIA hybrida, $1 \mathrm{ft}$.fine summer-blooming tuberous

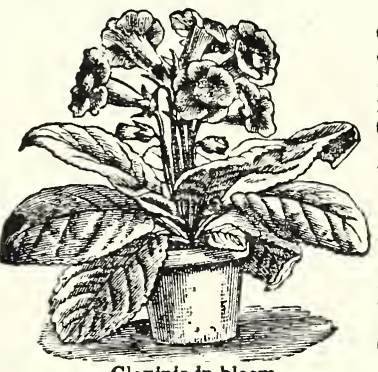

Gloxinia in bloom pot plants; fls. large, richcolored and showy. Wo offer the finest French and German strains, and include cultural notes.

Crassifolia, large-flowe $r$ ed extra fine, mixed.

Valleranda, Spotted, Margined and stained; superb varieties mixed.

Vilmorin's, Splendid Mixture, very superior.

French Hybrida, unsurpassed strain, fine mixt. Gloxinia hybrida in fine Complete Mixture, 5cts. Dear Mr. Park: From the Gloxinia seed packet I got from you, I
raised 85 nice plants, and I wish you could see them now, full of buds, ready to open. I also have Cyclamen and Cineraria plants from ycur
seeds. You'll hear from me next year. Alice E. Dodd, Condersport, $\mathrm{F} \mathrm{a}$. HEDYClliUM Gardnerianum, $4 \mathrm{ft}$. an easily-grown (hardy South) pot plant that likes moisture; fls. lemon and white, very sweet scented and beautiful; is about as hardy as Canna, and requires same treatment.

HELIOTROP 2 , 2 ft. easily-grown; free-blooming plants for pots or beds; fis. small, in big clusters, and deliciously scented: colors range from white to dark royal purple.

White Lady, pure white; Queen Marguerite, Jarge dark blue; Peruviana, light blue; Roi des noirs, large dark violet; Louise Deleaux, giant fl'wd. rose; Triumph de Liege, large, dark lilac; Mme. Bruant, large, dark lilac, super b; sep. or mixed. Cyclope, $1 \mathrm{ft}$. dwarf. rolust, regular growth, with big umbels of large fis. of the prettiest shades, 5 cts.

Lemoine's Giant, Mixed, large fl'wd, and large-clustered. Complete Mixture of all varietias of Heliotrope, $5 \mathrm{cts}$.

HIBISCUS Manihot Sunset, $4 \mathrm{ft}$. splendid; the fls. clustered at the tips of the branches, are 6in. across, yellow with showy dark centers; grown as a pot plant or in the garden. HIBISCUS, shrubby plants with Hollyhock-like fls, See p. 25. IMPATIENS, beautiful everblooming African Balsams; splendid, easily-grown window plants. See page 12.

Holsti, New Hybrids, 2 ft. beautiful pot plants; mixed colors. Sultani, King Albert, 18in. brilliant Tyrian rose.

Balfouri, $2 \mathrm{ft}$. orchid-fiwd; rare and very handsome.

NOTE. Balfouri is one of the most beautiful plants for the window or for a partially shaded bed out-doors. It forms a tree-like plant covered with flowers of exquisite texture, each showing white and rich carmine colors. The seeds are cometimes tardy in starting.

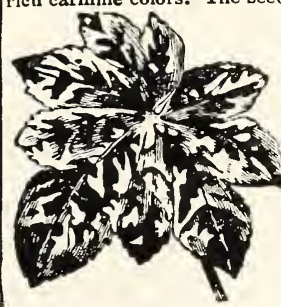

Lavatera Arborea Variegata
JACARANDA mimosifolia, $5 \mathrm{ft}$. ferny foliage. blue clusters.

KALANCHOE Kewensis, $3 \mathrm{ft}$. scarlet; fine to cut.

KENNEDYA comptoniana, vine, blue, very beautiful.

Bimaculata, azure,white spots.

Kennedya in splendid mixture.

LAVATERA arborea variegata, $5 \mathrm{ft}$. an easily grown pot plant. The older the plant the richer the green and yellow variegation. 


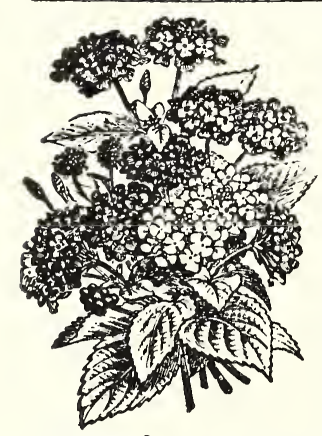

Lantana for pota or beds

\section{LANTANA, Improved Large-flowered}

Complete Special Mixture of all colors, 5 cts.

O NE of the good things for summer-blooming North and South is Lantana, especially in itsimproved varieties. The plants thrive in the hot sun, and bloom abundantly whether the weather is wet or dry. The hower's come in fine clusters, not unlike those of Verbena, and keep up a continuous display throughout the season, the colors being rich and distinct - white and yellow and rose and red in many shades. Each seed contains several germs, and will mostly produce more than one plant. The new Dwarf race is excellent for beds and also thrives in pots. Chip the seeds or soak them in warm water for 24 hours to promote prompt germination. We offer the best seeds or nutlets. Started early the plants bloom freely the first season, and are not difficult to keep over winter.

Choice New Hybrids, 30in. very fine colors mx. Alba grandiflora, large-fl'wd white, beautiful. Roi des Rouges, deep red or scarlet; showy. Nana Compacta, 1ft. fine for pots and beds; mx. Complete Special Mixture of all varieties of Lantana, 5 cts.

$\begin{array}{ll}\text { LISIANTHUS Russelianus, 2ft. large deep purple flowers. } & \text { NICOTIANA glauca, 9ft. glaucous folıge, yellow flowers. }\end{array}$

LINARIA, Kenilworth Ivy, trailer; a hardy perennial, fine OXALIS floribunda, 9in. White; also Rose, sep. or mixed. for baskets and rock-work; thrives in a dense shade and PASSIFLORA alba, vine, flowers large, magnificent. is of easy culture; flowers lilac. Compacta alba, white; Coerulea, exquisite blue, hardy South; very handsome. Globosa, globular, 6in. See page 12.

MANDEVILLEA Suaveolens, a robust shrubby vine, almost hardy, bearing freely large, very fragrant fis; beautiful.

MEDEOLA Asparagoiles, Smilax Vine, a near relative of Asparagus, with very handsome shining foliage; pretty on a pot trellis and fine to cut. A desirable house plant. See eng. Myrtitolia, "Baby" Smilax, small in leaf and vine. MELLANTHUS major, $7 \mathrm{ft}$. Honey Flower, pretty foliage.

MIMOSA pudica, $2 \mathrm{ft}$. Sensitive Plant, lovely foliage and pink

flowers; a good pot plant and fine winter-bloomer. See eng. Spegazzina, Tree Sensitive Plant; shrubby kind.

MEIMULUS Tigrinus, 1ft. Queen's Prize, a very beautiful pot plant; likes moist, sandy soil and partial shade; exquisite large flowers of charming colors. See engraving.

Moschatus, 6in. Musk Plant, fls yellow dotted brown.

MUSA Ensete, oft. Banana Plant, showy tropical foliage. NERIU M Oloander, 10ft. lovely flowering shrub; mixed colors. PELARGONIUM, Fancy and Spotted, large flowers richly marked; called Pansy Geranium. Pkt. contains 3 seeds.

Odier Blotched, large, blotched, handsome. 3 seeds per pkt. Grandiflorum, large flowered, mixed. 3 seeds per pkt.

Hederafolium, Single Ivy-leaved, mixed. 3 seeds per pkt.

Double Ivy-leaved, seeds scarce. 3 seeds per pkt.

Odoratissimum, Apple-scented, fine.

Zonale, Geranium, fine mixed. 15 seeds.

Extra Choice Mixed, seeds scarce. 8 seeds.

Double, newest large-flowered, finest mixed, 7 seeds.

Silver-leaf, scarlet, with white variegated leaves. 3 seeds.

Gold and Bronze-leaved, variegated. 3 seeds per pkt.

Note. We especially recommend our seeds of Zonale Geranium; they will produce fine plants and handsome clusters of bloom. The plants are easily started from seeds. Edulis, blue and white; fruits edible; splendid.

Gracilis, neat graceful plant; flowers white striped blue. Superb speclal mixture of all the above, 5 cts.

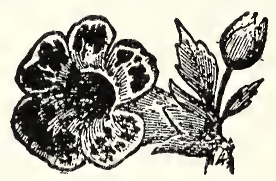

Mimulus, Queen's Prize

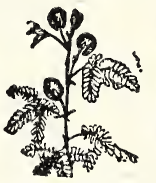

Mimosa pudica

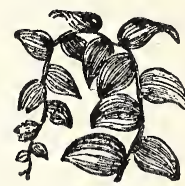

Medeola, Smilax

PETUNIAs. These are among the most useful of flowers for pots or beds. They bloom freely all summer, defying all kinds of weather, and the flowers are charming in color, very showy, revel in any situation, and make the evening air redolent with perfurne. If started in mid-summer the plants elso brighten the sunny
plant window the entire winter. We especially recommend the folplant wing cholce dwarf Petunias for pots and beds:

Rose of Heaven, $1 \mathrm{ft}$. fiery rose, fine for both pots and beds; one of the most beautiful and desirable of Petunias.

Snowball, 1ft. pure white, showing a wealth of lovely bloom.

Norma, 1ft. distinct rich blue with central n hite star.

Erfordia, $1 \mathrm{ft}$. dense, profuse, lovely rose, white throat.

Inimitable, 1ft. a choice mixture of finest spotted sorts.

Complete Special Mixture of the above, 5 cts. See also p. 15.

PHYSIANTHUS albens, vine, white, red-tinged flowers.

PITTOSPORUM undulatum, 6ft. evergreen; white, fragrant flowers in clusters; defies a salt-spray.

POINSETTIA pulcherrima, $3 \mathrm{ft}$. the beautiful popular scarlet Christmas flower. Seedlings started in Spring bloom the next Christmas.

POINCIANA Gillesii, 3ft. a glorious-blooming pot plant. Pulcherrima, $3 \mathrm{ft}$. flowers orange, (Flower Fence).

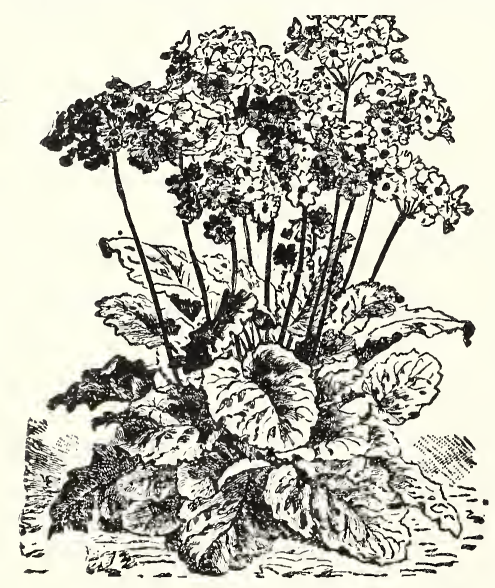

Primula Obconica in bloom

\section{PRIMULA Obconica, Benary's Giant Strain \\ Complete Special Mixture, 5 cts.} DIMULA OBCONICA has been greatly improved since it was introduced from central China some years ago. The plants are now free-blooming, and the flowers so large and full and varied in color that they rival the best of the old Chinese varieties. A windowful of these Primroses in bloom is a glorious spectacle, and never fails to elicit enthusiastic admiration and praise. The plants are as easily grown and oared for as those of Primula Sinensis, and afford just as much pleasure and satisfaction. We offer a very superior strkin of seeds, and send cultural directions with them, which will insure success. Ste eng. GIGANTEA, 1ft Lilac. Apple Blossom, pink. Kermesina, crimson. Lilacina, deep lilac, Salmon Queen, new Sanguinea, deep red. Pure White, fine.

Hamburgia, deep rose.

Coerulea, fine blue.

Rosea, surerb rose.

Fire $C$ ueen, fire red. Comnlete Special Mixtme of Benary's Giant Strainged Giant, Mixed. NOTE. When in Germany at Mr Benary's establishment I was being shown through the greenhouses when a door was opened into a long house of Primroses, each plant bearing many graceful clusters of exquisite big flowers of various fine colors, as large as those of the Chinese Primrose. I did not recognize Primula Obconica in this giant form, and when informed that the plants were of Benary's Improved Giant-flowered Obconica I was amazed and at once became enthusiastic-over its beauty. I am pleased indeed to offer our friends seeds of these grand Primula Obconica direct from Mr. Benary. saved in his greenhouses from his splendid collection of improved varieties, and sunnly the seeds in the separate colors or in mixture. These Primroses cannot be
too highly nratsed. They are more easily grown than Chinege Primroses, and will vield unbounded satiafaction Be sure to order some of these fine Primroses. Geo. W. Park. 


\section{CHINESE PRIMROSE, GIant ringed \\ Complete Special Mixture, 5 cts.}

WV E all agree that the Primroses are the most desirable of all plants for general window culture. They start readily from seeds, come into bloom in a few months, and are sure to bloom freely in the window in winter. Some window gardeners make them a specialty and have a glorious window display of them when all without is bleak and bare and frigid. The Chinese Primrose (see eng.), is simply indescriba'jle in foliage and flowers, and we are delighted to offer seeds of the finest known strain. They are positively unexcelled in quality, and will yield for you the very best results. Full cultural directions are sent with the seeds.

Lady Randolph Churchill, pure white Marquis of Lorne, rose, charming. Blue, lovely flowers, green foliage. Crimson, a rich color of Vilmorin's. Emperor, splendid copper color.

Reddish Magenta, new, fine.

Pale Pink, an exquisite color.

Glittering Red, rich and beautiful.

Soleil d'Empel, pure white, gold eye.

Superb special mixture of all colors.

NOTE. I do not know where nor how to get better seeds of Chinese Primrose than what we offer above. Our seeds were all gaved by a
French Primrose Specialist from his best giant-flowered plants, and from the finest brightest colors. They cannot but delight those who French Primrose Specialist from his best giant-flowered plants, and from the finest brightest colors. They cannot but delight those who
grow them. We challenge comparison with any other strain, as we think we have absolutely the best Primroses that can be produced.
Only 5 cents for a packet of 15 seeds. The seeds germinats in about three weeks. Geo. W. rark.

\section{Other Choice Fringed Chinese Primroses}

Complete Speclal Mixture, 5 cents.

rilicifolia, Fern-leaved, White, Crimson, and Lilac with white margin; separate or in mixture, 5 cents.

Macrophylla (Fernleaved) Gigantea, the magnificent large-

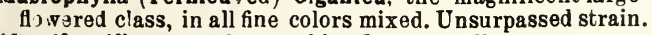
AI ya Magnifica, very large white flowers, yellow eye. Coerula, magnificent light blue.

Duchess Hybrids, variuus rich colors with dark center. Striata, white striped carmine-mauve.

Morgenrote, bea itiful flesh color; rare.

Sedina, brilliant dazzling red; fine.

Defiance, carmine red with brown eye.

Coccinea, rich scarlet, handsomely fringed.

The Duchess, white with big bright carmine center.

Above Choice Chinese Primroses mixed, 5 cents.

Finest Star Chinesc Primroses Complete Special Mixture, 5 cents. Th sse are splendid winter-blooming Primroses of

PRIMULA Floribunda grandiflora, I ft. an improved variety bearing beautiful yellow flowers, an excellent winter-bloomer, rare, showy, and keeping in bloom for a long period. Easily grown from seeds. 5 cents.

Forbesi, $1 \mathrm{ft}$. Baby Primrose, a lovely little Primrose, blooming in three months after sowing; free-blooming, graceful, beautiful; lilac flowers in abundant clusters.

Kewensis, $1 \mathrm{ft}$. a new hybrid; splendid foliage and large golden yellow flowers; a choice winter-bloomer.

Malacoides, $1 \mathrm{ft}$. an enlarged Forbesi, blooms in four months; lilac flowers in large clusters; blooms in summer and winter. REHMANNIA angulata, 2ft. large, free-blooming; rose shades with rich yellow throat spotted purple; half-hardy peren'l. RHODOCHITON volubile, vine, purple-rose flowers with dark crimson corolla; free-blooming, showy.

RHYNCHOSPERMUM Jasminoides, variegated foliage.

RIVINA humilis, $2 \mathrm{ft}$. white flowers and showy scarlet berries. ROCHEA falcats, fine succulent; beautiful scarlet flowers.

SAINTPAULIA ionantha grandiflora, 4in. Usambara Violet; deep blue, long-blooming; seeds very small.

SANTOLINA tomentosa, $1 \mathrm{ft}$. silvery foliage; yellow flowers. SALVIA patens, $3 \mathrm{ft}$. exquisite navy-blue flowers.

SAXIFRAGA sarmentosa, $1 \mathrm{ft}$. very fine for baskets.

SOLANUM capsicastrum, $2 \mathrm{ft}$. small red fruits; for pots.

Pseu locapsicum, $3 \mathrm{ft}$. Jerusalem Chorry; for pots.

Soaforthianum, a lovely blooming vine; blue clusters.

ST ATICE macroohvlla. 2ft. dark blue; fine for pots.

STEPH 1 NOPHYSUM longifolium, 2ft. scarlet; long-blooming STREPTOSOLEN Jamesoni, 4ft. orange flowers in clusters. STEPH ANOTIS floribunda, vine. large, white, sweet flowers. STREPTOCARPUS, Cape Primrose, 1ft. various hybrids mixt. SUTHERLANDIA frutescens, $3 \mathrm{ft}$. scarlet fiowers in racemes SWAINSONIA, $3 \mathrm{ft}$. Pea-like racemes, profuse; mixed sorts. TACSONIA Exoniensis, a lovely vine: red flowers.

TECOY4 Smithii. 6 in. vellow. free and winter-blooming. rETRANEMA. Merican Foxglove, $1 \mathrm{ft}$. pot plant: blue bells THEA Sinensis, $6 \mathrm{ft}$. Tea bearing; white, fragrant. culture than the Fringed varieties. The flowers are plain, of many fine colors, and borne in handsome umbels. If you have never grown Primroses from seeds these are recommended. Some people prefer them to the highly developed kinds.

Snow Star, snow white. |Carnation-flaked, striped. White Queen, large, fine. Light BIue, lovely.

Dark Blue, splendid.

Giant Carmine, bronze leat.
Lord Roberts Star, fiery red.

Pink Star, very pretty.

These fine varieties separate $5 \mathrm{cts}$. or all mixed 5 cts.

\section{Double Chinese Primroses}

Complete Special Mixture. 5 cents.

The Double Chinese Primroses are shony and beautiful pot plants for the window in winter, and we offer choice seeds saved by Kelway that can be depended upon for splendid flowers. We have the follo wing colors: Pure White, Striped, Pale Pink, Bright Red; and Kelways Mixed. Separate or mixed, 5 cents per pack et of 15 seeds.

Minus, 1ft. small orange flowers tinged red; for pots.

Coccineus, small scarlet flowers; pretty pot plant.

TYDAEA Grandiflora, Gesneraceæ, from a splendid collection. VERBENA Citriodora, Lemon Verbena, very sweet foliage.

Veronica, lovely fis of various colors in terminal spikes.

The Best Walls1 owers
Wallflowers are beautiful plants suitable for the garden in a mild climate, or for pots at the severe north. The flowers are large, rich in color and delightfully fragrant, borne in big upright racemes, and very showy. Easily grown from seeds. We offer the finest varieties as follows:

Eastern Queen, clear chamois. Primrose Monarch, fine.

Feltham Larly, red-brown. Vulcan, velvety crimson. Golden Monarch, large, golden White Dame, creamy white. Complete Special Mixture of all these fine Wallflowers, 5 cts.

We also offer the following Window Garden Seeds: Achimenes, finest mixed. Isoloma multiflorum, mixed. Agave Americana, Century pl. Lapageria rosea, vine, waxy 1. Ferns mixed for the window. Mackaya bella, lilac bell fis.

Genista monosperma, white. Palms: Brahea nilamentosa,

Canariensis, yellow, profuse. Pritchardia filamentosa, LaGloxinia Imperialis, Sinningia; tania Borbonica, Chamærops elegant large-fld Emperor mx. excelsa, Phœnix canariensis, Indigofera tinctoria, fls pink. 'Washingtonia; sep. or mixed'

\begin{tabular}{|c|c|c|}
\hline \multicolumn{3}{|c|}{ CAcruses in Variety } \\
\hline Ariocarpus fisssuratus. & Echinocereus Polypus. & Micromeris. \\
\hline Cereus Alacriportanus & Stramineus major. & Uncinata. \\
\hline $\begin{array}{l}\text { Jamacaru. } \\
\text { Giganteus. }\end{array}$ & $\begin{array}{l}\text { Above kinds mixed. } \\
\text { Erhinopsis Fiebrigii. }\end{array}$ & $\begin{array}{l}\text { Above kinds mixed. } \\
\text { Opuntia brasiliensis. }\end{array}$ \\
\hline Tortuogus. & Eyriesil. & Ficus Indicus. \\
\hline Peruvianus. & Lagemanii. & Macrophylla \\
\hline $\begin{array}{l}\text { Above kinds mixed. } \\
\text { Echinocactus Brachy. }\end{array}$ & $\begin{array}{l}\text { Gemm } \\
\text { Multir }\end{array}$ & $\begin{array}{l}\text { Edible sorts mixed. } \\
\text { Opuntie mixture. }\end{array}$ \\
\hline Corniger. & Rose & autumn. \\
\hline Longihamatus. & Oxpgona. & $\begin{array}{l}\text { Phyllocactus ackerma } \\
\text { Crenatus Haageanud }\end{array}$ \\
\hline Oursellianus. & New Hybrids Mixed. & Gloria. \\
\hline Pilosos rosea. & Mamillaria carnes & Jalappa. \\
\hline A bove kinds $m$ & & New large-flwd mis \\
\hline Echi & Heyderi var. & Complete mixture $\mathbf{b}$ c. \\
\hline
\end{tabular}




\section{A PAGE OF GOOD THINS.}

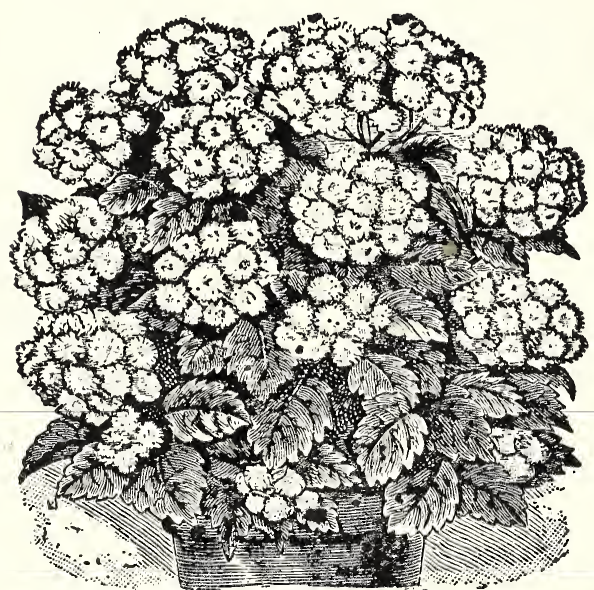

An Everblooming Bedding Plant.

One of the good plants of easy culture that blooms freely from early summer till cold weather is Ageratum. and the improved compact form of Ageratum Imperialis is all that could be desired for a handsome showy bed, or for a border to a bed of taller plants. It grows sfx to eight inches high bearing a mass of big blue clusters, thus forminga sheet of exquisite color throughout the season, There is a whiteflowere 1 variety that is excellant for borders. Both are easily grown from seeds which can be started in a box or hotbed for early plants, or in the garden for later blooming, Per packet of about 300 seeds either color, 5 cts,

\section{A Beautiful Aster.}

A beautiful big Single-flowered Aster that has become very popular in England for a large showy bed and also for cutting for house decoratlon is Southcote Beauty. The flowers are like an immense Ostrich-feather Aster, the petals long and fluffy, and the golden center smail. They come in many different bright colors. and for a big showy autumn bed they can hardly be surpassed. The most attractive of the varieties is Scarlet, and this color I can supply in packets of 200 sesds at $5 \mathrm{cts}$. The plants grow two feet hlgh, branch freely, and bear the flowers on long stems in great profusion. Set $8 \mathrm{in}$. apart. They remain a long time in bloom, and a bed of them makes a glorious display. The bed can be edged with the New Mauve Beauty, the "lovliest color of which the Aster is capable". Scarlet also Mauve or all colors mixed 5 cts.

\section{For a Showy Constant Bed}

If you want a showy bed that will keep bright from early summer till destroyed by frost get a packet of Coxcomb named Glasgow's Prize. The plants grow about 8in. high, each plant forming an immense crimson comb. The combs 1 ti are formed as soon as the plants are a few inches high, and continue to grow and enlarge until twelve inches broad, The massive green foliage covers the bed and makes a rich background for the big

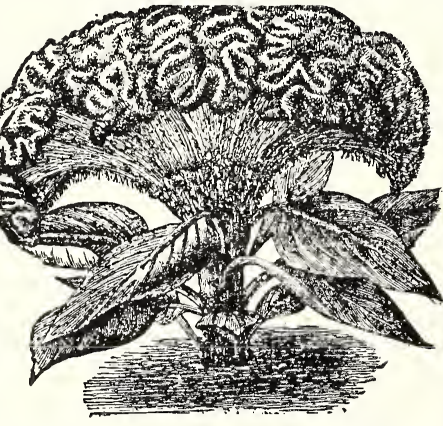
crimson combs. The bed can be bordered with Sweet Alyssum, which is constantly in bloom. Packets of 60 seeds 5 cts.

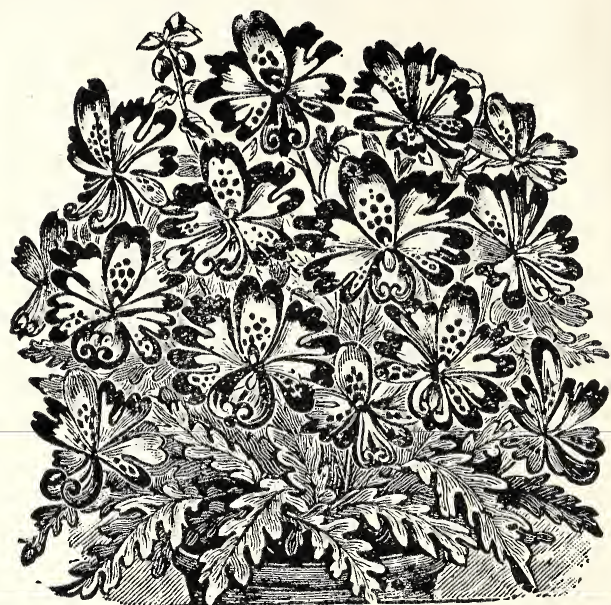

Dr. Badgers Hybrid Schizanthus

Among the many good things offered without description in this Flower Book is Dr. Badgers Large-flowered Schizanthus. I am pleased to offer this splendia strain of Schizanthus, It was developed by Dr, Badgcr from the already improved hybrids of S, grandifforus maximus, ard is extraordinary, being a foot high, of compact pyramidal habit, and bearing a profusion of large flowers in many bright, varied and beautiful colors Grown in masses the plants make a fine display in bods, and in pots they rival the more delicate Wise tonensis. Their surpassing beauty and the ease with which they may be grown recommends this Shizanthus to all who want a chaste, handsome and easily managed annual either for ${ }^{*}$ beds or pots. 100 seeds 5 cts.

* Right here I would call your attention to New Dwarf Hybrids of Shizanthus grandiflorus, dwarf and compact, showing lovely red shades; charming in an out-door bed. Price 5cts Also I can supply seeds of Benary's improved strain of $S$. Wisetonensis--superb long and profuse-blooming hybrids in many splendid shades, excellent pot and market plants, the seeds gathered from carefully selected pot-grown plants. 5cts.

\section{A Glorious Orange Flower.}

Cheiranthus Allioni is perhaps the most attractive of orange-colored flowers for beds or groups, Plants are readily grown from seeds, and if started early will bloom freely throughout summer and autumn,making a blaze of rich orange color that can. not be equalled by any other flower. The plants grow 15 inches high, branching and covering the bed when set 5 inches apart. If sown in Septomber in protected beds and early Spring the pl'nts will

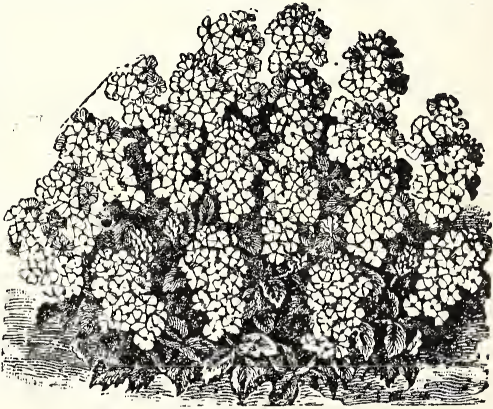

play througho" $t$ the season, The flowers rome in fine clusters at tips of the branches, and can be used for cutting if desircd. A lovely companion for this is Cheiranthus linifolius, which lears lilac-mauve flowers, grows a foot high, and oan be used as a border. It is treated the same way, 40 seeds of either, $5 \mathrm{cts}$. I particuarly recommend these flowers. They are rare, and have a striking appearance when grouped together. 


\section{A Few Helpful Suggestions.}

Y Friends, in such an extended list of flower seeds as you find in this Flower Book it is sometimes perplexing to know just what you shculd order to get the most satisfactory results. For this reason I shall here give a few suggestions that I think may be helpful.

Alyssum Sweet. We all concede this as one of the Centaurea Imperialis. These are known as Royal most beautiful and useful of hardy annuals, and I am pleased to offer the following new varieties: Little Dorrit, 4in., snow white, compact, for beds. Lilac Queen, 5in. pale lilac, upright, dense.

Primrose Queen, 4in. primrose-hue, upright spikes. Minimum, 2in., white, trails, carpets the ground. Anemone, St. Bridgid, The Lily of the Field, improved; large Poppy-like flowers of many colors and lovely variegations. Plants started in April bloon during fall; and in a mild climate during winter. I offer the best strain slowing bi ighest colors. Antirrhinums. My strain of these is unsurpassed. All bear giant flowers, and I offer also Benary's Double-flowered and Smith's Picturatum, both rare and beautiful. See page 5 .

Aster. Kelways New Development, Giant Branching,Decoration and Gargantuan Astersare all surpassingly beautiful. The New Decoration is the last word in Improved Double Asters. All are of huge size, perfect form and double to the centre. Glorious in beds and fine for cutting.

Amberboa Muricata. This is a rare hardy annual sometimes called "Fairy Sweet Sultan". It grows $18 \mathrm{in}$. high, and produees a wealth of lovely blooms on wiry stems, showy in a bed and excellent as cut flowers. The plants are very graceful, bloom for a long period and never fail to call forth expressions of admiration and praise. One of the good annuals that is worthy of general cultivation. The colors are Lavender and Rose, and I can supply both either separate or mixed, pkt. of 40 seeds $5 \mathrm{c}$. Calendula, Ball's Orange, full double, rich orange, the finest of Pot Marigolds. Plants start readily, will grow in any soil or situation, begin to bloom early, and continue till after frost, rivaling Chrysanthemums. Showy in a bed, fine for cutting; has no enemies, a child can grow it. Fine pot plant for winter-blooming. I offer a flrst-class strain. See also page 8 , packet of 50 seeds, $5 \mathrm{cts}$.

Candytuft, Giant Hyacinth-flowered, the largest, most showy and most popular of Candytufts, a hardy annual a foot high, bearing big clusters of pure white flowers forming a sheet of color in a bed. Sow either in early pring or in a mild olimate in autumn. One of the good things that should be in all gardens. Sow where plants are to bloom and thin to $6 \mathrm{in}$. apart, pkt. of 150 seeds, 5 cts.

Carnation, Earliest French Chabaud, Vilmorin's Prize Strain, grown in France. This is the finest of all "Annual" Carnations. The plants are vigorous and bloom in four months from seeds, each plant stooling out and throwing up many stems and showing a mass of huge double flowers, rich and varied in color and making the air redolent with $d$ licions perfume. The plants are hardy, and will do service for several years if the flowers are freely cut;packet of 25 seeds 5cts.

Centaurea Cyanus. Showy, free-blooming hardy annuals, excellent in borders, and unsurpassed for cutting, the flowers last for days. Popularly known as Corn Flowers or Bachelor Buttons. I offer all the fine c lors. Emperor William Double is une of the most exquisite of blue flowers, and a popular florists $f$ ower. You will not regret planting a bed of this flower to have quantities for cutting.

Sweet Sultans. The flowers are much larger than the old-fashioned, and come in a great variety of colors. Easily raised from seeds, and the long-keeping, fringed, sweet-scented flower in many rich colors are fine for cutting, see pg. 8 , pkt 40 seeds $5 \mathrm{c}$.

Chrysanthemum. The Annual Chrysanthemums are splendid garden flowern of easy culture, both single and double. I off or the best kinds, and ask you to turn to page 9 , where they are described and a dwarf Tom Thumb plant shown as a pot-plant. This Tom Thumb is the best for beds or pots. The plants grow about a foot high and are literally covered with bright extremely double golden flowers. It deserves to be better known. 50 seeds $5 \mathrm{cts}$.

Delphinium Tom Thumb. I here offer a very beautiful Chinese Larkspur or Delphinium that forms globular plants a foot high just smothered with charming ultramarine blue flowers, in fancy not unlike little butterflies. It is called Tom Thumb, being the least of the Chinese Larkspurs. For a little bed or border this Larkspur can hardly be equaled. Sown early in spring it will begin to bloom in midsummer and keep up the display for weeks. Sown in autumn the plants will begin to bloom earlier. I am sure this handsome little "Butterfly" will please all who try it; pkt. of 40 seeds 5c. Delphinium Orchid-flow $\epsilon$ ring. A very beautiful Larkspur is D. Sulphureum. Plants grow $6 \mathrm{ft}$. high, branch in tree form, and are literally covered with tho most exquisite orchid-like yellow flowers, surpassing words to describe. This is the only yellowflowered Larkspur known. It is very attractive and very beautiful and its rarity seems strange. The seeds are somewhat tardy in starting, but if sown in autumn the plants will appear in spring and bloom during the season. This Delphinium is a hardy perennia!. Pkt. 5cts.

Digitalis Isabellina, a new Gloxinia flowered Foxglove, charming big drooping golden bells on huge branching spikea. A novelty of rare merit. Packet containing 50 seeds $5 \mathrm{cts}$.

Another Foxglove of still greater merit, a real giant, is the new Shirley Digitalis. A group of this splendid race is glorious. In good soil the plants will raise to the height of nine feet, the central spike covered half its length with the magnificent drooping flowers in all colors, most of them distinctly and charmingly spotted. As the plants grow and bloom they throw out side branches each of which also becomes a wreath of rich flowers. This grand race of Foxeloves was developed by that great and good English horticulturist at his Shirley home, (the same skilful hands that developed the beautiful Shirley Poppy) Rev. W. Wilks. Both of these flowers should be in every flower garden. Each packet containing 100 seeds 5 cts.

Didiscus coerulea, the Blue Lace Flower, has become a favorite among florists who grow cut flowers. It is an annual growing 18in. high, bearing an abundance of lovely blue umbels at the tip of long branches. These clusters last for several days when cut and placed in water and have an exquisite effect in bouquets and designs. Sown in ahed about corn-planting time and thinned to $12 \mathrm{in}$. the plants begin to bloom in July. 5 cts. See page 9 . 
Dianthus Nobilis. A race of the most showy and charming of Annual Pinks is D. Nowilis, the Royal Pinks. Some regard it as the most beautiful of all. The plants are a foot high with dark glaucous foliage and large fringed very double flowers in splendid colors from white to crimson. A bed of these Pinks is always attractive, and the flowers are fine for cutting; bloom till winter. 60 seeds $5 \mathrm{c}$

Echium. I am pleased to offer and recommend three kinds of Echium,plants that belong to the Borage family. They grow two feet high and are showy and beautiful when in bloom. E. Plantagineum has lovely blue flowers; E. Plantagineum album has white flowers; and E. Creticum scarlet flowers. Grown together these Echiums make a fine display, the searlet-flowered being in front. I can also supply seeds of Echium vilgare. These rare annuals, all 15in. high, bloom continuously and deserve to be better known. Packet of 50 seeds separate or mixed, 5cts.

Gaillardia Lorenziana. This is a double-flowered hardy annual, blooming throughout summer and autumn, displaying its flowers even after severe frosts. Plants grow a foot high, the exquisite semiglobular flowers 2in. across, borne on good stems and lasting well when cut, are showy garden flowers. I offer Benary's Special Strain, very superior, mixed, 5cts. Also see page 10.

Gazania Longiscapa. This is a rare new hardy annual that should be popular. Just the flower for beds and pots. Easily grown. Flowers over 2in. across, golden yellow with a brown silvery spotted zone surrounded by a blackish brown ring, see page 11 .

Geum Mrs. Bradshaw. I specially recommend this grand hardy perennial. Started early the plants will bloom the first season. The plants grow $2 \mathrm{ft}$. high and freely produce the most dazzling Geranium-scarlet flowers nearly 3in. across, very showy in a bed and excellent for cutting, as the flowers last a long time in water. Should be a "musthave". Packet of 25 seeds 5 cts.

Godetia. When visiting the big seed gardens in England and Germany I saw nothing more attractive than the fields of Godetia. They were glorious sheets of cclor, which almost dazzled the eyes with their brilliancy. Beds of Godetia were also in public parks and private gardens, and the question arises "why are these beautiful annuals so rarely seen in America?" Perhaps it is because their beauty is not known. But why not try them. I offer, some of the best (see page 11), and will here mention three that grow a foot high and will look well in a ribbon bed: Crimson Glow, rich crimson, Rosamond, vivid rose, and Duchess of Albany, satiny white. The latter is slightly taller than the others. Sow in early spring where plants are to bloom,or sow in bed and transplant to $8 \mathrm{in}$. apart. 75 seeds $5 \mathrm{c}$

Larkspur, Percnnial. This year I offer seeds of Kelway's Gold Medal Perennial Larkspur in mixture. These seeds were saved by Kelway from the finest named kinds, double and single, no cheap ordinary Delphiniums included. Scores of Gold and Silver Medals, Firstclass Certificates and awards of Merit of the Royal Horticultural Society have been accorded for these Glorious Larkspurs. They are simply unapproachable by competitors. Plants grow $7 \mathrm{ft}$. high, branching into numerous spikes gracefnlly set with big butterfly-like flowers of the richest colors and variegations. If cut freely to prevont seeding the plants will bloom throughout the season. Plants are hardy and will last for several years. Packet of 50 seeds 5cts. Be sure to add this to your order.

Linaria. I ask your special attention to the Linarias offered on page 12 . They are all so free-blooming and beautiful that I wonder they are so rare. Just try them. L. Cymballaria is one of the loveliest known plants for a hanging basket or vase, and will thrive in sun or in the most dense shade. Read the offers and add at least two or three Linarias to your order. Packets only 5cts.

Lobelia. The beds and edgings of blue and white Lobelia in Europe are enthusiastically admired by tourists, being masses of exquisite color, and they ought to be better known in America, as the y are easily grown fi om seeds. The new pendulous sorts are unsurpassed for baskets, bracket pots and vases. See page 11 .

Lupinus Hartwegii. This is a splendid hardy annual $2 \mathrm{ft}$. high, branching like a tree and each branch becoming a wreath of lovely, showy sweet-scented flowers. Started early in spring the plants begin to bloom in midsummer and bloom continuously for weeks. They thrive in any soil or situation. The flowers are fine for bouquets. I can supply Dark Blue,Azurc Bluc, White, Rose, sep. or mixed. Marigolds. There is a vast difference in Marigolds, depending upon the quality of the seeds. African Marigolds from inferior seeds are little better than weeds, while from Prize beds they are not unlike Dahlias in size and rich color. The same is more or less true of French Marigolds, which are favorites in most gardens. The little Tagetessignata pumila grows $9 \mathrm{in}$. high and is a glorious mass of bloom in autumn, desirable either in beds or borders. $T$. lucida is also handsome, and deliciously scented. My seeds of all these Marigolds are of the finest quality, grown by specialists. You will find them first-class. Packet 5cts. See page 13.

Nemesias. These are very popular bedding and pot plants in England and are of easy culture. They grow 9in. high, from tuft-like plants smothered with the loveliest flowers of blue, white, pink and scarlet. Sow in a box or bed and transplant $6 \mathrm{in}$. apart. Blue Gem and White Gem are large-flowered hybrids, very fine for beds or edgings. Nana Compacta and Triumph are dwarf improved Strumosa varieties of special value for summer beds or window pots in winter; come in mixed colors. Lilacina is small flowered but very profuse-blooming, as also versicolor which comes in blue, lilac and white. These are among the good things but little known. See page 13.

Pansy, New Apricot, a rare and delicate color not found in any other variety, just introduced by Haage and Schmidt of Germany. It is new and very attractive and recomended for bedding. As yet the seeds are very expensive, but I will sell packets of 25 seeds for $5 \mathrm{cts}$.

Just here I will ask attention to my New Spencer Frilled and Ruffled Giant Pansies offered on page 14 , as well as to the fine strains recommended. I am enabled to sell these at 5cts. per packet only by the great demand I have for them.

Poppy, New Sunbeam. See my offer of these Poppies on page 14. They are perennial, hut bloom the first season if sown early. They belong to the Nudicaul race. The big showy flowers are freely borne on strong stems that issue from the ground and a bed of them is a beautiful sight; pkt. 5cts. 
Petunias, etc. On page $15 \mathrm{I}$ offer the finest Petunias|Verbena. On page 18 you will find offered a superb known, as also of Phlox Drummondii. On page 16 you willfind the very best quality of Double Portulaca offered, the seeds specially grown by Benary of Germany. The flowers are as double as roses and of all colors. On same page you will find description of the New Giant Gloxinia-flowered Salpiglossis, the flowers of which are amazingly rich and beautiful.

Salvias. I offer a splendid collection of Salvias on page 17-annual, biennial and perennial. Salvia coccinnea with fiery scarlet flowers is a fine plant for a large pot;S. Ringens, with large purple flowers and S. Roemeriana with orange-red flowers, also S.Patens with the loveliest of blue flowers are fine for either pots or beds. The showiest in beds, however, is Salvia splendens, one of the grandest of bedding annuals. See note appended to Salvia on page 17 .

Vinca rosea. I call your special attention, too, to Vinca rosea as a bedding plant. It grows a foot high, and will endure heat and drouth better than any other flower I know of. Set 8in. apart the plants become a sheet of exquisite bloom and will remain so until cut down by severe frosts, also a good pot plant for winter blooming; easily grown and easily transplanted. Modestly described on page 17. In a mild climate it will reproduce voluntarily. Scabiosa. A hardy annual of great beauty and usefulness is the New Dwarf Improved Double Largeflowered Scabiosa. The plants are taller and the flowers much larger than those of the common dwarf Scabiosa; admirably adapted for beds and borders, while the long-stemmed flowers are fine for cutting. I offer the leading colors, see page 17 . Ten Weeks Stock. The Improved Double-flowered Ten Weeks Stock may be considered the most desirable of all annuals. Plants are easily started from seeds, grow readily, bloom continuously, while the flowers are large, delicate in texture, come in many exquisite colors, and are deliciously scented. My seeds of these were all saved from pot plants specially treated, and can be depended upon for the finest flowers. I offer the leading kinds in many separate colors or mixed,see p. 17. Virginia Stock, The Virginia Stock is also an annual, but very different, belonging to a different genus. The flowers are small, single, bit of lovely colors and very free-blooming. Besides the varieties offered I can supply Fairy Queen, a new sort that bears beautiful carmine flowers.

collection of Mammoth Verbena, all the finest varieties as well as some of the rare and beautiful species. I would also ask you to consider the New Queen Giant Verbenas on page 36. Verbenas are indispensible garden flowers, and it pays to get the improved kinds. My seeds of these are the best quality and will afford untold pleasure.

Wallflowers are beautiful, very fragrant, easily grown. Do not omit them. See pages 18, 27, 31 and 39 .

Zinnias have been favorite annuals with me since childhood, when only the single-flowered were known. To-day we have not only the miniature or Lilliput double Zinnias, but mammoth-flowered kinds that are not unlike Dahlias in size and beauty. My seeds of Dahlia-flowered Zinnias are direct from the originators of these beautiful supergiant Zinnias and cannot be equalled. Try Zinnia gracillima; grows 1ft. high, branches and shows a mass of baby flowers, double to the centre and dazzling scarlet in color. It makes a grand bed or border. Zinnia Haageana Perfection has similar double flowers, but the petals are narrow, as also the foliage, while the colors and markings are rare and attractive. They deserve a place in every flower garden. See page 18.

\section{Three Splendid Novelties.}

Marigold, Climbing. This most attractive of all Marigolds will grow $15 \mathrm{ft}$. high, the stems covered with little golden protuberances. It branchesfreely, and needs strong support. In autumn it is literally covered with large, full-double flowers, and becomes the most attractive thing in the garden, calling forth' enthusiastic praise from all who see it Pkt. 5c.

Thermopsis Caroliniana. This is another garden novelty of special merit. It grows $3 \mathrm{ft}$. high, becoming a tree-like plant bearing long racemes of pea-like golden flowers. The plants are of easy culture and of such rare beauty that it seems strange it was not introduced and popularized before this. It makes an exceedingly showy bed. Try it; pkt. 5cts.

Crotalaria Juncea. This beautiful annual grows $8 \mathrm{ft}$. high, branching at the top and developing long racemes of large pea-like flowers, golden yellow with brown shading on the standard. On our grounds it is one of the most attractive and enquired-about autumn flowers we have. For years it was grown in English hot-houses as a rare tropical plant, and it is only recently that its merits as a garden plant be came known. It will delight all who try it; pkt. 5cts.

Space will not permit me to speak of Everlastings, Vines, Biennials and Perennials and the choice plants for the Window Garden, but these are more or less recommended in pages 19 to 31, and I hope you will carefully study those pages. Only the best things are offered, and you will find a lot of information crowded in among the descriptions. Please Note: My seeds are all $5 \mathrm{cts}$. a packet, 22 pack$\epsilon$ ts $\$ 1.00,50$ packets $\$ 2.00$. Ask your friends to send with you and make up a club order. I will gladly mail copies of Park's Flower Book to any prospective patrons or to anyone who would appreciate it, whether they wish to buy or not. Let me hear from one and all. GEO. W. PARK, Greenwood, S. C.

Perennials for Beds and Borders. Alyssum Saxatile Continuous-brooming Annuals. Ageratum Sweet Al compactum, Arabis Alpina, Aubrietia, Campanula medium. Carnation, Delphinium, Digitalis, Hollyhock, Hesperis, Leucanthemum, Iberis sempervirens, Papaver Orientalis, Pinks, Saponaria ocymoides, Pyrethrum roseum, Rudbeckia Ne
manii, Silene Orientalis, Sweet William and Wallflower. Pot Plants. The best plants for pots are Abutilon, Begonia, Calceolaria, Cineraria, Carnation,Coleus, Gloxinia,Compact Petunias, Primula Obconica, Malacoides and Sinensis. To these may be added Double Balsam, Browallia, Alonsoa, Asclepias curassavica, Lobelia, Zanziber Balsam and Nemesia. yssnm, Asclepias curassavica, Asperula azurea, Double Balsam, Browallia, Celosia, Gaillardla, Lobelia, Impatiens, Marigolds, Miräbilis, Nasturtium, Pansy,Phlox, Petunia, Portulaca, Scabiosa, Ten Weeks Stıck, Verbena, Vinca, Wallflower, Zinnia, Helichrysum, Luffa, Ipomoea, Maurandya, Thunbergia, Etc

For the Roekery. Abronia,Alyssum saxatile, Arabis, Aubrietia, Campanula Carpa+ica, Iberis Sempervirens, Cerastium biebersteini, Crucianella stylosa, Erysimum pulchellum, Gypsophila muralis, Oxalis, Primula Cashmeriana andRosea grandiflora, Sanvitalia, Saxifrage, Sedum, Tunica, Viola cornuta, Jonopsidium, Leptosiphon and Potentilla. 


\section{Mammoth Queen Verbenas}

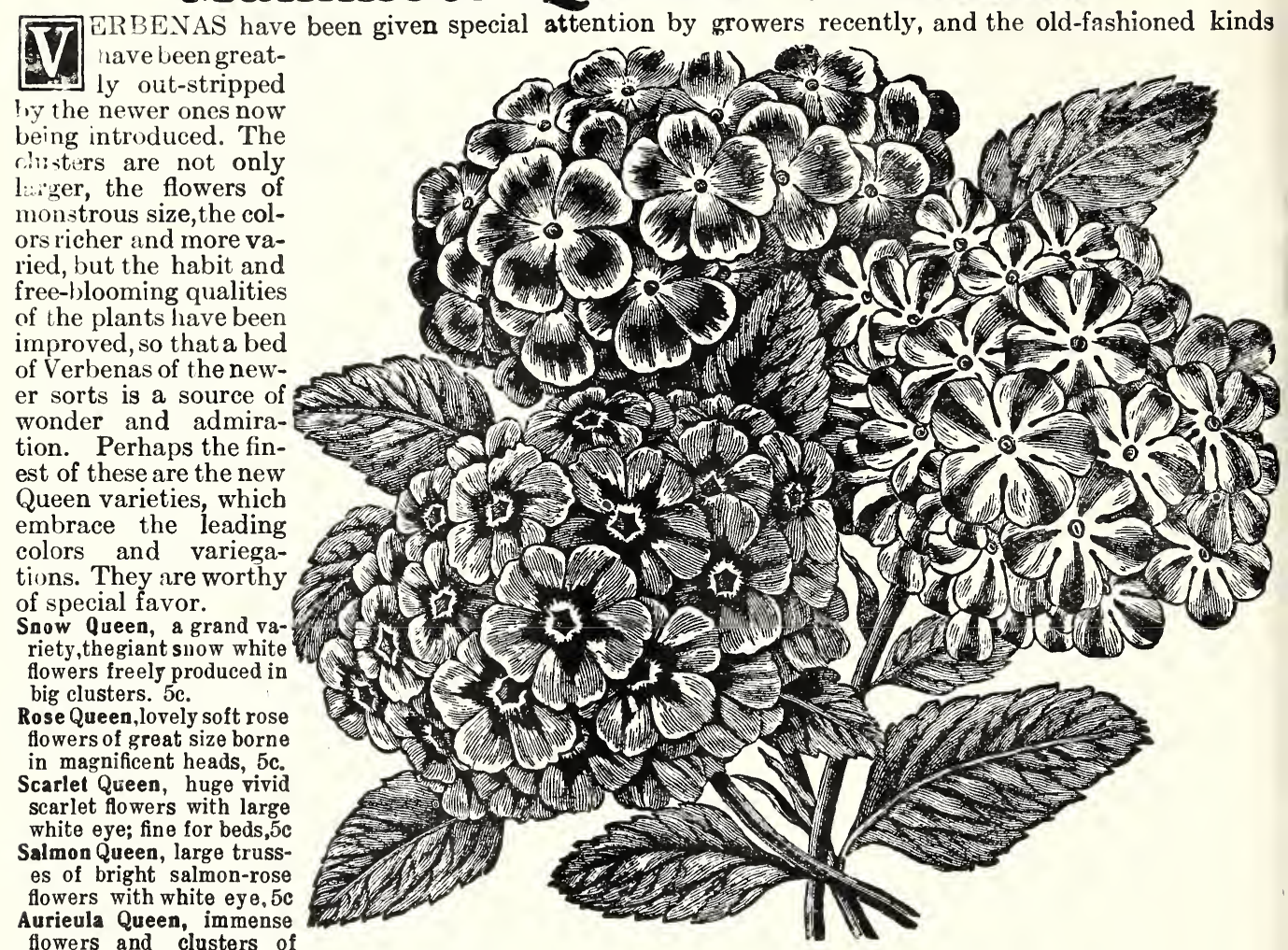

flowers and clusters of

various colors with large distinct eyes, 5cts.

Superb mixture of all the above sorts $5 \mathrm{cts}$.

The seeds of Verbenas usually germinate in less than two weeks, and the plants begin to bloom when quite young. Set $18 \mathrm{in}$. apart they soon cover the bed, and make 2 fine display until winter. They like a sunny situation and good soil.

Some Fine Pot Plants. The choice large-flowked hybrids of Calceolaria and Cineraria are splendid winter-

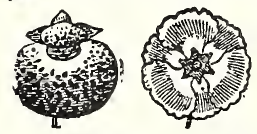

\section{Calceolaria Cineraria} blooming window plants, and easily grown from seeds. See page 28. Our seeds are of Kel ways Perfect Model, and none are better. We have also Benary's Fine German Strain of Calceolarias, and Vilmorin's French Strain. We handle only the best. There is nothing cheap about any of our seeds but the price. We would also call special attention to our Giant Cyclamen, page 29, grown by the famous French firm of Vilmorin, and also Giant Fringed Primrose grown by the same firm, pages 29 and 31. All our seeds are fresh and can be depended upon for vitality as well as quality. Only 5 cents a packet.

Sweet Willams. These are old-fashioned flowers greatly improved, and among the most beautiful of perennials. The flowers are large, well-formed, superbly colored, and are produced in big clusters not unlike the one shown in the little engraving. They are among the most satisfactory of hardy plants for beds and borders, and anyone can grow them. See page 27 . We prefer the exquisite single-flowered kinds, but

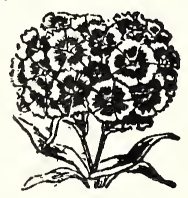

Sweet William can also supply the double ones. When ordering don't forget the Sweet Williams, of which we have extra-quality seeds.

Sweet Peas. Our Spencers are unexcelled. See page 21 . The varieties offered were lately selected by a committee of the National Sweet Pea Society of England as the finest Spenc erSweet Peas of their color. You cannot err in getting them.
Bedding Plants. For beds and borders it is desirable to have plauts that grow about the samc height and bloom freely and continuously for weeks. If you want a spring display you must use hardy annuals that can be sown in autumn, say during August or September, before winter. Among the best for this purpose are the following: Cheiranthus Allioni, Calliopsis Crimson King, Beautv and Grandiflora, Candytuft um-

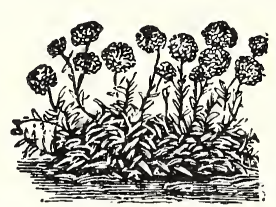
bellata white and Coronaria $\mathrm{Hya}$ cinth fiowered, Double Clarkia, Eschscholtzia (in a mild climate), Erysimum compactum, Dwarf Larkspur, Myosotis victoria, Nemophila, Papaver Umbrosum and Shirley, Saponaria multiflora, Double Silene pendula,etc. Most of these grow from nine inches to a foot or more high, and are generally satisfactory in masses. Avoid crowding, as this often causes the plants to damp off in wet weather,and when close they do uot have room to develop. For Summer aud Autumn Beds you can start seeds in a bed or box and transplant. Use Bedding Antirrhinum, Alyssum, Asters, Balsams, Annual Chrysanthemum, Celosia, Cosmea, Butterlly Del phinium, Chinese Dianthus, Godetia, Gaillardia, Lobelia, Lavatera, Marigolds, Nemesia, Nicotiana, Dwarf Nasturtiums,Pansies, Petunias, Phlox, Pentstemon, Portulaca, Salpiglossls, Salvia, Vinca, Ten Weeks Stock, Soabiosa, Verbena and Zinnia.

Drooping Flowers. For Hanging Baskets and Window Boxes use Sweet Alyssum, Lobelia, Linaria Cymballaria, Balcony Petunias, Schizanthus, Cardiospermum, Maurandya, Thumbergia alata, Smilax, and A sparagus Sprengeri.

$\star \star$ Please Notice, that where a star appears it mdicates something that we consider of special merit worth trying. 


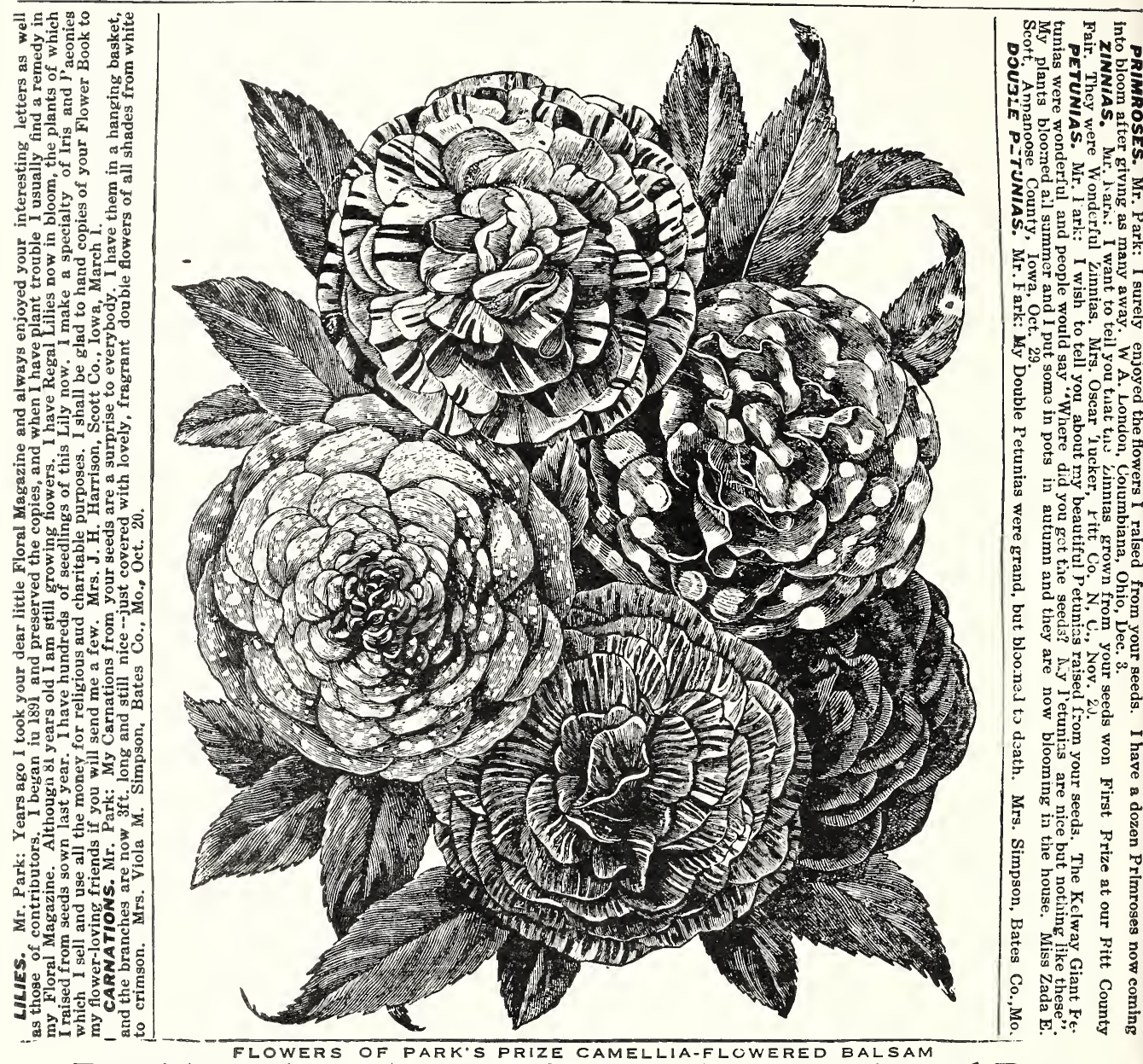

\section{Double Balsams-Best of Annuals for Beds and Pots}

The Improved Camellia-flowered Balsam is one of the most beautiful, showy and satisfactory of annuals either for beds or pots. The plants are readily started, begin blooming early and continue for months. They thrive in sun or shade, and if young plants are started in September and potted they will bloom freely in the window during the winter. The flowers are large,exquisite in form, of a pleasing wax-like texture and show many shades of color from white to rich crimson, as well as striped and spotted. If you grow but a half dozen annuals one should be the Double Balsam. It is indispensable. Packet containing 30 seeds 5 cts.

\section{The New Flowering Bush Balsam}

This is a Double Balsam being introduced from Italy. It is recommended by the introducers as dwarf-habit, free-flowering, of loose growth and blooming abundantly the entire summer. The plants are easily propagated from seeds, not difficult to care for, and as the flowers are not hidden by the foliage they are well suited for beds. Also desirable for pots in the window. The seeds I offer are from France. Colors: White, Lilac-rose, Red, sep. or mixed. Try this Balsam novelty and report to me on its merits

\section{MISCELIANEOUS THINGS}

CATERPILLARS, Scorpiurus, grown as curiosities, The various seed-pods resemble Caterpillars, and are sometimes put in salad as a harmless joke. They are not palatable. We have Large, Small, Striped and Mairy, separate or mixed, 5 cents. MEDICAG0 scutellata, $1 \mathrm{ft}$, yellow fls, snail-like pods, $5 \mathrm{cts}$, GYMNOTHRIX latifolia. 10ft, nobls perennial grass, forms jig clumps; nodding spikes; very ornamental, 5 cents, CENTAUREA Babylonica, $6 \mathrm{ft}$, golden yellow bloom, 5 cents, CYPERUS, Umbrella plant, semi-aquatic; beautiful, 5 cents. PALM. Sabal Palmetto, the hardy Florida Palm, beautiful, $5 \mathrm{c}$ NELUMBIUM s peciosum, large Egyptian Water Lily, mxd, 5 c. NYMPHAEA, Water Lily, large, fragrant, mired 5 cents,

\section{TREE and SHRUB Seeds}

Ailanthus glandula This coronat Apple glandulosa. Dimorphan hirciniand. Philadphus eronart A ristoleds, fine fruit. Arbutus uneda. Akebia quinata. Berberis Jamesoni. Buddleya Lindleyana. Buddleis Magnifica, Calliearpa americana. Calycanthus floridus. Clematis flammula. Paniculata. Viticella. Crategus pyracantha. Cydonia Japonica. Desmodium Japonicum
Deutzia crenata fl. pl.
Diospyros Virginiana. Philadelphus grend. \begin{tabular}{l|l} 
Euonymus fimbriatus. & Photinia serrulata. \\
Exochorda grandiflora & Quercus n ecrccerra, \\
Fraxinus Excelsa pen. & Phellos. A Jba. Mixed
\end{tabular} rraxinus Excelsa pen. Hibiscus Syriacus fl. $l$. Pibes aureum. Hibiscus Syriacus fl.rl. Pibes aureum. Liquidamber styracifl. Pobinia incisa. Liquidamber styracifl. Pobinia incisa.
Posa Rugosa. Lespedeza bicolor. $\quad \begin{aligned} & \text { Posa Rugosa. } \\ & \text { Pubus Idaeus mixed }\end{aligned}$ Magnolia grandiflora: $\begin{aligned} & \text { Schinus molle. } \\ & \text { Sophora Japonica }\end{aligned}$ Nyssa sylvatica. Paeonia arborea. Staphylea pinnata. Pauluwnia Iinperialis. Tamarix gallica. Lonicera tartarica rose Pubus Idaeus mixed 


\section{Choice Things not in General List}

Antirrhinum New English Compact, fine bedding|Hcsperis, Sweet Rocket, new dwarf white, also purvarieties developed by an English specialist,splendid, see page 40 , $5 \mathrm{cts}$.

Kelway's Up-to-date, uniform medium height, large flowers and magnificent colors; extra, mixed 5c.

Kelway's Choicest, Large-flowered, saved from finest named sorts, none better, mixed, $5 \mathrm{cts}$.

Fairy Tale, a novelty of superior merit; flowers $2 \mathrm{in}$. across, exquisite salmon rose, 5 cts.

Brilliant Rose, pure dazzling rose, showy in beds and fine for cutting, $5 \mathrm{cts}$.

Aster, New Soutlicote Beauty, a grand single Aster for beds, pure white, page 32 .

Mauve Beauty, a magnificent new color, $5 c$.

California Giant,' hu ge flowers, very double, $5 \mathrm{cts}$. Everlasting, flesh color, double, form of Helichryssum, keeps its shape and color when dried.

Sunshine, new, 2ft. branching, flowers 5in. across, quilled center, surrounded by white florets and a circle of curled outer petals of various colors. Kelways Glare of the Garden, 1ft. dazzling red single-flowered, glorious in beds, showy in pots, rich in boquets or vases. 50 seeds 5 cts.

Alyssum Cream yellow, new, from France,splendid. Balsam, New Flowering Bush, a new race from Italy. Fine for borders. See page 38 .

Cosmea F airy Queen, new, $2 \frac{1}{2} \mathrm{ft}$., begins to bloom in July and continues throughout the season; the plants 'branch and bear an abundance of lovely big carmine-rose flowers; extra, 5 cts.

Clarkia, Double Scarlet Queen, Double Pure White, Apple-blossom, Striped, Integripetala alba, Marginata, Kermesina and Pulcherrima alba plena, see Title page and page 9. Sep. or mixed 5cts.

Cynoglossum Blue Perfection, 3ft., a much improved C. Amabile; bears beautiful big sprays of rich blue forget-me-not flowers during early summer; a fine novelty, 5 cts.

Delphinium, Barr's Full Blue and Gentian Blue, 6ft, Magnificent Perennial Larkspur, hardy, choice.

Dahlia, Coltness Hybrids, 18in. single, free-blooming, finest colors.

Dianthus Allwoodi, entirely new; a cross between Pink and Carnation; extremely floriferous; 75 per cent fine double flowers of almost every color; perpetual flowering. Pedigree Strain.

Erysimum linifolium, 9in. compact, becomes a mass of lovely clear mauve flowers, fine for rockeries and small beds.

Eschscholtzia, Kelways New Rainbow Strain, largeflowered, showing many new shades, as soft pink, scarlet, chrome, copper-red, c
royal purple, splendid mixture.

Gaillardia Grandiflora Dazzler, new, large flowers up to 5in. across, bright golden yellow with rich maroon-red centre.

Kelways Prize Hybrids, a grand new improved strain of hardy Gaillardia. Enormous flowers and stout habit. Award many medals and certificatesfor superior merit. The finest Gaillardias known.

Godetia Azaleiflora Cornelia, lovely satin-rose; a fine novelty.

Hollyhock Exquisite, a new race bearing large double fringed flowers with white margin and blotches of various colors.

ple; fine for beds, sep. or mixed 5cts.

Iris California, a new race, blooms first year.

Lavatera Loveliness, pink, very handsome. Award of merit Royal Hort. Society.

Lilium Regale, bulbs bloom second season.

Lupinus, Vis Prize Hybrids, mixture of new shades.

Meconopsis Baileyii, from China, the finest recent novelty $3 \mathrm{ft}$, glorious big sky-blue poppy-like flowers with golden anthers. First-class certificate from Royal Horticultural Society; splendid.

Mimulus Tigrinus Grandiflorus, Queen's Prize, an unsurpassed strain grown in Holland; very large, elegantly spotted flowers; fine for pots or beds 5c.

Mignonette Orange Queen, monstrous spikes, beautifulorange red,richly scented; the finest Mignette.

My osotis oblongata perfecta, clusters of lovely blue forget-me-nots on long stems; fine for winterblooming, when sown in June; splendid.

Nasturtium Improved Lilliput, globular compact plants literally smothered with small blooms of many fine colors and variegations, $5 \mathrm{cts}$.

Oenothera trichocalyx, 18in, bearing large pure white flowers with golden anthers, stays open all day, A grand new Evening Primrose.

Ostrowskia magnifica, $4 \mathrm{ft}$, rare,giant azure bells. Pansy, Rogglis Improved Giant Strain, see page 37. Kelways Blue Boy, a large-flowered Pansy of superb shape and of the most exquisite ultramarine blue color. A Kelway specialty of high merit. The finest Pansy of its color.

Petunia,Benary's Giant Quadricolor, fringed, large tigred throat, pink, veined purple with spatulate, golden markings, finest of Giant Petunias 5cts. $\mid$

Peresia multiflora, $3 \mathrm{ft}$, new biennial, branches, bear ing freely star-shaped light blue flowers, 5 cts.

Poppy, New Shirley Picotee, rare and beautiful 5c. Double Feathered, 3ft, great feather-balls.

Barr's Irresistable, $2 \mathrm{ft}$, hardy annual with fringed double flowers 5in across; colors range from bright rose to blush and salmon, with large white center. Primula veris, Munstead Strain, the best hardy Primroses; mixed, $5 \mathrm{cts}$.

Pyrethrum large-flowered, 2ft, a grand perennial for beds and bordcrs; colors from white to deep red.

Double from choicest double flowers, raised by a Holland specialist. These are as showy and useful as asters; splendid colors, 5cts.

Rhodanthe, one of the loveliest everlasting flowers, easily grown and free-blooming, the flowers showy. Salvia Splendens violacea, Maroon Prince, very deep violet, attractive, 5 cts.

Senecio tanguticus, a herbaceous perennial $7 \mathrm{ft}$. high with dense panicles of golden bloom. 5cts.

Sweet William, annual, blooming first season. Fine clusters, rich colors and variegations, showy;plants endure the winter and bloom freely the next year.

Tithonia speciosa, $7 \mathrm{ft}$, flowers large, orange-red, very freely produced;imposing for tall groups.

Tradescantia virginica, a splendid blue-flowered perennial, not difficult to grow. 5cts.

Verhena, New Queen Mammoth, see page 36.

Wallflower, New Double Annual; 2ft, tree-like, bearing large double sweet flowers of many rich colo:s. Double Dwarf Branching, 1ft. splendid for beds; white, yellow, brown and violet mixed, 5 cts. 


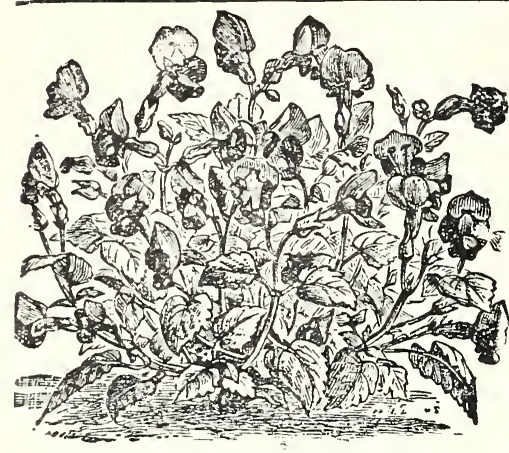

Torenia Fournieri, a charming pot plant.

\section{TORENIA, a lovely Pot Plant}

7 LOVELY and showy flowering plant for pots and heds A is Torenia Fournieri. At a little distance it has the appearance of a fine Pansy, the towers showing a rariegation ark rich blue, with golden throat. Plants are easily grown from seeds, and are bushy and fret-klooning. T. Bailloni is also handsome, the flowers bright golden yellow, with deep red throat. Both of these plants like light rich soil. Fine for the window or market. We offer Fournieri, Blue and Fournieri White; and Bailloni, yellow; separate or mixed, 5 cts.

Thunbergia coccinea, vine; scarlet flowers; fine for pots.

Azurea Grandiflora, robust vine; charming large fiowers; azure blue.

Fragrans, White, fragrant flowers; free-blooming.

Gibsoni, large orange flowers; free-blooming, beautiful.

Seeds of above Thunbergias are very scarce; we can put only 3 in a pkt. THUNBERGIA alata, (See page 22), an easily-grown. free-growing, freeblooming vine for either garden or house; fine winter-bloomer in pots,

\section{The Glorious New Climbing Marigold.}
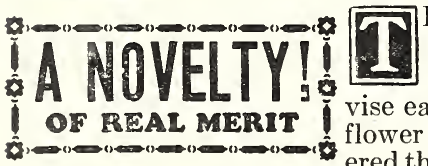

HIS splendid novelty was offered for the tirst cime last season, and although our stock of seeds was large it was exhausted before the season was over. I hope to supply all my friends this season, but would advise early orders, as I may not have enough this season to go around. It is a flower of real merit, growing $15 \mathrm{ft}$. high under favorable conditions, and covered throughout autumn with big showy double flowers. It is something everyone can grow, and something that will cause a sensation in your flower-loving community. Packet of 15 seeds 5cts. Only one pkt. to a person. Its a real novelty of merit, and is sure to delight all who grow it.

\section{Choice Seeds Omitted from the General List}

\section{Blooming the First Season}

Aster, New Mammoth White, $3 \mathrm{ft}$. huge blooms.

Cardinal, $2 \mathrm{ft}$. brilliant scarlet, branching.

Kelway's Victoria, 2ft. large, double, fine; mixed.

Kelway's Glare of the Garden, 18in. red, for beds. Gilia, 1ft. Achilleifolia mixed; Laciniata lavender,

Linifolia white, Nivalis white, Tricolor white, vio-

let and rose mixed, Dwarf or Tall mixed,All mixed. Iris Pseudo-acorus, 2ft. Water Flag, golden flowers. Scutellaria baicalensis, 18in, blue, for beds or cutting. Perennials

Adonis Vernalis, 1ft. golden yellow flowers in tufts. Anemone Japonica, $2 \mathrm{ft}$, white, rose, mixed; lovely fls. Doronicum Caucasicum, $2 \mathrm{ft}$. showy golden flowers. Gardenia, 8ft. Cape Jesmine, white, sweet scented. Ipomopsis elegans, 3ft. Erect Cypress, scarlet, etc.

Cinerarias. Dear Mr. Park: My Cinerarias from your seeds are doing wonderfully well. I am watching for aphides which often attack Cinerarias, My windows are now a beautiful sight, filled with blooming plants raised from your seeds of last spring. Some Begonia seeds left over I sowed this spring and the little pIants are almost ready to transplant. This spring I sent to another seed company for a packet of Begonia, and not even one seed came up. Perhaps we have no faith in any but Park's Seeds. Please do not run off and leave us again. M. N. Eınerson, Hillsborough Co., N. H., April 25.

NOTE. I have been in my present occupation for 60 years, and am still young and active. Dealing with flower-loving people is the most in a beautlful home among genial, refined and intelligent people. have no desire to go elsewherr or change my life work until 1 am callall expect to make. I hope, however, to faithfully serve my friends for many years to come. Geo. W. Park.

ASCLEPIAS. Dear Mr. Park: One of the pretty things I had from your seed; last spring vas Asclepias curassavlea. 1 took up three of the plants and have them in the house and they are formine buds to bloom and thriving, although we have gas and a hot-air furnace. is handsom? and my friends are much interested in it. I am pleas $\mathrm{d}$ with my success in sowing your seeds, From one nacket of Canterbury also raised 20 plants of Oriental Poppy, but lost them in transplanting. Mrs. Geo. Horn، Adams Co.. Neb., Dec. 1 n، 1928

NAMES. Kindly send names of five flower-loving friends who would appreciate Park's Flower Book.
Sempervivum, Irouse Leek, pretty; seeds fine.

Solidago, $3 \mathrm{ft}$. Golden Rod ,splendid varieties;mixed. Shrubs and Trees

Clethra Alnifolia, 2ft. pretty, very fragrant flowers. Cytisus laburnum, $4 \mathrm{ft}$. golden fls. in long racemes. Euonymus fimbriatus, 6ft. fimbriated pretty.

Magnolia Soulangeana, 15ft. Tulip-like purple fls. Ribes Gooseberry, 2ft. large-fruited, mixed.

Robinia Paeudacacia, 40ft. Black Locust, splendid, fragrant flowers.

Robinia Viscosa, rose colored racemes, beautiful. Symphoricarpus Vulgaris, 3ft. Coral Berry, fine.

Tilia argentea pendula, $40 \mathrm{ft}$. the beautiful lime tree. Vitis Coignetiae, Crimson Glory Vine, handsome.

Xanthocerus sorbifolia, 12ft. Hyacinth Tree, handsome white flowers.

Aster, Kelways New Decoration is perhaps the largest and finest Double Aster in cultivation. It is of immense size, double to the center, and may be had in all the leading colors. The plants grow $3 \mathrm{ft}$. high, branch and bloom freely, and the flowers can be cut with leafy stems $2 \mathrm{ft}$. long. I can supply the seeds in Carmine-Rose, Purple. Light Blue, Crimson, Lavender, White, Bright Rose, Peach, Flesh Pink and mixed. These New Asters will be a revelation to those who know only the older varieties. Only 5 cts. a pkt., 50 seeds.

Antirrhinum, New Bedding. I offer these new Snapdragons in the following colors: Bright Rose, Dark Crimson, Light Terra Cotta,Orange, Scarlet, Pale Pink and White also in Complete mixture. The plants are dwarf, bushy, about $10 \mathrm{in}$. high, and exceedingly free-blooming, the flowers being large, showy and fragrant. They have become very popular for beds in England. and will doultless do well in A rerica. My seeds are direct from the English growers. Sep. or mixed.

A Closing Wored. My Flower-loving Friends: I $a^{+}$cipate the pIeasure, of hearing from you, one and all this spring: and when making up your order ask your neighbors to club with you. This is a favor 1 shall appreriate. Also ask for my Spring Pulb List. My Fall List will be mailed to every patron later. My Flower Book is free to your friends; and when ordering name three
or four friends who buy seeds, and would appreciate the Book. Awaiting your favors, and,promising prompt and fsithful attention I remain GEO. W. PAKK, Greenwood, S. C. 